\title{
47. PALEOMAGNETIC CONSTRAINTS ON TONGA ARC TECTONIC ROTATION FROM SEDIMENTS DRILLED AT SITES 840 AND $841^{1}$
}

\author{
William W. Sager, ${ }^{2}$ Christopher J. MacLeod,${ }^{3}$ and Niels Abrahamsen ${ }^{4}$
}

\begin{abstract}
The geometry of the Tonga Arc implies that it has rotated approximately $17^{\circ}$ clockwise away from the Lau Ridge as the Lau Basin formed in between. Questions have arisen about the timing of the opening, whether the arc behaved rigidly, and whether the opening occurred instead from motion of the Lau Ridge, the remanent arc. We undertook to address these questions by taking paleomagnetic samples from sediment cores drilled on the Tonga Arc at Sites 840 and 841, orienting the samples in azimuth, and comparing the paleodeclinations to expected directions. Advanced hydraulic piston corer (APC) cores from Holes $840 \mathrm{C}$ and $841 \mathrm{~A}$ were oriented during drilling with a tool based on a magnetic compass and attached to the core barrel. Samples from Hole 841B were drilled with a rotary core barrel (RCB) and therefore are azimuthally unoriented. They were oriented by identifying faults and dipping beds in the core and aligning them with the same features in the Formation MicroScanner (FMS) wireline logs, which were themselves oriented with a three-axis magnetometer in the FMS tool. The best results came from the APC cores, which yielded a mean pole at $-69.0^{\circ} \mathrm{S}, 112.2^{\circ} \mathrm{E}$ for an age of $4 \mathrm{Ma}$. This pole implies a declination anomaly of $20.8^{\circ} \pm 12.6^{\circ}(95 \%$ confidence limit), which appears to have occurred by tectonic rotation of the Tonga Arc. This value is almost exactly that expected from the geometry of the arc and implies that it did indeed rotate clockwise as a rigid body. The large uncertainty in azimuth results from core orientation errors, which have an average standard deviation of $18.6^{\circ}$. The youngest cores used to calculate the APC pole contain sediments deposited during Subchron $2 \mathrm{~A}(2.48-3.40 \mathrm{Ma})$, and their declinations are indistinguishable from the others. This observation suggests that most of the rotation occurred after their deposition; this conclusion must be treated with caution, however, because of the large azimuthal orientation errors. Poles from late and early Miocene sediments of Hole 841B are more difficult to interpret. Samples from this hole are mostly normal in polarity, fail a reversal test, and yield poles that suggest that the normal-polarity directions may be a recent overprint. Late Miocene reversed-polarity samples may be unaffected by this overprint; if so, they imply a declination anomaly of $51.1^{\circ} \pm 11.5^{\circ}$. This observation may indicate that, for older sediments, Tonga forearc rotations are larger than expected.
\end{abstract}

\section{INTRODUCTION}

The Lau Basin is an active backarc basin located in the southwestern Pacific between the Tonga Island Arc and the Lau Ridge (Fig. 1). Geophysical data (shallow bathymetry, thin sediment cover, high acoustic backscatter, high heat flow, seismicity, and young magnetic anomaly lineations) and geologic samples (fresh MORB-like basalts) attest to the recent occurrence of a process akin to seafloor spreading in the basin (Karig, 1970; Sclater et al., 1972; Hawkins, 1974; Hamburger and Isaacs, 1988; Parson et al., 1990). Apparently, during Miocene time the Tonga and Lau ridges were combined as a single island arc, but subsequently the Lau Basin opened between the two.

Although the Lau Basin and environs have been extensively studied, a number of questions about its tectonic evolution remain unanswered. When did the opening begin? Did the Tonga Arc rotate clockwise away from a relatively fixed Lau Ridge, as suggested by geometry? Can the opening be described by a rigid rotation?

The timing of the opening is uncertain. Magnetic lineations have been identified in the basin, but because they are unclear, these anomalies have been interpreted variously. Estimates for the time of opening range from about 2.5 to $5.9 \mathrm{Ma}$ (Weissel, 1977; Malahoff, Feden, and Fleming, 1982; Kroenke, 1984; Malahoff et al., in press). Moreover, initial drilling results from Leg 135 indicate that the opening of the basin may have occurred in two stages: a period of slow extension, from late Miocene to about $2.5 \mathrm{Ma}$, followed by seafloor spreading and rapid opening (Parson, Hawkins, Allan, et al., 1992).

\footnotetext{
${ }^{1}$ Hawkins, J., Parson, L., Allan, J., et al., 1994. Proc. ODP, Sci. Results, 135: College Station, TX (Ocean Drilling Program).

${ }^{2}$ Departments of Oceanography, Geophysics, and Geodynamics Research Institute, Texas A\&M University, College Station, TX 77843, U.S.A

${ }^{3}$ Institute of Oceanographic Sciences, Deacon Laboratory, Wormley, Surrey, GU8 5UB, United Kingdom.

${ }^{4}$ Geophysical Laboratory, Aarhus University, Finlandsgade 8, DK-8200, Aarhus N, Denmark.
}

The Lau and Tonga ridges form a tilted "V", pointed southward, with the Lau Basin in the middle (Fig. 1). The western side of the Tonga Arc is relatively linear and has an azimuth of $\mathrm{N} 21^{\circ} \mathrm{E}$; the east side of the Lau Ridge is less so, but the southern part has an azimuth of about $\mathrm{N} 4^{\circ} \mathrm{E}$. This configuration implies that the basin has not opened uniformly. On the one hand, the Tonga and Lau ridges may have rotated relative to one another by about $17^{\circ}$ around an Euler pole located near the junction of the two trends (Fig. 1) at $28.5^{\circ} \mathrm{S}, 178.7^{\circ} \mathrm{W}$. Most authors have favored a rigid rotation for the opening of the basin (Weissel, 1977; Malahoff, Feden, and Fleming, 1982; Auzende et al., 1988). An alternative explanation is that seafloor spreading in the basin could have started in the north and progressed southward, "unzipping" the two ridges. This would imply that the Tonga Arc and Lau Ridge did not separate by simple rigid-body rotation.

To investigate the tectonic rotation of the Tonga Arc, we studied the paleomagnetism of sediments drilled during Ocean Drilling Program (ODP) Leg 135 on the Tonga Arc at Sites 840 and 841 . The idea was to calculate paleomagnetic poles for the Tonga Arc and to compare them with poles from the Indo-Australian Plate, to which the Lau Ridge has been attached since Oligocene time when spreading ceased in the South Fiji Basin (Watts et al., 1977). Because the pole of rotation for the opening of the Lau Basin is nearby, no significant differences in paleomagnetic inclinations are expected. Instead, the rotation should appear as a difference in paleomagnetic declinations. Paleodeclination data are difficult to extract from ODP cores because most have an arbitrary azimuthal orientation. Attempts to orient samples from ODP cores fall into three categories: (1) APC cores oriented with a compass tool, (2) samples reoriented by assuming that a normal-polarity overprint on the cores was acquired during the Brunhes Chron and points to north, and (3) orientation of samples relative to azimuthally oriented FMS wireline logs. On Leg 135, oriented APC cores were drilled from the Tonga Arc at Sites 840 and 841 . Furthermore, FMS logs were obtained at both sites. Consequently, we used Methods 1 and 3 to determine Tonga Ridge paleomagnetic poles. 


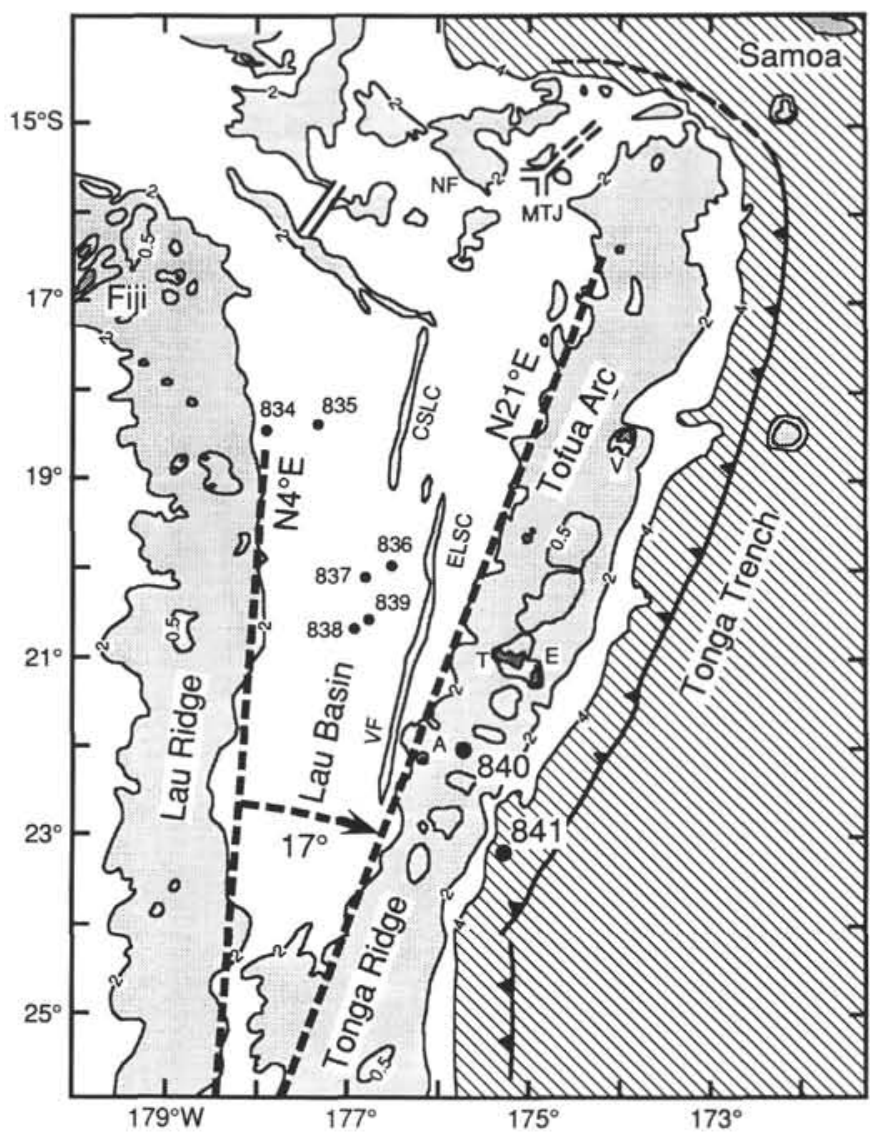

Figure 1. Map showing location of Leg 135 sites and generalized bathymetry of Tonga Arc, Lau Basin, and Lau Ridge. Heavy dashed lines show trends of western Tonga Ridge and eastern Lau Ridge; the difference in azimuths is $17^{\circ}$. Islands include Tongatapu (T), 'Eua (E), Vava'u (V), 'Ata (A), and Niuafo'ou (NF). CSLC = Central Lau Spreading Center, ELSC $=$ Eastern Lau Spreading Center, VF $=$ Valu Fa Ridge, and MTJ = Mangatolu Triple Junction. Contour interval in kilometers. (Modified from Parson, Hawkins, Allan, et al., 1992).

\section{Previous Paleomagnetic Studies}

Few paleomagnetic studies have been done in the islands of the southwestern Pacific and most of these have focused on the island arcs of the New Hebrides (Falvey, 1978) and Solomons (Musgrave, 1986; 1990). The Fijian island of Viti Levu has also been studied (Tarling, 1967; James and Falvey, 1978; Malahoff, Hammond, et al., 1982), and a counterclockwise rotation of $21^{\circ}$ since $4 \mathrm{Ma}$ and as much as $70^{\circ}$ for late Miocene time has been documented. This rotation is thought to be localized in the region of Fiji and to be related to spreading in the North Fiji Basin (Malahoff, Feden, and Fleming, 1982; Auzende et al., 1988). It is not known how far to the south, down the Lau Ridge, that the Fiji islands rotation extends, but the change in the trend of the ridge at $21^{\circ} \mathrm{S}$ may be related.

\section{Leg 135 Tonga Arc Sites}

Drilling was undertaken at two sites (840 and 841) on the Tonga Ridge during Leg 135. Site 840 is located at a water depth of $754 \mathrm{~m}$ on the summit of the shallow carbonate platform of the Tonga Ridge, $45 \mathrm{~km}$ east-northeast of 'Ata Island (Fig. 1). After an abortive attempt at piston coring, Hole $840 \mathrm{~B}$ was rotary cored to a depth of $597.3 \mathrm{mbsf}$, recovering sediments as old as late Miocene. Although the borehole was imaged with the FMS log, few features could be reliably oriented.
Faults were not common and the dips of sedimentary strata were typically only $2^{\circ}-3^{\circ}$ (Parson, Hawkins, Allan, et al., 1992), whereas dips in excess of $5^{\circ}$ are necessary for reliable orientation (MacLeod et al., 1992; MacLeod, this volume).

Hole $840 \mathrm{C}$ was drilled with the APC in depth intervals where soft sediments were encountered in drilling Hole 840B. In all, 13 APC cores were drilled, 11 of them oriented with the Eastman-Whipstock multishot tool. Recovered sediments typically consisted of ashy nannofossil ooze layers within massive beds of unconsolidated vitric ash (Parson, Hawkins, Allan, et al., 1992). Of $74.8 \mathrm{~m}$ of core recovered from Hole $840 \mathrm{C}$, only $10.7 \mathrm{~m}$ consisted of nannofossil ooze. Moreover, only Cores $135-840 \mathrm{C}-3 \mathrm{H}$ through $-7 \mathrm{H}$ contained more than $0.5 \mathrm{~m}$ of nannofossil ooze. Dating of these sediments was mainly by microfossils; however, shipboard paleomagnetic measurements showed that most Hole $840 \mathrm{C}$ samples are normally polarized and this was interpreted as an indication that they were deposited during the Gauss polarity epoch (Subchron 2A) during the late Pliocene (Parson, Hawkins, Allan, et al., 1992). Biostratigraphic markers indicate a sedimentation rate of approximately 39 m/m.y. (Parson, Hawkins, Allan, et al., 1992).

Site 841 is located at a water depth of $4810 \mathrm{~m}$ on the Tonga forearc, $140 \mathrm{~km}$ south of Site 840 (Fig. 1). Hole $841 \mathrm{~A}$ used a combination of the APC and extended core barrel (XCB) to drill to a depth of 186.6 mbsf, bottoming in late Miocene vitric siltstone and sandstone. The upper part of the hole contained barren clays with thin ash interbeds. From this section, four oriented APC cores were obtained (Parson, Hawkins, Allan, et al., 1992). Dating of these cores was primarily by magnetic stratigraphy because no diagnostic microfossils were found. Although the magnetic stratigraphy was hampered by a pervasive drill-string overprint that was impossible to remove completely during shipboard analyses, paleomagnetic results suggest the sediments in the oriented cores were deposited during early and late Pliocene at rates of about $8 \mathrm{~m} / \mathrm{m} . \mathrm{y}$. (Parson, Hawkins, Allan, et al., 1992).

Hole $841 \mathrm{~B}$ penetrated to a depth of 834.2 mbsf using the RCB. The sediments recovered from this hole consisted mainly of vitric sand- stone and siltstone, but basalt, andesite, rhyolite, and carbonates were also encountered. At the bottom of the hole, Eocene carbonates were cored overlying rhyolites of unknown age (Parson, Hawkins, Allan, et al., 1992). Tectonism was clearly a major component of the geologic history of sediments from Hole $841 \mathrm{~B}$. The hole passed through two significant normal fault zones and several minor faults (Parson, Hawkins, Allan, et al., 1992). One of the large faults, at a depth of 449 mbsf, separates late and early Miocene sediments. The other, at a depth of 606 mbsf, separates the Eocene calcareous volcanic sandstone from the underlying rhyolite. Microfaults are common in Hole $841 \mathrm{~B}$ sediments and tilting of the strata increases downhole to angles in excess of $45^{\circ}$ (MacLeod, this volume). Hydrothermal alteration was noted in many cores and appears to have been most pervasive below the major fault at 449 mbsf (Parson, Hawkins, Allan, et al., 1992). Dating for the sediments of Hole $841 \mathrm{~B}$ was principally accomplished by biostratigraphy aided with magnetic stratigraphy. Sedimentation rates of 35-160 m/m.y. were found in the sections sampled for paleomagnetic study (Parson, Hawkins, Allan, et al., 1992).

\section{METHODS}

Samples were taken from the split faces of cores from Holes $840 \mathrm{C}$, $841 \mathrm{~A}$, and $841 \mathrm{~B}$. Soft sediments in APC cores from Holes $840 \mathrm{C}$ and $841 \mathrm{~A}$ were cut with a spatula and placed into $7-\mathrm{cm}^{3}$ plastic boxes. More indurated sediments in the RCB cores from Hole 841B were sampled either by cutting $10-\mathrm{cm}^{3}$ cubes with a two-bladed rock saw or drilling $2.5-\mathrm{cm}$ diameter cylindrical minicores of about the same volume. All samples were partially demagnetized to isolate the characteristic remanent magnetization (ChRM) by removing spurious overprint magnetizations. Isothermal remanent magnetization (IRM) acquisition studies indicated that the magnetic grains within these sediments have low coercivities (Parson, Hawkins, Allan, et al., 1992), so alternating-field (AF) demagnetization was used. Approximately 
$50 \%$ of the samples were treated to detailed AF demagnetization routines, with $10-12$ steps up to $100-\mathrm{mT}$ field strength. The remainder of the samples were treated to an abbreviated AF demagnetization series, typically with 7 steps up to $60 \mathrm{mT}$.

The ChRM directions were found from an orthogonal vector plot of the AF demagnetization data for each sample. Straight-line sections toward the origin indicate univectorial decay of the magnetization vector and were assumed to represent the ChRM. Three or more (typically 4-5) directions from the straight line section were averaged using Fisher statistics (Fisher, 1953) to obtain the mean ChRM direction and the circular standard deviation (CSD) of the directions, the latter to be used as a measure of the repeatability and reliability of the ChRM direction.

Despite efforts to identify and discard unreliable sample data, in most analyses a few percent of the samples gave virtual geomagnetic poles (VGP) that did not fall near or within the main cluster of VGPs. Excising such data is a common problem for paleomagnetic studies, but there is no universally accepted analytical technique for doing so. We used $\Theta_{95}$, the radius of the circle around the Fisher mean, within which $95 \%$ of the sample population should lie (McFadden, 1980) as an outlier test. Samples outside this circle were considered outliers. According to McFadden (1980), the use of $\Theta_{95}$ as an outlier criterion is not strictly correct. Nevertheless, it provides an objective measure for rejecting poor data and typically those data discarded are those few that would have been chosen "by eye".

The analysis of APC and RCB core samples naturally fell into two different divisions. This was mainly a result of the different methods used in orienting the two types of samples, but also because the APC cores contain younger sediment than the RCB cores, so there was also an obvious division by age.

\section{APC Core Orientation}

The APC cores were oriented with the Eastman-Whipstock multishot orientation tool. This device is a miniature camera that photographs a compass and pendulum-bob inclinometer. Through a slot-key arrangement on its pressure case, the multishot tool is attached and aligned with the sinker bar-core barrel assembly that contains the core liner. The core liner is positioned so that the double line on the working half is aligned with the fiducial mark on the compass and a nonmagnetic drill collar is placed in the drill string bottom assembly at the level of the tool so that the magnetic field of the drill string does not significantly affect the compass reading when the core barrel is in place. Data from the multishot tool give the azimuth of the double line relative to magnetic north as well as the off-vertical tilt of the core and the tilt direction. Sample ChRM declinations were first corrected for the azimuth angle and the present magnetic declination at the site. The ChRM vectors were subsequently rotated about a horizontal axis perpendicular to the core tilt direction to correct for the off-vertical angle. The core tilts were small, ranging from $1^{\circ}$ to $2^{\circ}$ (Leg $135 \mathrm{APC}$ core orientation data are given in Parson, Hawkins, Allan, et al., 1992).

Nonhorizontal strata were cored in Hole 841A, so bedding corrections were made for samples from this hole. Two different types of bedding correction were tried. Both used the dips and dip directions of strata in the APC cores reoriented using the multishot orientation data (Appendix A). One method reoriented samples to the mean dip and dip direction calculated from all bed forms in that core. The other made the assumption that samples from a given sediment layer were laid down horizontally upon the stratal boundary at its base, so samples were corrected for the dip and dip direction of the nearest bed form below.

\section{APC Core Paleomagnetic Pole Calculations}

Because only one set of orientation data was taken per core, mean paleomagnetic directions were calculated using a two-tier approach. First, a mean direction was determined for each core using Fisher statistics (Fisher, 1953). At this first step, we used the $\Theta_{95}$ value to reject outlier data. Typically this method only rejected a few percent of the samples. For the second tier of calculations, that of determining a mean pole, we grouped all of the oriented APC cores from Holes $840 \mathrm{C}$ and $841 \mathrm{~A}$ because these cores are few in number and of about the same age.

Fisher statistics were not used to determine the mean pole location and its error limits because the underlying assumption of this method is that errors in direction are isotropic. Instead, the scatter in absolute declination values was larger than that of inclination because the error from core orientation is mainly in azimuth. Consequently, we used a least-squares method (Gordon and Cox, 1980) that can calculate a mean pole using declination and inclination values independently. This method finds the pole location that minimizes the distance between the average pole location and that predicted by each datum. It also can determine an elliptical $95 \%$ confidence region around that pole by linear propagation of errors from the estimated precision of inclination and declination (Gordon and Cox, 1980). Another favorable feature of this method is that the weight given to each datum is inversely proportional to its error; so that the more precisely determined data place more constraint on the pole location. Finally, from the misfits of the data to the model pole, the method can calculate a $\chi^{2}$ statistic that can be compared to $95 \%$ confidence limits in standard statistical tables. If the statistic falls outside the confidence limits, then the estimated data errors are inconsistent with the distribution of data (Gordon and Cox, 1980).

In calculating the pole location and its confidence ellipse, we wished to account for the systematic error inherent in the APC orientation process, but there exist no reliable estimates of this error. We assumed that orientation error only affected declination values. This is not strictly true, but should be a good approximation because the off-vertical tilt of these cores is small. To calculate the mean variance caused by orientation error, $S_{o}^{2}$, we assumed that the observed univariate variance in mean-core declinations, $S_{t d}{ }^{2}$, has two parts:

$$
S_{t d}^{2}=S_{o}^{2}+S_{b}^{2},
$$

where $S_{b}{ }^{2}$ is the between-core declination variance in the absence of orientation errors. We estimated $S_{b}^{2}$ by the variance of core-mean inclinations (assuming within core errors to be isotropic), calculated $S_{t d}{ }^{2}$ from the observed variance of core-mean declinations, and solved for $S_{o}{ }^{2}$. We wanted the estimated errors of each core mean direction to reflect the precision of the core mean, so we used $\alpha_{63}$, the two-dimensional angular standard deviation from Fisher (1953) statistics, to calculate univariate standard deviations in paleomagnetic inclination $\left(S_{i}\right)$ and declination $\left(S_{d}\right)$ for each core (Table 1$)$. To arrive at univariate equivalents, we used the relations derived by Demarest (1983):

$$
S_{i}=f \alpha_{63}
$$

and

$$
S_{d}=f \sin ^{-1}\left[\sin \left(\alpha_{63) / \sin }(\delta)\right],\right.
$$

where $d$ is the paleomagnetic colatitude and $f$ is a factor between 0.70 and 0.80 that depends on the number of independent samples (Demarest, 1983). Finally, the standard deviation of a core-mean declination was calculated by adding the within-core errors and the average orientation error:

$$
S_{d c}=\left(S_{d}^{2}+S_{o}^{2}\right)^{1 / 2}
$$

\section{RCB Core Sample Orientation}

Pieces from RCB cores are typically unoriented azimuthally because the core barrel tends to spin as it advances. In some holes, however, dipping sedimentary bed forms can be imaged in the bore- 
Table 1. APC core-mean paleopole data.

\begin{tabular}{|c|c|c|c|c|c|c|c|c|c|c|}
\hline \multirow[b]{2}{*}{$\begin{array}{l}\text { Core } \\
\text { number }\end{array}$} & \multicolumn{2}{|c|}{ Paleopole } & \multirow[b]{2}{*}{$N$} & \multirow[b]{2}{*}{$\alpha_{95}$} & \multirow[b]{2}{*}{$k$} & \multirow[b]{2}{*}{ Dec } & \multirow[b]{2}{*}{$S_{d c}$} & \multirow[b]{2}{*}{ Inc } & \multirow[b]{2}{*}{$S_{i}$} & \multirow[b]{2}{*}{$\begin{array}{l}\text { Bed } \\
\text { corr. }\end{array}$} \\
\hline & $\begin{array}{l}\text { Latitude } \\
\left({ }^{\circ} \mathrm{N}\right)\end{array}$ & $\begin{array}{c}\text { Longitude } \\
\left({ }^{\circ} \mathrm{E}\right)\end{array}$ & & & & & & & & \\
\hline \multicolumn{11}{|c|}{$135-840 \mathrm{C}-$} \\
\hline $2 \mathrm{H}$ & -39.1 & 106.0 & 3 & 20.4 & 37.5 & 55.4 & 21.9 & -39.8 & 8.9 & $\mathrm{~N}$ \\
\hline $3 \mathrm{H}$ & -57.9 & 128.8 & 11 & 10.1 & 21.5 & 33.2 & 20.4 & -56.2 & 4.6 & $\mathrm{~N}$ \\
\hline $4 \mathrm{H}$ & -63.7 & 102.7 . & 11 & 8.2 & 31.7 & 28.6 & 19.2 & -41.0 & 3.7 & $\mathrm{~N}$ \\
\hline $5 \mathrm{H}-1$ & -10.7 & $121.0^{\circ}$ & 6 & 4.8 & 199.8 & 89.7 & 18.9 & -47.5 & 2.2 & $\mathrm{~N}$ \\
\hline $5 \mathrm{H}-2$ & -83.9 & 168.4 & 3 & 15.6 & 63.5 & 1.9 & 21.1 & -46.9 & 6.7 & $\mathrm{~N}$ \\
\hline $6 \mathrm{H}$ & -61.6 & $254.4^{\circ}$ & 8 & 6.5 & 73.2 & 329.2 & 19.1 & -47.7 & 3.0 & $\mathrm{~N}$ \\
\hline $7 \mathrm{H}$ & -53.6 & 119.0 & 12 & 8.3 & 28.2 & 39.6 & 19.6 & -51.7 & 3.8 & $\mathrm{~N}$ \\
\hline $10 \mathrm{H}$ & -85.3 & 294.0 & 3 & 13.4 & 83.7 & 355.3 & 20.0 & -36.8 & 5.9 & $\mathrm{~N}$ \\
\hline \multicolumn{11}{|c|}{$135-841 \mathrm{~A}-$} \\
\hline $4 \mathrm{H}$ & & 95.6 & 19 & 6.1 & 30.9 & 9.6 & 18.9 & -40.7 & 2.7 & $\mathrm{~N}$ \\
\hline $5 \mathrm{H}$ & -50.7 & 103.8 & 14 & 5.3 & 58.3 & 43.0 & 18.9 & -41.1 & 2.4 & $\mathrm{~N}$ \\
\hline $6 \mathrm{H}$ & -62.6 & 129.8 & 7 & 28.3 & 5.5 & 28.0 & 29.7 & -56.0 & 12.7 & $\mathrm{~N}$ \\
\hline $8 \mathrm{H}$ & -73.2 & 118.2 & 9 & 24.1 & 5.5 & 17.7 & 24.8 & -48.0 & 10.8 & $\mathrm{~N}$ \\
\hline \multicolumn{11}{|c|}{ 135-841A-(with dip corrections) } \\
\hline $4 \mathrm{H}$ & -79.6 & 149.2 & 19 & 6.9 & 24.3 & 7.1 & 19.3 & -51.0 & 3.2 & A \\
\hline $5 \mathrm{H}$ & -60.9 & 98.5 & 14 & 4.7 & 72.2 & 31.6 & 18.8 & -39.1 & 2.1 & $\mathrm{~A}$ \\
\hline $6 \mathrm{H}$ & -80.0 & 168.3 & 7 & 26.1 & 6.3 & 2.4 & 26.9 & -52.4 & 11.8 & 1 \\
\hline $8 \mathrm{H}$ & -70.1 & 111.2 & 9 & 22.0 & 6.4 & 21.6 & 23.4 & -46.2 & 10.0 & i \\
\hline
\end{tabular}

Notes: Paleopole $=$ mean paleomagnetic pole calculated with Fisher statistics; $N=$ number of samples used for calculation; $\alpha_{95}=$ radius of $95 \%$ confidence circle around mean pole; $k=$ precision parameter; "Dec" and "Inc" = mean declination and inclination (calculated from pole); $S_{d c} S_{i}=$ univariate standard deviation of declination and inclination (see text); Bed corr. (bedding correction) abbreviations as follows: $\mathrm{N}=$ none, $\mathrm{A}=$ average bedding dip and dip direction in core, and $\mathrm{I}=$ individual layer dip and dip direction. Values labeled with an asterisk $\left({ }^{*}\right)$ indicate pole not used to calculate mean direction.

hole wall by the FMS wireline log, and these bed forms can be recognized in the recovered core. Because the FMS contains a threeaxis magnetometer, features in its images can be oriented relative to the magnetic field within a borehole walled with weakly magnetic rock (e.g., most sediments). If the same features can be recognized within the core, they can be reoriented into geographic coordinates.

The methodology of reorienting samples with reference to FMS logs is discussed elsewhere (MacLeod et al., 1992; MacLeod, this volume); here we only briefly outline the steps involved. Features amenable to orientation should be tilted and planar, so that a welldefined dip angle and dip direction can be determined from the FMS $\log$ and core. For Leg 135, the most suitable features were tilted bed forms and faults, found principally in Hole 841B.

We examined the Hole 841B FMS logs for faults and bed forms. Tilted planar features appear as sinusoids on FMS borehole images, so we used a computer workstation with proprietary Schlumberger software that determines the best-fitting sinusoid to an FMS log feature and then calculates the implied dip and dip direction.

Dips of tilted planar features within the cores were measured on two perpendicular axes, usually along the split face of the working half and on a cut made perpendicular to the split face. These directions are along the $y$ and $x$ axes, respectively, of ODP-standard core coordinates (with the $z$-axis positive downward). With the two measured angles, $\alpha$ and $\beta$, we used the cross product of the two perpendicular dip vectors to calculate the dip and dip direction of the plane in core coordinates:

$$
\begin{aligned}
& \operatorname{dip}=\cos ^{-1}[\cos (\alpha) \cos (\beta)], \\
& \operatorname{dir}=\tan ^{-1}[\tan (\beta) / \tan (\alpha)] .
\end{aligned}
$$

Here, $\alpha$ is the dip angle along the $x$ axis (toward the double line on the working half), positive downcore, and $\beta$ is the dip angle along the positive $y$ axis, positive downcore and to the right side of the core (see MacLeod, this volume).

The challenge was to then match features seen in the cores on a $1: 1$ basis with the same features in the FMS logs (or vice versa). There is uncertainty in the relation of FMS log depths and core depths owing to the arbitrary placement of pieces within a core when recovery is incomplete and because of inaccuracies in determining the physical location of the drilled interval relative to the wireline logging tool. As a consequence, given a feature in the core we had to search for a corresponding feature in the FMS $\log$ within a "window" of probable location. In many locations it was possible to make a convincing match. Of 120 samples we oriented, $93(78 \%)$ were matched with FMS log features; 31 of these were faults, 51 were bed forms. In addition, 4 samples were oriented by inference from adjacent oriented samples (e.g., a sample between two bed forms matched to the FMS $\log$ with similar dip directions is given the same dip direction).

All of the remaining 33 oriented core features were bed forms from sections of the borehole in which the bedding dip and dip direction were relatively constant (Fig. 2). For these samples, we used an average of the dip directions derived from values determined with the Schlumberger workstation. The mean dip directions were variable in direction and consistency, with $95 \%$ confidence cones of the mean directions in Hole $841 \mathrm{~B}$ ranging from $3.5^{\circ}$ to $35.6^{\circ}$ (Appendix A).

\section{RCB Core Sample Statistics}

Unlike the samples from the APC cores, each of those oriented using the FMS log is independently oriented, so we did not calculate core-mean directions for the RCB samples. Instead, all of the inclinations and declinations for samples of a given group were used to determine a mean paleomagnetic pole using the Gordon and Cox (1980) least-squares method. The same standard error values for declination and inclination were used for each sample, and these were determined by calculating the univariate standard deviations of these parameters for the group after discarding outlier directions. Outliers were identified by the $\Theta_{95}$ test, as for the APC core samples. Once again, this method rejected only a small number of directions, typically $<5 \%$. The $\chi^{2}$ statistic values for all poles fell within $95 \%$ confidence limits (Table 2), implying that the estimated errors are reasonable.

We tried analyzing the directions of the RCB core samples in several different groups. There was a natural division by age into late Miocene (Cores 135-841B-2R to -31R) and early Miocene (Cores 135-841B-32R to -41R) with a few older samples (from Cores 135$841 \mathrm{~B}-42 \mathrm{R}$ to $-44 \mathrm{R})$. We also compared the directions of normal and reversed samples for a "reversal test". Furthermore, to make sure that 


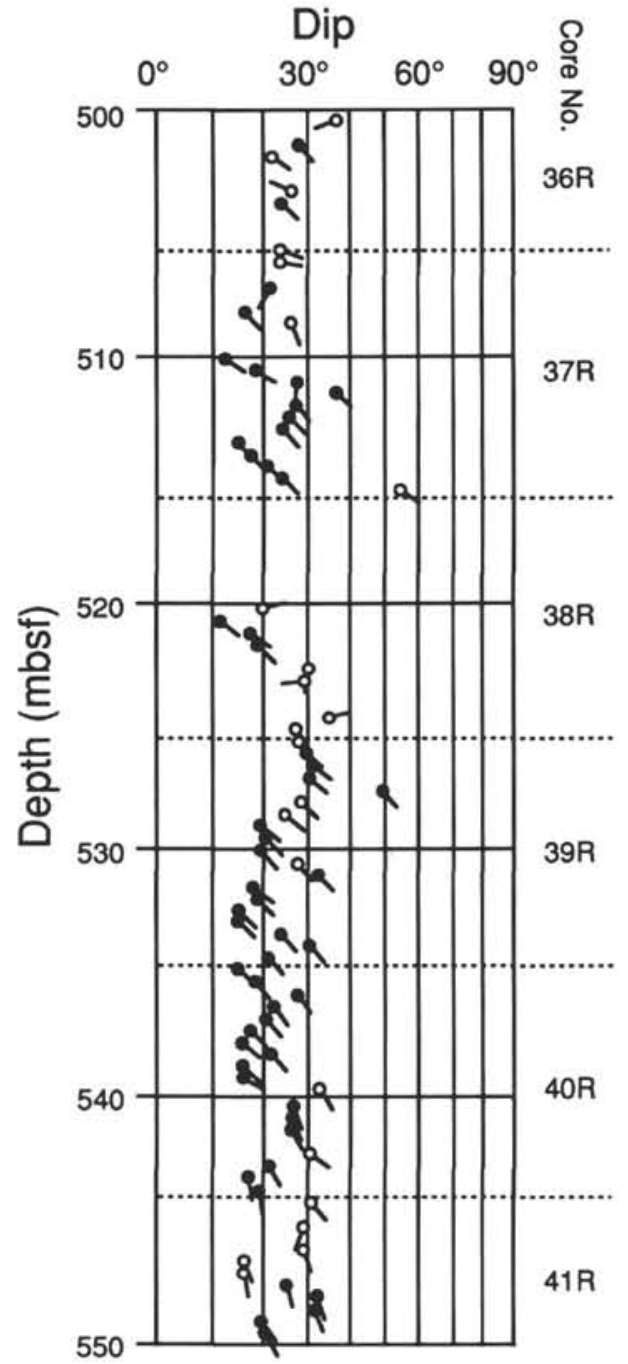

Figure 2. Example of dip angle and dip-direction values from FMS dipmeter $\log$, Hole 841B. Graph plots dip magnitude on horizontal axis vs. depth on vertical axis. "Tails" on data points show dip direction: north $\left(0^{\circ}\right)$ is up and south $\left(180^{\circ}\right)$ is down. Solid symbols show more reliable dip values than open symbols. This section of Hole $841 \mathrm{~B}$ has relatively constant bed dips and dip directions. Data are from the automatic-dipmeter log, which is derived from FMS microresistivity images and averages over about $0.5 \mathrm{~m}$ in depth.

no bias was being introduced by the method of orientation and bed-dip corrections, we compared sample virtual geomagnetic pole (VGP) clusters with the samples reoriented in four different ways. First, the samples were rotated in azimuth only, with no correction for bed dip. The second correction method was to correct the sample azimuths and then make individual corrections for bed dip using the dip of the strata within the sample. The third method was to use the average stratal dip and dip direction, determined from the FMS log, for the reorientation and bed-dip correction (Appendix A). For the final correction method, the samples were reoriented to the average FMS bed-dip direction, but the individual sample stratal dips were used for making the beddip correction.

\section{RESULTS}

\section{APC Core Magnetic Properties}

A total of 127 samples from oriented APC cores were measured; 111 samples from 11 cores gave good results: 58 samples from Hole $840 \mathrm{C}$ and 53 samples from Hole 841A (Appendix B). The number of samples per core ranged from 3 to 19 , the lower numbers a result of low recovery. All of the APC core samples were of nannofossil ooze with varying amounts of volcanic ash (Parson, Hawkins, Allan, et al., 1992). Because of the volcaniclastic component, sample natural remanent magnetizations (NRMs) were high, ranging from 15.45 to 894.71 $\mathrm{mAm}^{-1}$ (Appendix B). These samples typically displayed pervasive upward-directed overprints thought to have resulted from exposure to magnetic fields within or around the drill string. This overprint was usually removed easily by AF demagnetization of 15 - to $20-\mathrm{mT}$ field strength (Fig. 3). Most samples had mean destructive fields (MDFs) of only about 2 to $4 \mathrm{mT}$, indicating a low coercivity component in the magnetization and explaining the propensity of the samples to acquire an overprint, but some samples had somewhat higher MDFs, in the range of 10 to $15 \mathrm{mT}$. Most samples also displayed stable behavior during $\mathrm{AF}$ demagnetization (Fig. 3) and yielded ChRMs with CSD values of a few degrees or less (Appendix B).

Only about $15 \%$ of the samples displayed unreliable behavior. These unreliable samples were not uniformly distributed; often they were found preferentially in the deeper APC cores. In Hole 840C, Cores $135-840 \mathrm{C}-9 \mathrm{H},-10 \mathrm{H}$, and $-12 \mathrm{H}$ were particularly affected. In Hole $841 \mathrm{~A}$, Cores $135-841 \mathrm{~A}-4 \mathrm{H}$ and $-5 \mathrm{H}$ yielded excellent results, whereas Cores $135-841 \mathrm{~A}-6 \mathrm{H}$ and $-8 \mathrm{H}$ gave poor results. This trend may be a result of some process, such as anoxic dissolution (e.g., Karlin and Levi, 1985), that destroyed the magnetization with progressive burial.

In initial shipboard studies, a trend of declination values rotating downcore by $2.7^{\circ}$ to $5.5^{\circ}$ per meter was noted in whole-core measurements made of Hole 841A APC cores (Parson, Hawkins, Allan, et al., 1992). Similar trends have been noted by other paleomagnetists working on ODP APC cores and had been attributed by some to rotation of the core within the liner. Discrete samples from the Hole $841 \mathrm{~A}$ cores did not show the same trends in properly isolated ChRM directions (Fig. 4). Because shipboard whole-core paleomagnetic measurements were restricted to AF demagnetization levels of $15 \mathrm{mT}$ or less, this result suggests that the apparent rotation was caused by an incompletely removed overprint magnetization.

Because of the large orientation errors, it was impossible to perform a reversal test by comparing normal and reversed polarity sample directions between cores. This necessitated comparing the directions from samples within a single core. Only one core, 135 $841 \mathrm{~A}-4 \mathrm{H}$, had a sufficient number of normal and reversed samples for a reliable comparison. The normal and reversed samples from this core gave mean directions with overlapping $95 \%$ confidence circles that show the two means are not significantly different (Fig. 5). Thus, the Core $135-841 \mathrm{~A}-4 \mathrm{H}$ data pass a reversal test, implying that the $\mathrm{ChRM}$ directions are reliable and free of overprint. Because the samples from the other APC cores are similar in lithology and magnetic behavior, it is likely that their directions are also reliable.

\section{APC Paleomagnetic Poles}

Precision parameters $(k)$ and $\alpha_{95}$ values for core-mean paleomagnetic poles from the APC cores ranged from 5.5 to 199.8 and $4.8^{\circ}$ to $28.3^{\circ}$, respectively, indicating a large variability in the precision for each pole (Table 1). Most of the poles are relatively well determined, with $\alpha_{95}$ values of $20^{\circ}$ or less. However, three poles were determined with only three samples each (Cores $135-840 \mathrm{C}-2 \mathrm{H}$ and $-10 \mathrm{H}$, Section $135-840 \mathrm{C}-5 \mathrm{H}-2$ ), owing to low recovery, so they had relatively large $\alpha_{95}$ values. In addition, Cores $135-841 \mathrm{~A}-6 \mathrm{H}$ and $-8 \mathrm{H}$ gave poles with large $\alpha_{95}$ values because of high sample direction scatter, resulting from less-stable magnetizations.

APC cores from Hole $841 \mathrm{~A}$ contained dipping beds with average dips of $6.7^{\circ}$ to $26.0^{\circ}$ (Appendix A). Three different orientation methods were tried on these samples (no dip correction, average dip correction, individual layer correction; see Appendixes B and C), and the best results, defined by the least scatter indicated by the largest Fisher precision parameter, $k$, were found with different methods on 
Table 2. Mean paleomagnetic poles.

\begin{tabular}{|c|c|c|c|c|c|c|c|c|c|c|c|c|c|c|c|c|}
\hline \multirow[b]{2}{*}{ Pole } & \multicolumn{2}{|c|}{ Location } & \multirow[b]{2}{*}{$N$} & \multicolumn{3}{|c|}{$95 \%$ confidence ellipse } & \multirow[b]{2}{*}{$\begin{array}{l}\sigma_{D} \\
\left({ }^{\circ}\right)\end{array}$} & \multirow[b]{2}{*}{$\begin{array}{l}\sigma_{l} \\
\left({ }^{\circ}\right)\end{array}$} & \multirow[b]{2}{*}{$\begin{array}{l}\delta_{c} \\
\left({ }^{\circ}\right)\end{array}$} & \multirow[b]{2}{*}{$\begin{array}{l}\Delta \delta \\
\left({ }^{\circ}\right)\end{array}$} & \multirow[b]{2}{*}{$\begin{array}{l}D \\
\left({ }^{\circ}\right)\end{array}$} & \multirow[b]{2}{*}{$\begin{array}{l}\Delta D \\
\left({ }^{\circ}\right)\end{array}$} & \multirow[b]{2}{*}{$\begin{array}{l}R \\
\left({ }^{\circ}\right)\end{array}$} & \multirow[b]{2}{*}{$\begin{array}{l}\Delta R \\
\left({ }^{\circ}\right)\end{array}$} & \multirow[b]{2}{*}{$\chi^{2}$} & \multirow[b]{2}{*}{$\begin{array}{l}\text { Age } \\
\text { (Ma) }\end{array}$} \\
\hline & $\begin{array}{l}\text { Latitude } \\
\left({ }^{\circ} \mathrm{N}\right)\end{array}$ & $\begin{array}{c}\text { Longitude } \\
\left({ }^{\circ} \mathrm{E}\right)\end{array}$ & & $\begin{array}{c}\text { Major } \\
\left({ }^{\circ}\right)\end{array}$ & $\begin{array}{c}\text { Minor } \\
\left({ }^{\circ}\right)\end{array}$ & $\begin{array}{l}\text { Azimuth } \\
\left({ }^{\circ}\right)\end{array}$ & & & & & & & & & & \\
\hline A & -69.0 & 112.2 & 10 & 14.2 & 2.9 & 352 & Var & Var & 62.1 & 2.3 & 23.0 & 12.5 & 20.4 & 12.6 & 1.5 & 4.0 \\
\hline B & -53.7 & 104.0 & 111 & 6.8 & 1.8 & 7 & 31.9 & 10.5 & 65.5 & 1.4 & 39.8 & 6.0 & & & 1.2 & \\
\hline C & -63.0 & 100.7 & 111 & 7.3 & 1.9 & 6 & 34.2 & 10.9 & 66.2 & 1.5 & 29.5 & 6.4 & & & 1.2 & \\
\hline D & -62.9 & 100.6 & 111 & 7.6 & 1.8 & 6 & 35.6 & 10.5 & 66.2 & 1.4 & 29.6 & 6.6 & & & 1.3 & \\
\hline $\mathrm{E}$ & -69.6 & 99.1 & 106 & 10.0 & 1.9 & 4 & 45.7 & 11.0 & 66.2 & 1.5 & 21.9 & 8.7 & & & 1.2 & \\
\hline $\mathrm{F}$ & -70.2 & 90.4 & 24 & 9.5 & 3.0 & 12 & 21.1 & 8.8 & 69.2 & 2.4 & 21.1 & 8.1 & 15.5 & 8.3 & 1.5 & 8.6 \\
\hline G & -37.0 & 106.4 & 19 & 11.7 & 3.0 & 13 & 22.6 & 7.4 & 66.8 & 2.4 & 58.0 & 10.2 & 52.4 & 10.4 & 1.4 & 8.6 \\
\hline $\mathrm{H}$ & -28.5 & 110.5 & 26 & 11.4 & 2.9 & 15 & 26.1 & 8.1 & 65.5 & 2.3 & 67.9 & 10.0 & 62.3 & 10.2 & 1.3 & 8.6 \\
\hline I & -77.8 & 95.2 & 22 & 7.2 & 3.8 & 5 & 15.7 & 100 & 66.7 & 3.0 & 13.3 & 6.3 & 7.7 & 6.6 & 1.3 & 8.6 \\
\hline J & -38.7 & 109.3 & 19 & 12.8 & 5.1 & 10 & 25.2 & 11.7 & 64.1 & 4.1 & 56.7 & 11.4 & 51.1 & 11.5 & 1.2 & 8.6 \\
\hline $\mathrm{K}$ & -28.8 & 113.0 & 27 & 12.6 & 4.6 & 13 & 29.8 & 12.2 & 63.2 & 3.6 & 68.2 & 11.3 & 62.6 & 11.4 & 1.2 & 8.6 \\
\hline $\mathrm{L}$ & -57.7 & 104.0 & 54 & 7.5 & 1.9 & 5 & 24.5 & 7.6 & 65.0 & 1.5 & 35.4 & 6.5 & 26.2 & 6.7 & 1.4 & 15.3 \\
\hline M & -76.2 & 93.0 & 57 & 6.3 & 2.0 & 8 & 20.9 & 8.8 & 67.3 & 1.6 & 14.9 & 5.4 & 5.7 & 5.7 & 1.4 & 15.3 \\
\hline
\end{tabular}

Notes: Letters representing poles are as follows: $\mathrm{A}=$ Holes $840 \mathrm{C}$ and $841 \mathrm{~A}$ APC mean pole; $\mathrm{B}=\mathrm{Hole} 841 \mathrm{~B}$, all data, no bed-dip corrections; $\mathrm{C}=$ Hole $841 \mathrm{~B}$, all data, individual bed-dip corrections; $\mathrm{D}=$ Hole $841 \mathrm{~B}$, all data, FMS average bed-dip corrections; $\mathrm{E}=\mathrm{Hole} 841 \mathrm{~B}$, all data, FMS average dip direction alignment; $\mathrm{F}=$ Hole $841 \mathrm{~B}$, late Miocene normal data, no bed-dip corrections; $\mathrm{G}=\mathrm{Hole} 841 \mathrm{~B}$, late Miocene reversed data, no bed-dip corrections; $\mathrm{H}=$ Hole $841 \mathrm{~B}$, late Miocene normal outlier + reversed data, no bed-dip corrections; $\mathrm{I}=\mathrm{Hole} 841 \mathrm{~B}$, late Miocene normal data, individual bed-dip corrections; $\mathrm{J}=$ Hole $841 \mathrm{~B}$, late Miocene reversed data, individual bed-dip corrections; $\mathrm{K}=\mathrm{Hole} 841 \mathrm{~B}$, late Miocene normal outlier + reversed data, individual bed-dip corrections; $\mathrm{L}=$ Hole $841 \mathrm{~B}$, early Miocene data, no bed-dip corrections; $\mathrm{M}=\mathrm{Hole} 841 \mathrm{~B}$, early Miocene data, individual bed-dip corrections. $N=$ number of independent samples. "Major", "Minor", and "Azimuth" = major and minor semi-axis lengths, and azimuth of major axis clockwise from north; $\sigma_{D}, \sigma_{t}=$ univariate standard deviations of declination and inclination; $\delta_{c}, \Delta \delta=$ corrected paleocolatitude (Cox and Gordon, 1984) and 95\% confidence limit; $D, \Delta D=$ mean declination and $95 \%$ confidence limit; $R, \Delta R=$ declination anomaly and $95 \%$ confidence limit; $\chi^{2}=$ reduced chi-square statistic with $2 N-2$ degrees of freedom.

$135-840 \mathrm{C}-2 \mathrm{H}-\mathrm{CC}, 18-20 \mathrm{~cm}$ $(0-60 \mathrm{mT})$

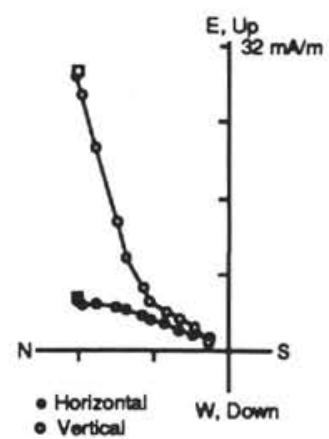

$135-840 \mathrm{C}-7 \mathrm{H}-2,22-24 \mathrm{~cm}$ $(0.00 \mathrm{mT})$

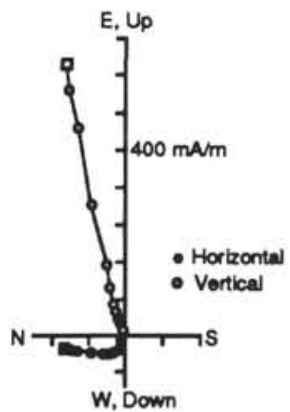

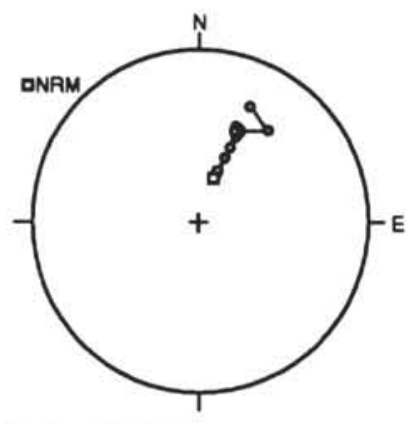
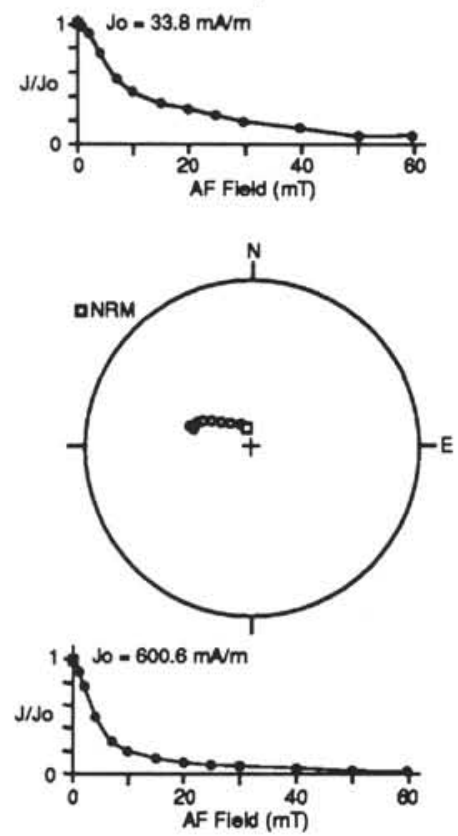

$135-841 \mathrm{~A}-5 \mathrm{H}-3,40-42 \mathrm{~cm}$ $(0-60 \mathrm{mT})$

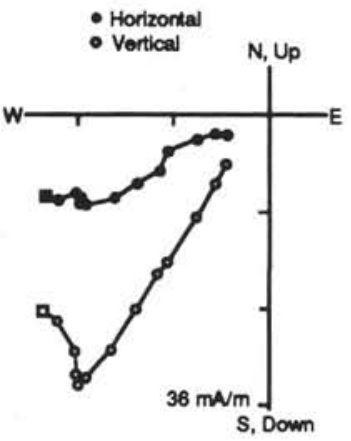

s, Down

$135-841 \mathrm{~A}-8 \mathrm{H}-3,70-72 \mathrm{~cm}$ $(0-60 \mathrm{mT})$

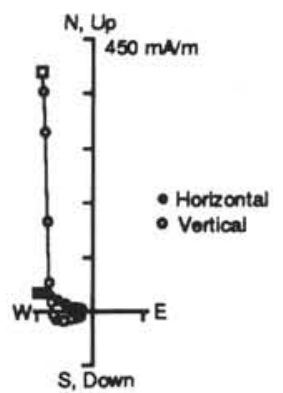

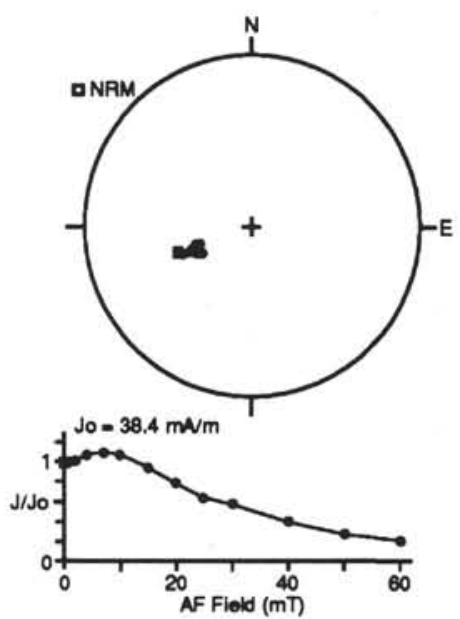

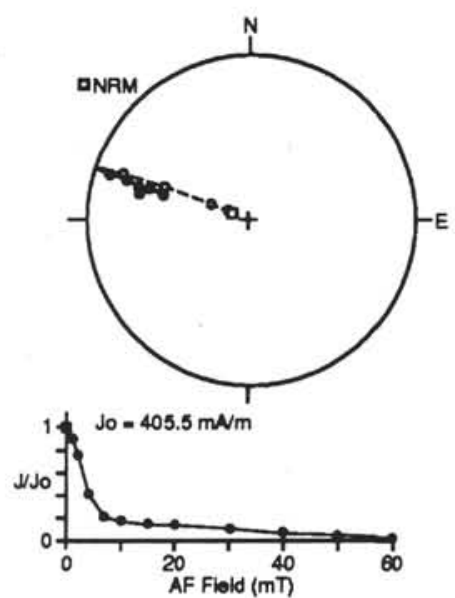

Figure 3. Stepwise alternating-field (AF) demagnetization behavior of four representative samples from oriented APC cores Holes $840 \mathrm{C}$ and $841 \mathrm{~A}$. Three plots are shown for each sample: (left) orthogonal vector end-point plot; (upper right) vector end-points on equal-area plot (open symbols denote point on upper hemisphere; solid symbols, lower hemisphere); (lower right) normalized magnetization intensity vs. demagnetization field strength. Magnetic directions are shown in sample coordinates. 

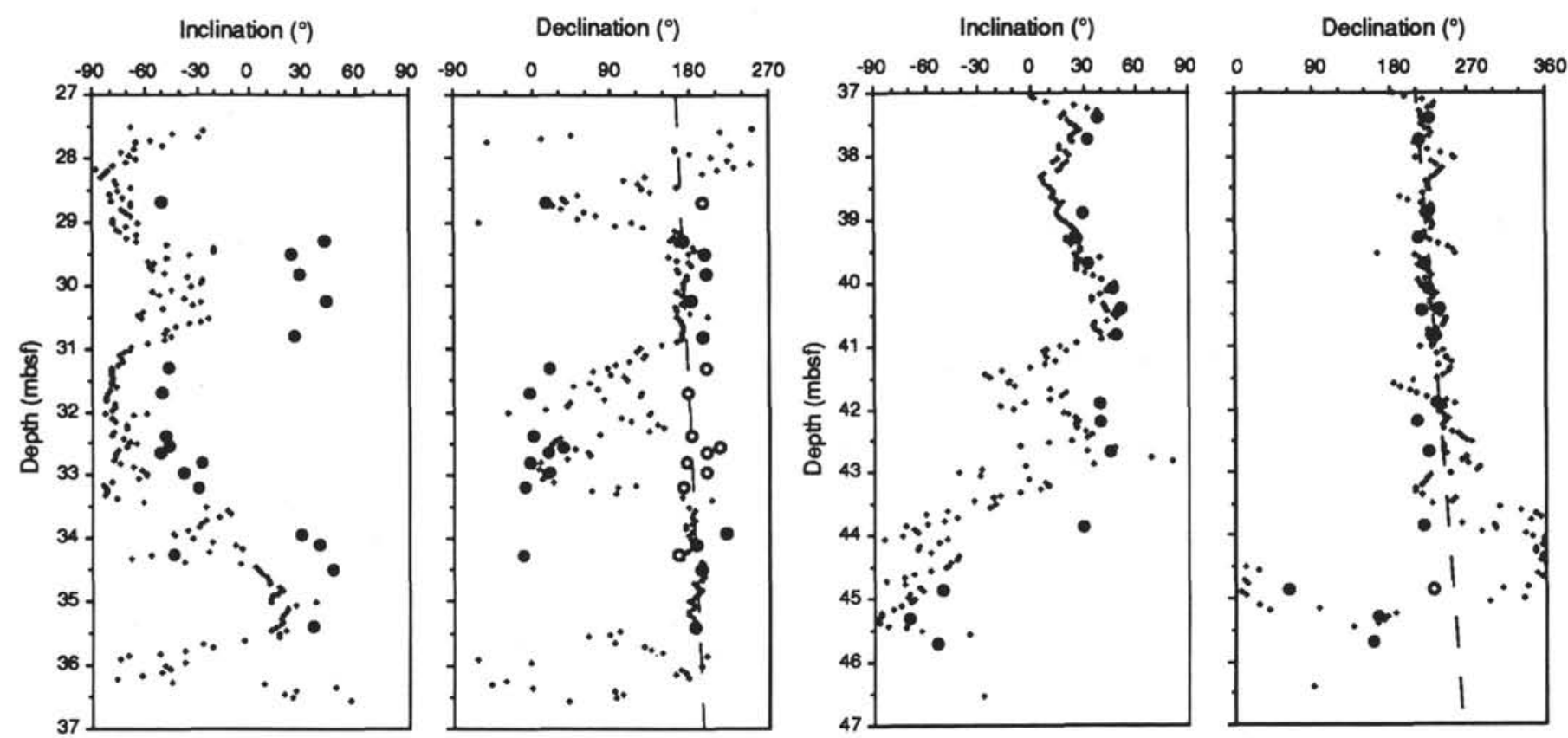

Figure 4. Inclination and declination trends in Cores $135-841 \mathrm{~A}-4 \mathrm{H}$ and $-5 \mathrm{H}$. Shipboard whole-core (small symbols) and land-laboratory discrete sample (large symbols) inclination and declination data are plotted vs. depth (mbsf). Whole-core data are measurements after 15-mT AF demagnetization; discrete sample data were AF demagnetized to isolate characteristic remanence direction. In declination plots, discrete sample normal-polarity declinations have been inverted (open symbols) to accentuate trends. Dashed lines are declination trends determined from whole-core measurements (see Parson, Hawkins, Allan, et al., 1992). Whole-core trends are not evident in the more thoroughly demagnetized discrete sample data.

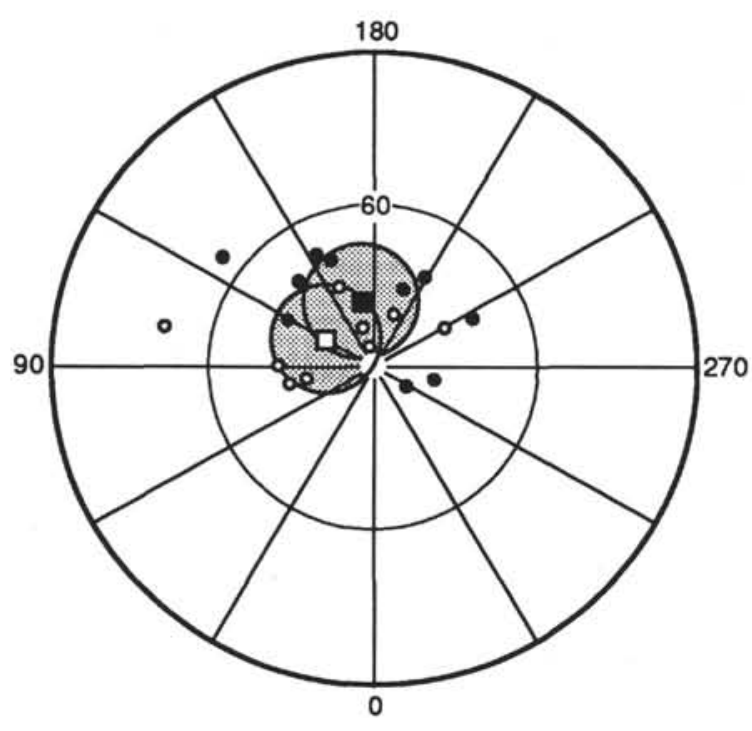

Figure 5. Reversal test, Core 135-841A-4H. Normal and inverted reversedpolarity VGPs are compared. Open circles $=$ reversed-polarity VGPs. Solid circles $=$ normal-polarity VGPs. Open and solid squares $=$ mean VGPs for reversed and normal-polarity samples. Large circles with stipple $=\alpha_{95}$ circles for mean pole positions. Map is an equal-area plot of the Southern Hemisphere.

different cores. Because the differences in the amount of scatter among methods were usually small and probably not significant, we simply used the core-mean magnetic directions from the dip correction method that gave the best results for each core (Table 1).

The core-mean paleomagnetic poles (Table 1) display considerable scatter, most of it trending along the $110^{\circ}$ meridian (Fig. 6). This is simply the effect of the large variance in declinations caused by the large core-azimuth orientation error $\left(S_{o}=18.6^{\circ}\right)$. This orientation error is probably larger than it might ordinarily be owing to a problem peculiar to the Hole 840 C APC cores. Those cores typically contained plugs of nannofossil ooze, with lengths of a few tens of centimeters to a few meters, separated by coarse, unconsolidated volcanic ash (Parson, Hawkins, Allan, et al., 1992). During handling on deck, it was not uncommon to see water and ash sloshing about in some of these cores. As a result, it was possible for the small plugs of ooze to break free from the liner and rotate. A good example is the distinctly different average declinations $\left(1.9^{\circ}\right.$ and $89.7^{\circ}$ ) given by two different sections of Core $135-840 \mathrm{C}-5 \mathrm{H}$ (Table 1).

Because of the considerable scatter in paleomagnetic declinations caused by orientation errors, we used the outlier test to reduce the scatter of averaged VGPs. Those from Core 135-840C-6H and Section $135-840 \mathrm{C}-5 \mathrm{H}-1$ were found to be outside the $\Theta_{95}$ circle and were discarded from subsequent calculations. The mean paleopole calculated from the 10 remaining core-means is located at $-69.0^{\circ} \mathrm{N}, 112.2^{\circ} \mathrm{E}$. It has a $95 \%$ confidence ellipse with a minor semi-axis length of $2.9^{\circ}$ and a major semi-axis of $14.2^{\circ}$ oriented along $352^{\circ}$. The reduced $\chi^{2}$ statistic has a value of 1.5 with 18 degrees of freedom, a value within $95 \%$ confidence limits ( 0.52 and 1.60 ), indicating the estimated error values propagated to determine the error ellipse are consistent with the observed data scatter.

\section{Hole 841B Sample Magnetic Properties}

Sediments recovered from Hole $841 \mathrm{~B}$ range from clay to sandstone and are mainly volcaniclastic in nature. Most of the paleomagnetic samples taken for this study are from the finer grained clay and clayey siltstone sections because fine-grained sediments often give better paleomagnetic results than coarser grained sediments. Like the APC core sediments described above, those from Hole 841B are strongly magnetic because of volcanogenic components. NRM values 


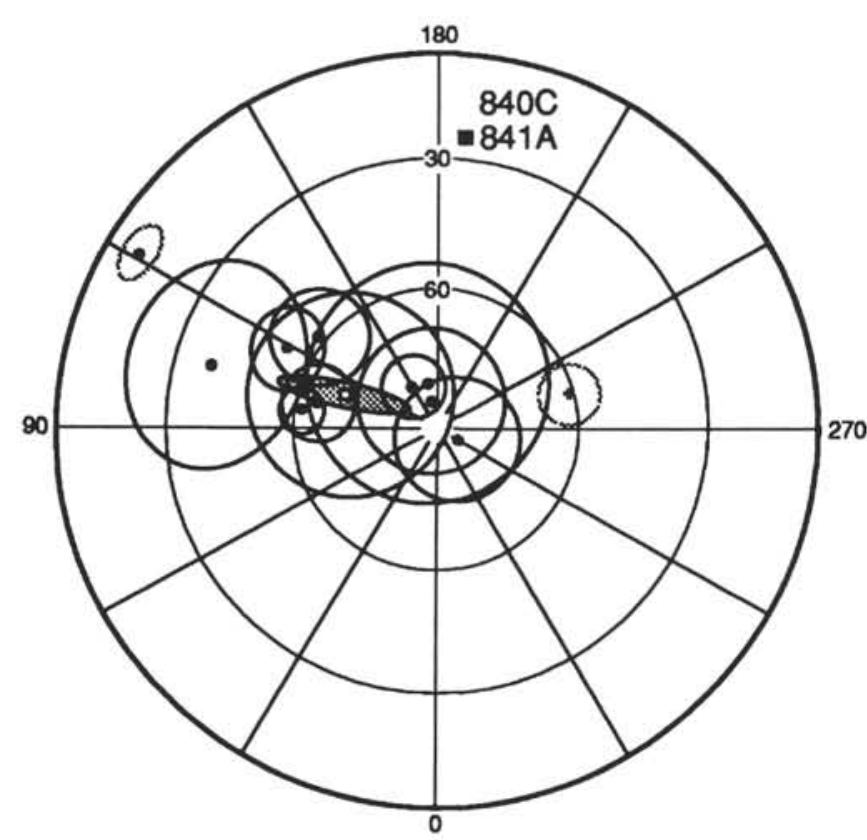

Figure 6. Paleomagnetic poles from Hole $840 \mathrm{C}$ and Hole 841A APC cores. Each pole location is shown by a small, filled circle and is surrounded by its $\alpha_{95}$ circle. Mean APC pole is shown by an open square and is surrounded by stippled $95 \%$ confidence ellipse. Grayed poles and $\alpha_{95}$ circles were considered outliers and rejected from mean-pole calculation (see text). Solid square $=$ location of drill sites. Map is an equal-area plot of the Southern Hemisphere.

for the oriented samples from Hole 841B range from 4.10 to 1205.78 $\mathrm{mAm}^{-1}$, but values of 50 to $200 \mathrm{mAm}^{-1}$ are typical (Appendix D).

IRM acquisition curves for Hole 841B samples generally display saturation in low applied fields (Fig. 7), implying that titanomagnetite is the most probable type of magnetic grain in the sediments. Like the APC core samples, those from Hole 841B were overprinted with an upward-directed magnetization, probably resulting from the drill string. It was usually possible to remove this overprint with $\mathrm{AF}$ demagnetization at field strengths of $20-40 \mathrm{mT}$ (Fig. 8). The behavior of most samples during $\mathrm{AF}$ demagnetization appeared to be reliable, with the removal of an overprint leaving segments of univectorial decay on orthogonal vector plots (Fig. 8). Accordingly, CSD values for the oriented Hole $841 \mathrm{~B}$ samples are mostly $<5^{\circ}$, indeed $64 \%$ are $<2^{\circ}$ (Appendix D), indicating well-determined magnetization vectors. A small percentage $(<5 \%)$ of samples behaved erratically during AF demagnetization or gave no stable ChRM direction; those with CSD values in excess of $12^{\circ}$ were not included in subsequent analyses. Notably, the best behaved samples, with low CSD values, are often in adjacent cores or core sections (Appendix D), implying that broadscale changes in sediment composition affect the magnetic stability.

\section{Hole 841B Paleomagnetic Poles}

Despite uncertainties in correlating the FMS logs and cores, the orientation of the samples worked well. Most sample VGPs are in the Southern Hemisphere in a streak from the South Pole to the equator along about $110^{\circ} \mathrm{E}$ (Fig. 9). Only about $10 \%$ of the VGPs appear to be outliers. Half of these, six samples in all, appeared to have been inverted, that is, they were the only "reversed polarity" samples in otherwise totally normally polarized sections (see Appendix D). The inversions of these samples were corrected so that their VGPs could be used in subsequent analyses.

As described above, we tried four methods for making azimuth and bed-dip corrections to examine the effects of the reorientation procedures. The four methods were (1) azimuth reorientation without

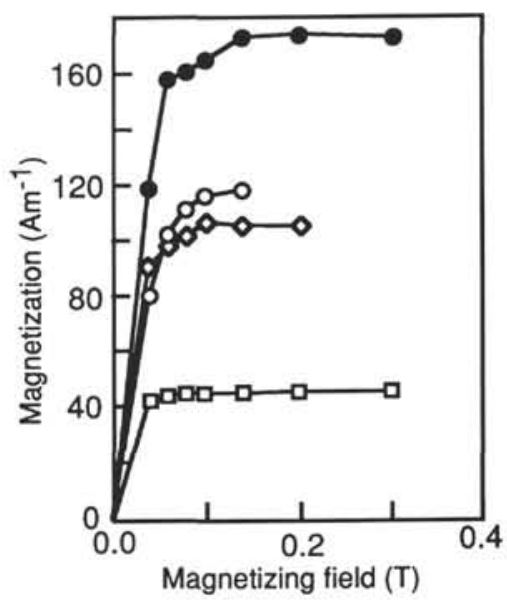

Figure 7. Acquisition of isothermal remanent magnetization (IRM) by Hole 841 B samples.

bed-dip corrections, (2) individual reorientation and bed-dip corrections, (3) correction to the average FMS dip and dip direction, and (4) reorientation to the average FMS dip direction but with individual bed-dip corrections (see Appendix E). The mean pole positions calculated from the four different treatments are little different (Fig. 9 and Table 2 ), the maximum distance between them being only $16.4^{\circ}$. The VGP scatter is greatest for Method 4 and least for Method 1, for which no bed-dip corrections were made. This is not only evident in the standard deviations of the declination and inclination values (Table 2) but is also clear visually (Figs. 9A and 9D). The fact that the sample VGPs cluster most tightly without bedding corrections could indicate that the samples acquired their magnetizations after they were tilted and that if a fold test were possible for these strata, they would fail to pass it; however, the difference in scatter is not statistically significant, so such an interpretation might not be correct.

When early Miocene VGPs were analyzed separately, we found that they did not seem to show as much declination scatter as the entire set of VGPs (Fig. 10). In this analysis, the least scatter occurred for the bed-dip corrected VGPs, which suggests that the scatter statistics are dependent on the subdivision of the data, so conclusions from scatter observations must be drawn carefully. Furthermore, a significant difference was evident in the mean pole positions calculated with and without bed-dip corrections: uncorrected and corrected VGPs gave poles at $-57.7^{\circ} \mathrm{N}, 104.0^{\circ} \mathrm{E}$ and $-76.2^{\circ} \mathrm{N}, 93.0^{\circ} \mathrm{E}$, respectively. The bed-dip corrected pole is much closer to both the geographic pole and the appropriate point on the reference polar wander path (Tables $2-3)$. It implies a declination of $14.9^{\circ} \pm 5.4^{\circ}$ (95\% confidence limit), which yields a declination anomaly (observed declination minus reference declination) of only $5.7^{\circ} \pm 5.7^{\circ}$. On the other hand, the uncorrected data imply a declination of $35.4^{\circ} \pm 6.5^{\circ}$ and a declination anomaly of $26.2^{\circ} \pm 6.7^{\circ}$ (Table 2 ). Tectonic conclusions made from these two poles are drastically different; one implies that the Tonga Arc has rotated about $26^{\circ}$, but the other suggests little rotation.

The late Miocene data behave differently than the older data. The scatter appears to be greater, similar to the total data set, and poles calculated with and without bed-dip corrections are indistinguishable (Fig. 11 and Table 2), probably because the late Miocene sediments are tilted less. In addition, reversed polarity samples are present in the late Miocene subset, unlike the older subset, and they give a significantly different pole position than the normal polarity data. The reversed VGPs are mainly located at low latitudes (Fig. 11) and if analyzed by themselves give a pole location near $-37^{\circ}$ to $-39^{\circ}$ (Table 2 ). If the reversed VGPs are removed, the remaining normal VGPs scatter from the South Pole to the equator, but with a definite clustering near the geographic pole. This cluster is in the same location as that of the early Miocene poles, so we used the early Miocene mean 

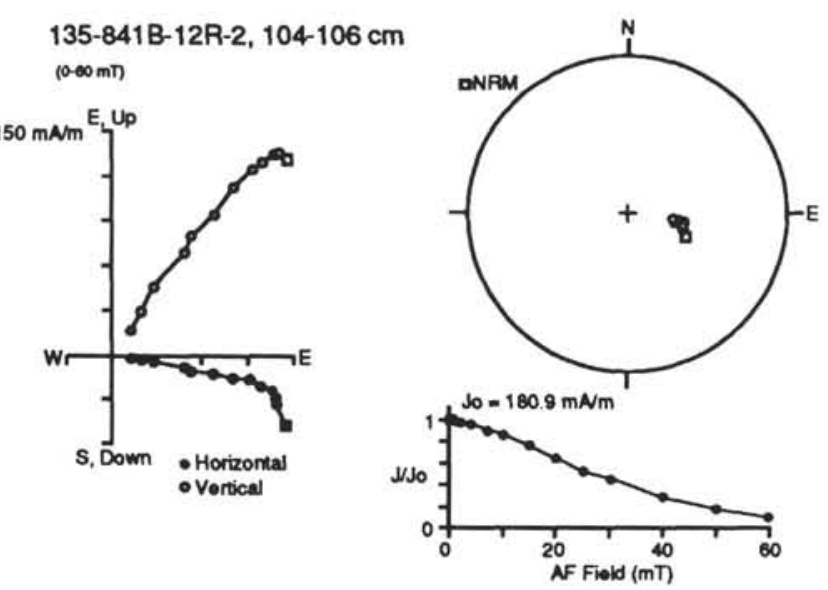

135-841B-18R-1, 105-107 cm (0.60 mT)
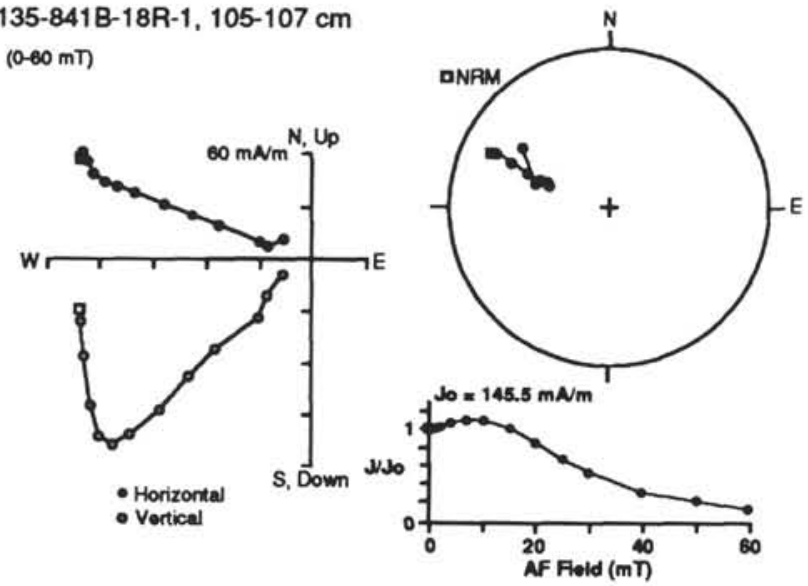
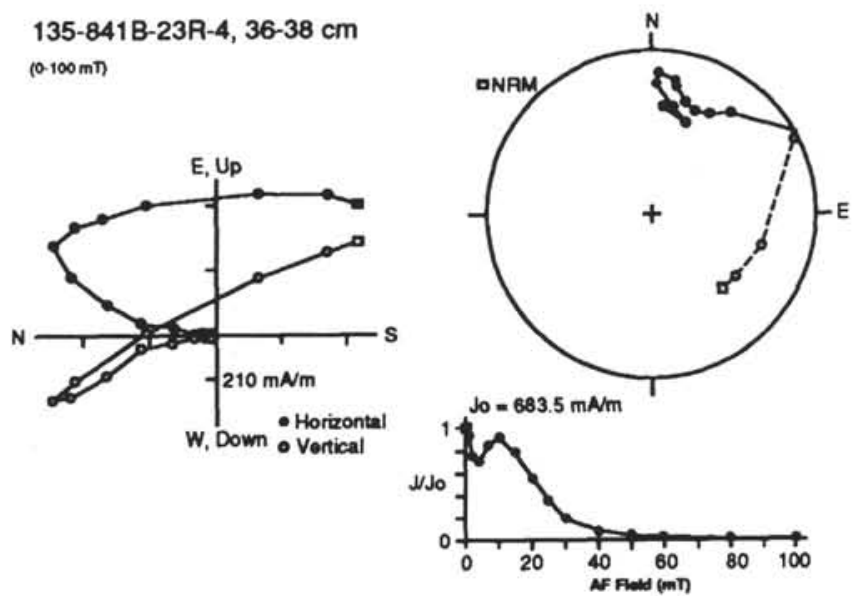

135-841B-37R-4, $89-91 \mathrm{~cm}$
$(0-60 \mathrm{mT})$
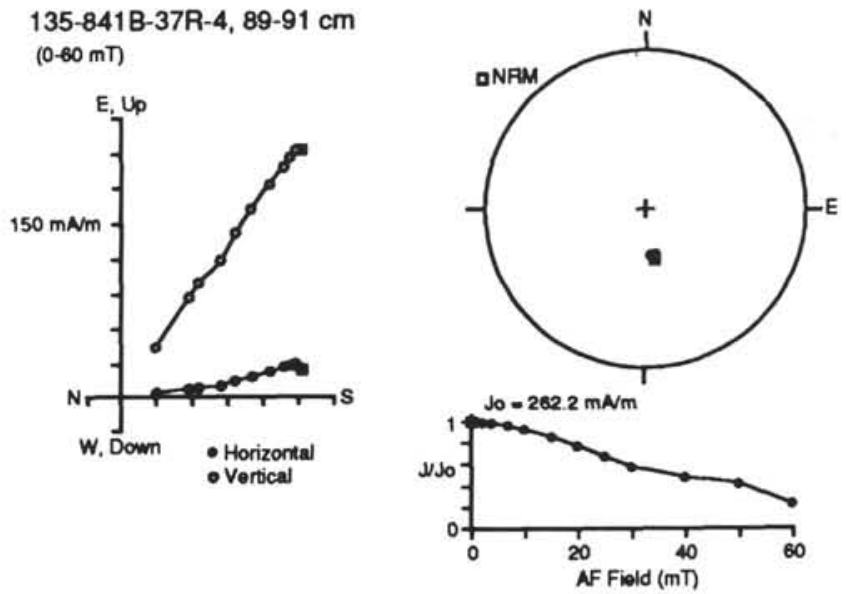

Figure 8. Stepwise AF demagnetization behavior of four representative oriented samples from Hole 841B. Plot conventions as in Figure 3.

Table 3. Reference poles.

\begin{tabular}{|c|c|c|c|c|c|}
\hline \multirow[b]{2}{*}{$\begin{array}{l}\text { Age } \\
\text { (Ma) }\end{array}$} & \multicolumn{2}{|c|}{ Pole location } & \multirow[b]{2}{*}{$N$} & \multirow[b]{2}{*}{$\alpha_{95}$} & \multirow[b]{2}{*}{$k$} \\
\hline & $\begin{array}{l}\text { Latitude } \\
\left({ }^{\circ} \mathrm{N}\right)\end{array}$ & $\begin{array}{c}\text { Longitude } \\
\left({ }^{\circ} \mathrm{E}\right)\end{array}$ & & & \\
\hline \multicolumn{6}{|c|}{ Australia APWP: } \\
\hline 2.9 & -83.2 & 103.6 & 14 & 6.2 & 42.5 \\
\hline 12.0 & -77.2 & 123.5 & 30 & 4.2 & 40.7 \\
\hline 26.0 & -68.4 & 118.7 & 20 & 4.8 & 47.8 \\
\hline \multicolumn{6}{|c|}{ Hotspot APWP: } \\
\hline 2 & -88.7 & 124.3 & & & \\
\hline 4 & -87.3 & 124.6 & & & \\
\hline 6 & -86.0 & 124.9 & & & \\
\hline 8 & -84.6 & 125.1 & & & \\
\hline 10 & -83.3 & 125.4 & & & \\
\hline 12 & -82.3 & 124.9 & & & \\
\hline 14 & -81.2 & 124.5 & & & \\
\hline 16 & -80.2 & 124.3 & & & \\
\hline 18 & -79.2 & 124.2 & & & \\
\hline 20 & -78.2 & 124.1 & & & \\
\hline
\end{tabular}

Notes: Australian APWP data from Idnurm (1985), and Hotspot APWP data from Gordon and Jurdy (1986). N $=$ number of independent samples, $\alpha_{95}=$ radius of cone of $95 \%$ confidence about mean pole, and $k=$ precision parameter.

pole (M, Table 2) and $\Theta_{95}$ to divide the late Miocene normal VGPs into two groups. Most VGPs fall within the $\Theta_{95}$ circle and give a pole position indistinguishable from the early Miocene corrected data (Table 2). The remainder are consistent with the reversed VGPs (Fig. 11). The failure of these samples to pass a reversal test implies that an overprint has not been removed. The observations that most of the normal VGPs give a pole similar to the older, early Miocene data and that they are smeared from the mean reversed pole to this pole suggests that most of the normal VGPs record an overprint. The reversed polarity samples and a few normal polarity samples may not be overprinted and therefore yield VGPs at low latitude.

\section{DISCUSSION}

Our main purpose in undertaking this study was to quantify the amount of rotation of the Tonga Arc and to constrain the timing of the Lau Basin opening. To do this, we proposed determining paleomagnetic vectors from the arc and comparing them to expected directions. Choosing a reference direction is made more difficult by the complex tectonics of the southwest Pacific; however, most investigators have concluded that the Lau Ridge has remained part of the Indo-Australian Plate since the formation of the South Fiji Basin in Oligocene time (Watts et al., 1977; Malahoff, Feden, and Fleming, 1982; Taylor and Karner, 1983; Kroenke, 1984). Thus, we should be able to compare the Tonga Arc magnetic vectors with those from the Indo-Australian Plate.

Unfortunately, the apparent polar wander path (APWP) for the Indo-Australian Plate is not well constrained, particularly for late Tertiary time. Many of the data used to locate the Australian APWP are undated (Embleton, 1981; Idnurm, 1985; Musgrave, 1989). Only a few reliable, dated paleomagnetic poles are available (Table 3). A 2.9-Ma pole from the Newer volcanics and Werriko limestone is located a distance of $6.8^{\circ}$ from the South Pole. Poles from the Glenample formation/Port Campbell limestone and Point Addis limestone are $12.8^{\circ}$ and $21.6^{\circ}$ from the pole and have ages of 12 and 16 $\mathrm{Ma}$, respectively. All three of these poles lie along the $120^{\circ}$ meridian (Fig. 12) and suggest rapid Tertiary polar wander (Idnurm, 1985). 

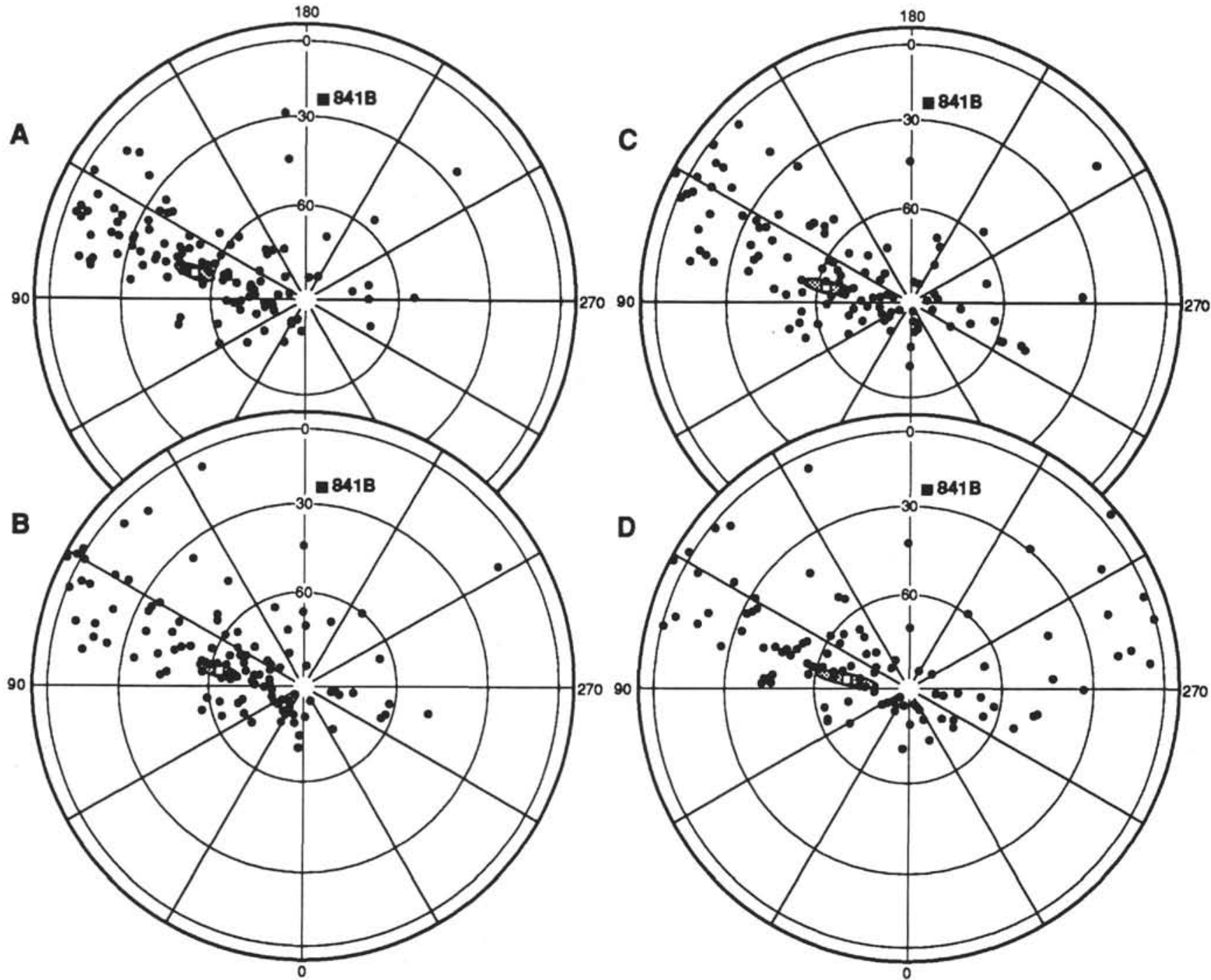

Figure 9. VGPs and mean poles of all oriented samples, Hole 841B. A. VGPs calculated by reorienting beds or faults within sample to individual FMS features, but with no bed-dip corrections. B. VGPs calculated by reorienting beds or faults with individual FMS feature azimuths, with dip-correction from dip of sample beds. C. VGPs calculated using core-average dip and dip-direction from FMS logs for azimuth orientation and dip-correction. D. VGPs calculated by reorienting sample bedding to core-average FMS bed-dip direction and making dip-correction from dip of beds in sample. Mean pole positions shown by open square and surrounded by stippled $95 \%$ confidence ellipse. Solid square = location of drill site. All maps are equal-area plots of the Southern Hemisphere.

Another source of reference poles is to use a model of the drift of the Indo-Australian Plate relative to the hotspots to backtrack the South Pole and construct a predicted APWP. We used the recent plate motion model of Gordon and Jurdy (1986) for these calculations (Table 3), but most models (e.g., Duncan, 1981) have similar rotation parameters for the late Tertiary and give similar results.

The hotspot APWP shows far less rapid polar wander, accumulating only $11.8^{\circ}$ of distance from the South Pole in $20 \mathrm{Ma}$ (Fig. 12). The difference in polar wander rates between hotspot and paleomagnetic studies may result in part from the small number of dated poles (Musgrave, 1989) and in part because of long-term nondipole components in the geomagnetic field (Idnurm, 1986). The nondipole field bias depends on latitude and age, but typically it is about $5^{\circ}$ or less for the late Tertiary (Livermore et al., 1983; Idnurm, 1986). Furthermore, models of the paleofield geometry indicate that the nondipole fields are probably axi-symmetric, which means that they should primarily affect paleomagnetic inclination. Nondipole field-biased paleomagnetic data from the Australian continent may indicate more apparent polar wander because the APWP trends toward the continent (Fig. 12). On the other hand, the Lau Basin is in a direction nearly perpendicular to the APWP trend, so nondipole fields will not strongly affect the separation of Leg 135 paleopoles and the South Pole. Because the Australian APWP is not well constrained and may be biased by nondipole fields, which themselves may not be modeled well, we prefer to compare the Leg 135 paleomagnetic poles to the hotspot APWP.

\section{APC Pole}

Interpretation of the APC pole seems relatively straightforward. Most of the data comes from Hole $840 \mathrm{C}$, which contains no evidence to suggest that these sediments are tilted or metamorphosed. Hole $841 \mathrm{~A}$ samples may have been tilted, but the corrections have little effect on the mean pole position. Likewise, no evidence was found that the sediments cored with the APC in Hole 841A were metamorphosed. Furthermore, the APC core sediments pass a reversal test. All of these factors imply that the APC mean is a reliable pole.

Oriented samples from Holes $840 \mathrm{C}$ and $841 \mathrm{~A}$ all appear to range in age from early to late Pliocene. Biostratigraphic markers indicate 


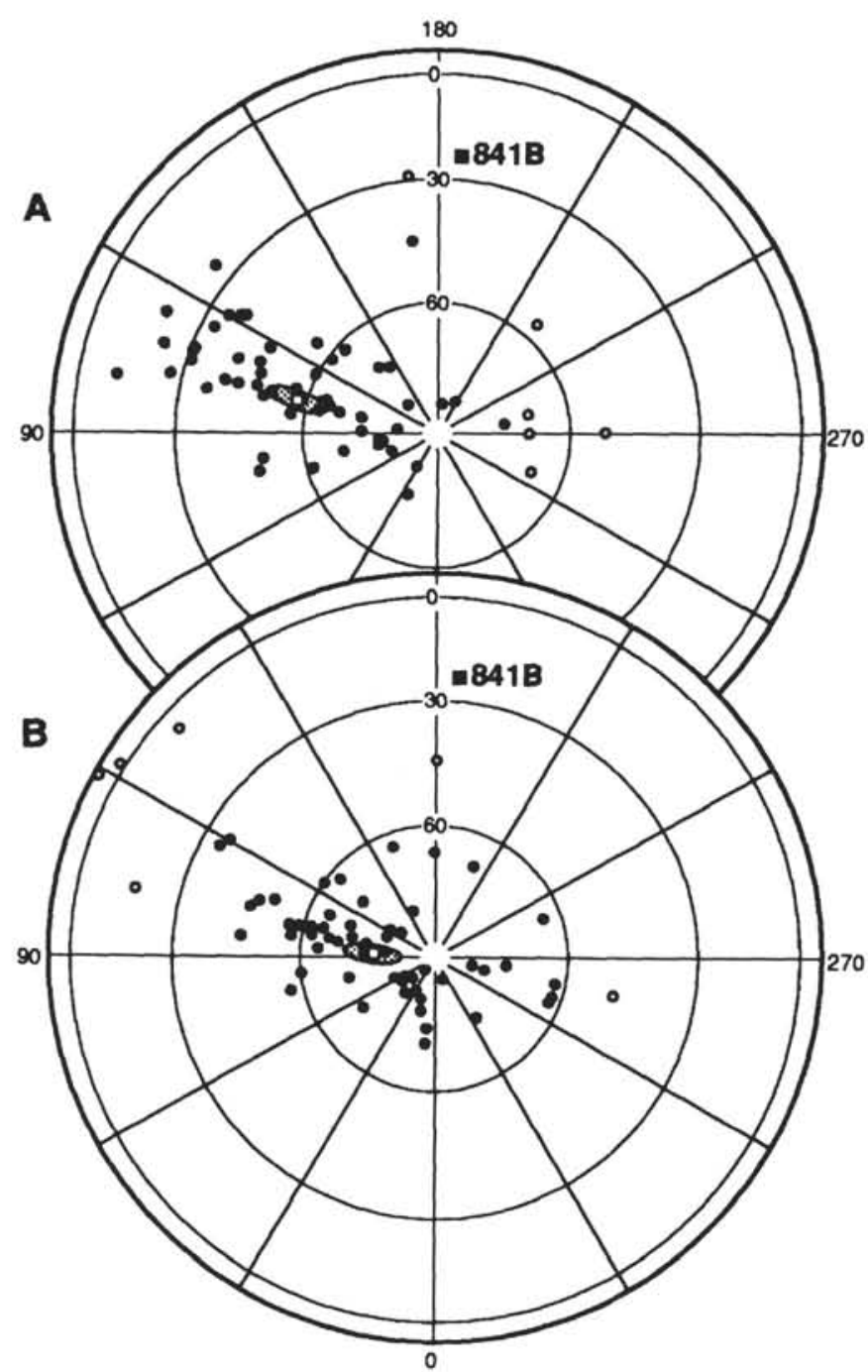

Figure 10. VGPs and mean poles for early Miocene oriented samples, Hole 841B. A. VGPs calculated by reorienting beds or faults in samples to FMS feature azimuths, but with no bed-dip corrections. B. Same as Figure 10A, but with dip-corrections made from sample bed dips. Open symbols $=$ outlier VGPs. Other conventions as in Figure 9.

that Cores $135-840 \mathrm{C}-2 \mathrm{H}$ through $-4 \mathrm{H}$ were deposited during the time represented by calcareous nannoplankton Zone CN12, centered on about $2.7 \mathrm{Ma}$, whereas Cores $135-840 \mathrm{C}-5 \mathrm{H}$ through - $10 \mathrm{H}$ were deposited during Subzone CN10b, centered on $4.8 \mathrm{Ma}$ (Parson, Hawkins, Allan, et al., 1992). All of the Hole $840 \mathrm{C}$ paleomagnetic data are normally magnetized (Appendix B), but this is consistent with the correlation of the Gauss normal polarity epoch (Subchron 2A, 2.48$3.40 \mathrm{Ma}$ ) to the lower part of Zone $\mathrm{CN} 12$ and the Thvera polarity event (a subchron of Chron 3, 4.57-4.77 Ma) to Subchron CN10b (Berggren et al., 1985). The dating of the cores from Hole 841A are less certain because the sediments are barren, but magnetic stratigraphy implies an early Pliocene age (Parson, Hawkins, Allan, et al., 1992). Considering the distribution of ages, we take $4 \mathrm{Ma}$ for the age of the APC pole.

The paleodeclination for the APC pole is $23.0^{\circ} \pm 12.5^{\circ}$, that for the reference pole is $2.6^{\circ} \pm 1.8^{\circ}$, and the implied declination anomaly is $20.4^{\circ} \pm 12.6^{\circ}$ (Fig. 13). To derive error limits, we used $2^{\circ}$ for the $95 \%$ error in predicted pole position, the major semi-axis length of the APC pole $95 \%$ confidence ellipse, and followed the methods of Beck (1980) and Demarest (1983). The former error estimate seemed reasonable given that hotspot volcanic tracks can usually be located within a degree of distance; the latter is appropriate because the major

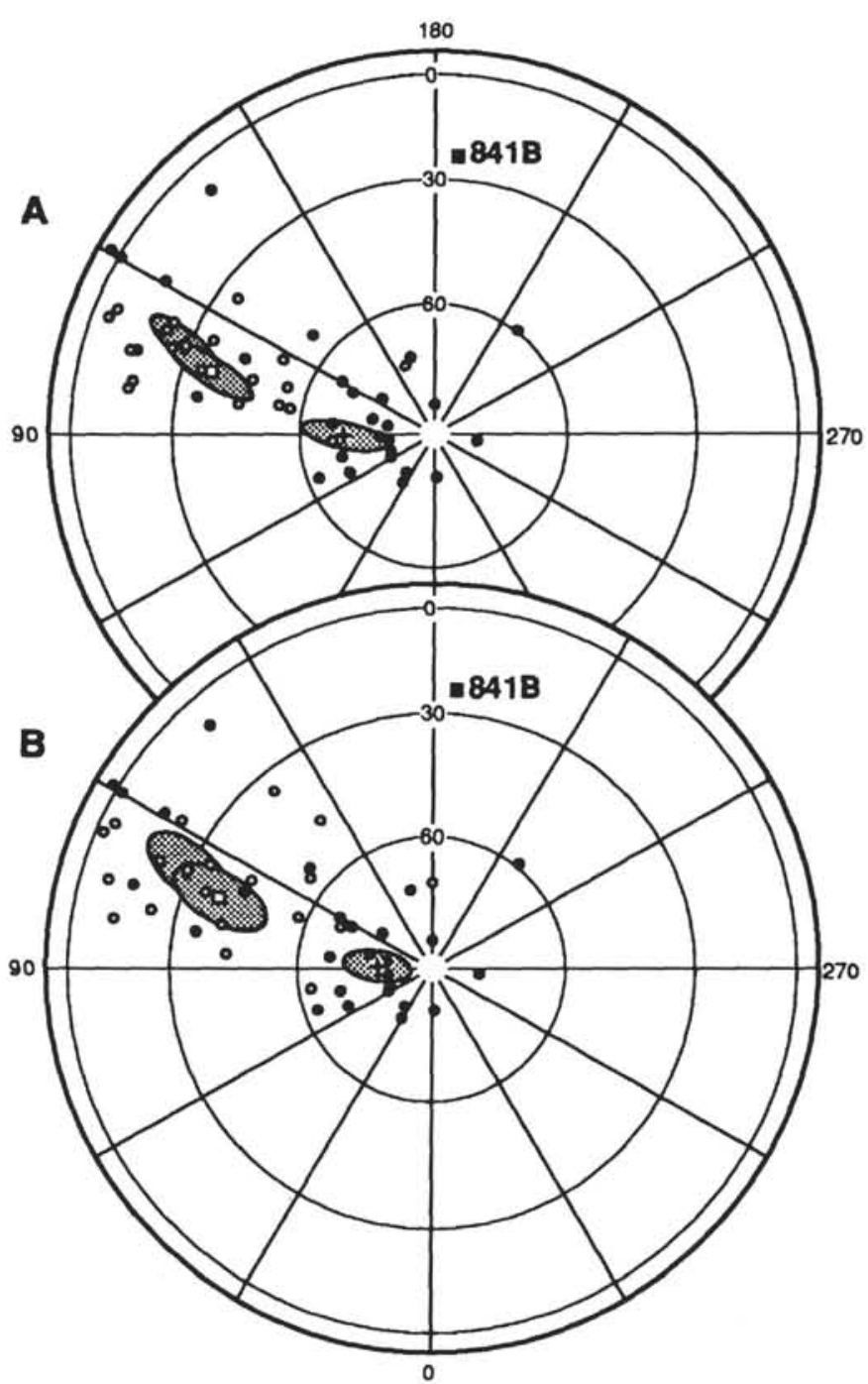

Figure 11. VGPs and mean poles for late Miocene oriented samples, Hole 841B. A. VGPs calculated by reorienting beds or faults in samples to FMS feature azimuths, but with no bed-dip corrections. B. Same as Figure 11A, but with bed-dip corrections from sample bed dips. Open symbols = VGPs from reversed-polarity samples. Plus sign, open square, and open diamond = pole positions for high-latitude normal, reversed-polarity, and low-latitude normalpolarity VGPs, respectively (see text and Table 2). Other conventions as in Figure 9.

semi-axis of the APC pole confidence ellipse trends toward the reference pole (Fig. 12). The APC core declination anomaly is indistinguishable from the $17^{\circ}$ of clockwise rotation expected from the trends of the Tonga and Lau ridges. Additionally, the paleolatitude indicated by the APC pole, $-27.9^{\circ} \pm 2.3^{\circ}$, compares well to the expected paleolatitude, $-24.0^{\circ} \pm 1.6^{\circ}$, suggesting that the rotation was mainly about a vertical axis. These observations imply that the Lau Ridge and Tonga Arc have separated like the blades of a pair of scissors, rotating about a nearby hinge (pole of rotation). Furthermore, the youngest, oriented APC cores are of Subchron 2A age and their paleopoles are indistinguishable from the paleopoles of older APC cores (Table 1). Although confidence in this observation must be low because of the orientation errors and small number of oriented cores, it implies that rotation began at the time of Subchron $2 \mathrm{~A}$ or later. This is consistent with the oldest magnetic anomalies at the edges of the Lau Basin being identified as Subchron 2A(Weissel, 1977; Malahoff, Feden, and Fleming, 1982) rather than as Subchron $3 \mathrm{~A}$ as suggested by some investigators (Parson, Hawkins, Allan, et al., 1992). 


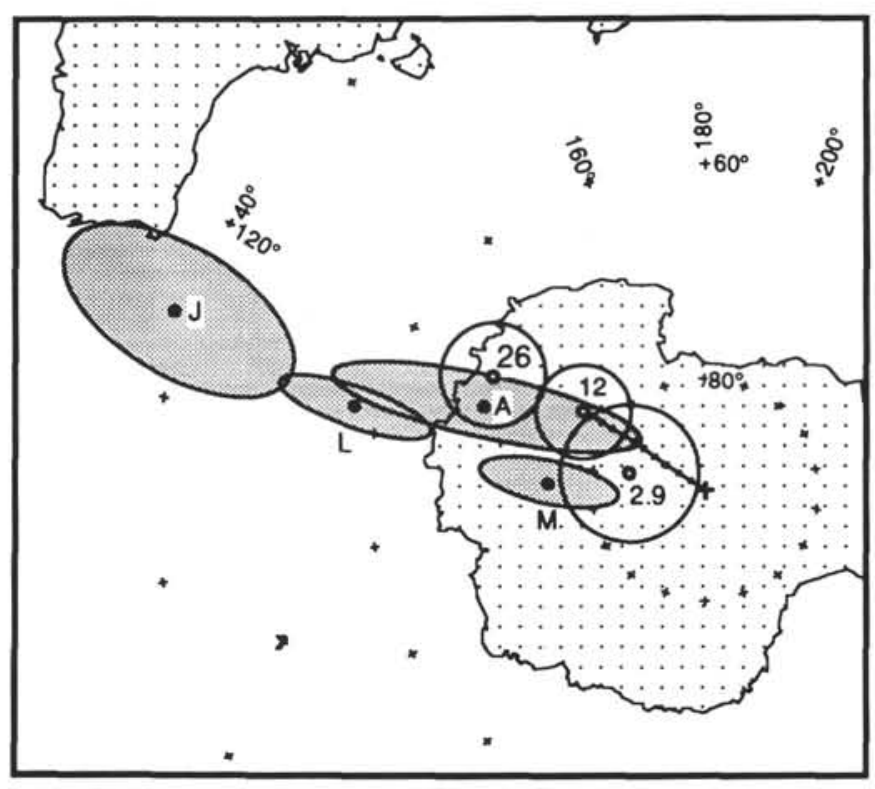

Figure 12. Comparison of paleomagnetic poles from Tonga Arc with those from Indo-Australian Plate. Filled circles $=$ mean pole positions from Tonga Arc, with letters identifying poles (Table 2). Open circles = paleomagnetic poles from Australia (Idnurm, 1985; Table 3), labeled by age (in Ma). Small squares connected by a line with the South Pole $=$ apparent polar wander path for the Indo-Australian Plate predicted from the relative motion of the plate vs. hotspots (Gordon and Jurdy, 1980); squares at 2-m.y. intervals. Outlines of Australia and Antarctica, in their present positions, are shown for reference. Map is an equal-area plot of the Southern Hemisphere.

\section{Hole 841B Poles}

In contrast to the APC cores, interpretation of the Hole 841B data is complicated by uncertainties about overprints and corrections for tectonic tilting. The late Miocene VGPs failed a reversal test, and their distribution implies a normal polarity overprint. Such an overprint is a possibility because shipboard studies showed that within $100 \mathrm{~m}$ beneath the fault zone at 449 mbsf sediments had been clearly affected by low-temperature hydrothermal metamorphism (Parson, Hawkins, Allan, et al., 1992). This zone includes Cores 135-841B-31R through $-41 \mathrm{R}$, from which $90 \%-95 \%$ of the early Miocene samples were taken. Moreover, all of these samples are of normal polarity, which results, perhaps, because of remagnetization of the entire zone within a single polarity chron. Although shipboard descriptions suggest that the overlying sediments were not as clearly affected by metamorphism, roughly half of the VGPs from Cores 135-841B-2R to -29R have directions consistent with the early Miocene data, implying that hydrothermal metamorphism may have affected much of the sediment column.

The reversed polarity samples suggest that some of the sediments from the late Miocene section may have escaped remagnetization. The late Miocene sediments contain calcareous nannoplankton from Subzone CN8b (Parson, Hawkins, Allan, et al., 1992), the center of which is at about 8.6 Ma (Berggren et al., 1985). A declination anomaly of $51.1^{\circ} \pm 11.5^{\circ}$ was found by comparing the reversed polarity pole $(\mathrm{J}$, Table 2) made with structural corrections, which has a declination of $56.7^{\circ} \pm 11.4^{\circ}$, with the expected declination of $5.6^{\circ} \pm 1.8^{\circ}$ (Fig. 12). The pole calculated without structural corrections (G, Table 2$)$ is not significantly different, so it yields a similar result. As was true for the APC cores, these data show little inclination anomaly: pole $J$ implies a paleolatitude of $-25.9^{\circ} \pm 4.1^{\circ}$, nearly the same as the expected paleolatitude, $-26.2^{\circ} \pm 1.6^{\circ}$. Although these observations once again imply rotation about a vertical axis, the declination anomaly is nearly three times the expected $17^{\circ}$ angle of deflection. Either this pole position is incorrect or local tectonics affected the Tonga Arc at the site. Large
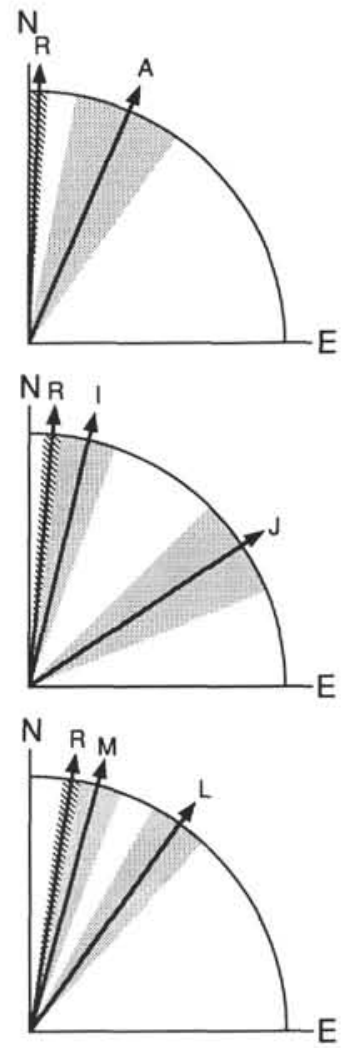

Figure 13. Comparison of paleodeclinations with expected declination values, Sites 840 and 841 . Paleodeclination values were determined from paleomagnetic poles (Table 2); expected declination values were calculated from synthetic apparent polar wander path derived from motion of the Indo-Australian Plate relative to the hotspots (Table 3 ). Plot at top shows the APC core mean declination; plot in middle shows late Miocene declinations from Hole 841B; plot at bottom shows early Miocene declinations from Hole 841B. Arrows $=$ the reference declination, R, and paleodeclinations (labels correspond to poles in Table 2 and Fig. 12). Hachured and stippled sectors show $95 \%$ confidence regions.

local rotations within island arcs are not without precedent and may result from tectonic collisions (e.g., McCabe, 1984; Keating and Helsley, 1985). Because Site 841 is located on the forearc of the Tonga Ridge, it may have been particularly susceptible to tectonic deformation.

Drawing a tectonic conclusion from the early Miocene pole is complicated by the addition of a large dependence of pole position on bed-dip corrections (Fig. 12). Cores 135-841B-32R through-41R have calcareous nannoplankton indicative of biostratigraphic Zone CN4, which has a central age of $15.3 \mathrm{Ma}$ (Berggren et al., 1985). The appropriate reference declination is $9.2^{\circ} \pm 1.8^{\circ}$, so poles without (L) and with $(\mathrm{M})$ bed-dip corrections give anomalies of $26.2^{\circ} \pm 6.7^{\circ}$ and $5.7^{\circ}$ $\pm 5.7^{\circ}$, respectively. Both poles give similar paleolatitude values, $-25.0^{\circ} \pm 1.5^{\circ}(\mathrm{L})$ and $-22.7^{\circ} \pm 1.6^{\circ}(\mathrm{M})$, which are not very different from the predicted paleolatitude of $-27.7^{\circ} \pm 1.6^{\circ}$, so again the difference is primarily in declination.

Two possible hypotheses can be formulated from these observations. On the one hand, if the pole calculated without bed-dip corrections (L; Fig. 12) is correct, it indicates $26.2^{\circ}$ of rotation, which is approximately the same amount as the APC pole. These sediments could have been remagnetized by a hydrothermal event at the time the Tonga Arc began to separate from the Lau Ridge. If this occurred during Subchron $2 \mathrm{~A}$, the normal polarity of the overprint would be explained. An alternate hypothesis is that the pole calculated from samples corrected for bed-dips is better. It implies a declination that is virtually indistinguishable from the expected direction, as if the sediments were remagnetized recently. Remagnetization during the 
Brunhes polarity epoch (since $0.73 \mathrm{Ma}$ ) could account for the normal polarity, but if correct, this implies that the stratal dips mostly developed recently. One significant tectonic event during The Brunhes period is the subduction of parts of the Louisville Ridge beneath the arc. At Site 841, this would have occurred about $0.5-1.0 \mathrm{Ma}$ (MacLeod, this volume). Without additional data, we cannot decide with certainty which hypothesis is best.

\section{CONCLUSIONS}

Analysis of paleomagnetic data from oriented APC cores from Holes $840 \mathrm{C}$ and $841 \mathrm{~A}$ and samples from Hole $841 \mathrm{~B}$, oriented relative to the FMS wireline logs, yielded paleopoles from close to the South Pole to the equator, trending along the $110^{\circ}$ meridian. The scatter in pole latitudes apparently results from several factors: the Australian APWP trends along this meridian, core-orientation error causes scatter in this direction, and Tonga Arc rotation has moved the poles in the same direction. In addition, structural corrections for bed dips, many of which trend perpendicular to the Tonga Trench, also move paleomagnetic poles along this meridian.

The scatter of APC core poles implies a mean orientation error of $18.6^{\circ}$ (standard deviation). This value is probably inflated by a problem with the lithology of Hole $840 \mathrm{C}$, which caused the possibility of core rotation within the core liner. The scatter of sample declinations reoriented relative to the FMS logs was variable and depended on the groupings of samples by age and polarity. Declination-mean standard deviations ranged from $15.7^{\circ}$ to $31.9^{\circ}$, with higher values such as the latter probably including a significant component of tectonic rotation and apparent polar wander.

The mean APC pole, with an age of $4 \mathrm{Ma}$, is located at $-69.0^{\circ} \mathrm{N}$, $112.2^{\circ} \mathrm{E}$, with a $95 \%$ error ellipse having a minor semi-axis of $2.9^{\circ}$ and a major semi-axis of $14.2^{\circ}$ with an azimuth of $352^{\circ}$. This pole gives a paleodeclination of $23.0^{\circ} \pm 12.5^{\circ}$. When compared with an APWP predicted from plate-hotspot motion, it implies a declination anomaly of $20.8^{\circ} \pm 12.6^{\circ}$. Because the paleolatitude is nearly the same as the expected value, this anomaly implies that the sites have rotated clockwise around a vertical axis. This anomaly and sense of rotation are those expected if the Tonga Arc rotated away from the Lau Ridge as a more or less rigid body. The youngest cores used to calculate this pole (Cores $135-840 \mathrm{C}-2 \mathrm{H}$ through $-4 \mathrm{H}$ ) all have declinations indistinguishable from the rest, despite their Gauss Epoch age (Subchron $2 \mathrm{~A}, 2.48-3.40 \mathrm{Ma})$. This observation suggests that most of the tectonic rotation has occurred since these sediments were deposited. The large mean scatter of APC pole declinations, however, indicates that this conclusion must be taken with a degree of caution.

Interpretation of paleopoles from Site 841 was complicated by the vertical tectonics and overprints. Many of the sediments were hydrothermally altered. Because normal and reversed samples yielded significantly different pole positions, it appears that many are overprinted. A pole calculated from late Miocene (age $8.6 \mathrm{Ma}$ ) reversed-polarity data, which may be relatively free of overprint, is located at $-38.7^{\circ} \mathrm{N}$, $109.3^{\circ} \mathrm{E}$ and has a $95 \%$ confidence ellipse with a minor semi-axis of $5.1^{\circ}$ and a major semi-axis of $12.8^{\circ}$ with an azimuth of $10^{\circ}$. This pole has a paleodeclination of $56.7^{\circ} \pm 11.4^{\circ}$, giving a declination anomaly of $51.1^{\circ} \pm 11.5^{\circ}$. As before, no significant anomaly occurs in paleolatitude, implying a vertical axis rotation. However, this rotation is much greater than that expected from the geometry of the Tonga Arc. Early Miocene paleopoles are highly dependent on structural corrections. A pole calculated from data not corrected for bed dips is located at $-57.7^{\circ} \mathrm{N}, 104.0^{\circ} \mathrm{E}$, and has an error ellipse with semi-axes of $1.9^{\circ}$ and $7.5^{\circ}$, with a major axis azimuth of $5^{\circ}$. A pole calculated from the same data corrected for bed dips is located much closer to the geographic pole, at $-76.2^{\circ} \mathrm{N}, 93.0^{\circ} \mathrm{E}$, and has an error ellipse with semi-axes of $2.0^{\circ}$ and $6.3^{\circ}$, with the latter having an azimuth of $8^{\circ}$. The two poles yield declination anomalies of $26.2^{\circ} \pm 6.7^{\circ}$ and $5.7^{\circ} \pm 5.7^{\circ}$, respectively. One could be interpreted to indicate an amount of rotation similar to that of the APC core pole, the other, to suggest little rotation.

\section{ACKNOWLEDGMENTS}

We thank Fred Vine and Simon Allerton for constructive reviews. The senior author thanks JOI/USSAC for project support. This is Texas A\&M Geodynamics Research Institute Contribution No. 90.

\section{REFERENCES $*$}

Auzende, J.-M., Lafoy, Y., and Marsset, B., 1988. Recent geodynamic evolution of the north Fiji Basin (southwest Pacific). Geology, 16:925-929.

Beck, M.E., Jr., 1980. Paleomagnetic record of plate-margin tectonic processes along the western edge of North America. J. Geophys. Res., 85:7115-7131.

Berggren, W.A., Kent, D.V., Flynn, J.J., and Van Couvering, J.A., 1985. Cenozoic geochronology. Geol. Soc. Am. Bull., 96:1407-1418.

Cox, A., and Gordon, R.G., 1984. Paleolatitudes determined from paleomagnetic data from vertical cores. Rev. Geophys. Space Phys., 22:42-72.

Demarest, H.H., Jr., 1983. Error analysis for the determination of tectonic rotation from paleomagnetic data. J. Geophys. Res., 88:4321-4328.

Duncan, R.A., 1981. Hotspots in the southern oceans-an absolute frame of reference for motion of the Gondwana continents. In Solomon, S.C., Van der Voo, R., and Chinnery, M.A. (Eds.), Quantitative Methods of Assessing Plate Motions. Tectonophysics, 74:29-42.

Embleton, B.J.J., 1981. A review of the paleomagnetism of Australia and Antarctica. In McElhinny, M.W., and Valencio, D.A. (Eds.), Paleoreconstruction of the Continents. Am. Geophys. Union, Geodyn. Ser., 2:77-92.

Falvey, D.A., 1978. Analysis of paleomagnetic data from the New Hebrides. Bull. Aust. Soc. Explor. Geophys., 9:117-123.

Fisher, R.A., 1953. Dispersion on a sphere. Proc. R. Soc. London A, 217:295305.

Gordon, R.G., and Cox, A., 1980. Calculating paleomagnetic poles for oceanic plates. Geophys. J. R. Astron. Soc., 63:619-640.

Gordon, R.G., and Jurdy, D.M., 1986. Cenozoic global plate motions. J. Geophys. Res., 91:12389-12406.

Hamburger, M.W., and Isaacs, B.L., 1988. Diffuse backarc basin deformation in the southwestern Pacific. Nature, 332:599-604.

Hawkins, J.W., 1974. Geology of the Lau Basin, a marginal sea behind the Tonga Arc. In Burke, C., and Drake, C. (Eds.), The Geology of Continental Margins: Berlin (Springer-Verlag), 505-520.

Idnurm, M., 1985. Late Mesozoic and Cenozoic palaeomagnetism of Australia-I. A redetermined apparent polar wander path. Geophys. J. R. Astron. Soc., 83:399-418.

_ 1986. Late Mesozoic and Cenozoic paleomagnetism of AustraliaIII. Bias-corrected pole paths for Australia, Antarctica and India. Geophys. J. R. Astron. Soc., 86:277-287.

James, A., and Falvey, D.A., 1978. Analysis of palaeomagnetic data from Viti Levu, Fiji. Bull. Aust. Soc. Explor: Geophys., 9:115-117.

Karig, D.E., 1970. Ridges and basins of the Tonga-Kermadec island arc system. J. Geophys. Res., 75:239-254.

Karlin, R., and Levi, S., 1985. Geochemical and sedimentological control of the magnetic properties of hemipelagic sediments. J. Geophys. Res., 90:10373-10392.

Keating, B.H., and Helsley, C.E., 1985. Implications of island arc rotations to the studies of marginal terranes. J. Geodyn., 2:159-181.

Kroenke, L., 1984. Cenozoic Development of the Southwest Pacific. U.N. Econ. Soc. Comm. Asia Pac., Suva, Fiji. CCOP/SOPAC, Tech. Bull., 6.

Livermore, R.A., Vine, F.J., and Smith, A.G., 1983. Plate motions and the geomagnetic field. I. Quaternary and late Tertiary. Geophys. J. R. Astron. Soc., 73:153-171.

MacLeod, C.J., Parson, L.M., Sager, W.W., and ODP Leg 135 Scientific Party, 1992. Identification of tectonic rotations in boreholes by the integration of core information with Formation MicroScanner and Borehole Televiewer images. In Hurst, A., Griffiths, C.M., and Worthington, P.F. (Eds.) Geological Applications of Wireline Logs II. Geol. Soc. Spec. Publ. London, 65:235-246.

Malahoff, A., Feden, R.H., and Fleming, H.S., 1982. Magnetic anomalies and tectonic fabric of marginal basins north of New Zealand. J. Geophys. Res., $87: 4109-4125$.

Malahoff, A., Hammond, S.R., Naughton, J., Keeling, D.L., and Richmond, R.N., 1982. Geophysical evidence for post-Miocene rotation of the island

\footnotetext{
Abbreviations for names of organizations and publication titles in ODP reference lists follow the style given in Chemical Abstracts Service Source Index (published by American Chemical Society).
} 
of Viti Levu, Fiji, and its relationship to tectonic development of the North Fiji Basin. Earth Planet. Sci. Lett., 57:398-414.

Malahoff, A., Kroenke, L.W., Cherkis, N., and Brozena, J., in press. Magnetic and tectonic fabric of the North Fiji Basin and Lau Basin. In Kroenke, L., and Eade, J.V. (Eds.), Basin Formation, Ridge Crest Processes, and Metallogenesis in the North Fiji Basin. Circum-Pac. Counc. Energy Miner. Resour., Earth Sci. Ser.

McCabe, R., 1984. Implications of paleomagnetic data on the collision related bending of island arcs. Tectonics, 3:409-428.

McFadden, P.L., 1980. Determination of the angle in a Fisher distribution which will be exceeded with a given probability. Geophys. J. R. Astron. Soc., 60:391-396.

Musgrave, R.J., 1986. Palaeomagnetism and tectonics of the eastern Solomon islands [Ph.D. dissert.]. Univ. of Sydney, Sydney, Australia. 1989. A weighted least-squares fit of the Australian apparent polar wander path for the last 100 Myr. Geophys. J. R. Astron. Soc., 96:231-243. , 1990. Paleomagnetism and tectonics of Malaita, Solomon Islands. Tectonics, 9:735-759.

Parson, L., Hawkins, J., Allan, J., et al., 1992. Proc. ODP, Init. Repts., 135: College Station, TX (Ocean Drilling Program).

Parson, L.M., Pearce, J.A., Murton, B.J., Hodkinson, R.A., Bloomer, S., Ernewein, M., Huggett, Q.J., Miller, S., Johnson, L., Rodda, P., and Helu,
S., 1990. Role of ridge jumps and ridge propagation in the tectonic evolution of the Lau back-arc basin, southwest Pacific. Geology, 18:470-473.

Sclater, J.G., Hawkins, J.W., Mammerickx, J., and Chase, C.G., 1972. Crustal extension between the Tonga and Lau Ridges: petrologic and geophysical evidence. Geol. Soc. Am. Bull., 83:505-518.

Tarling, D.H., 1967. The palaeomagnetism of some rock samples from Viti Levu, Fiji. N. Z. J. Geol. Geophys., 10:1235-1247.

Taylor, B., and Karner, G.D., 1983. On the evolution of marginal basins. Rev. Geophys. Space Phys., 21:1727-1741.

Watts, A.B., Weissel, J.K., and Larson, R.L., 1977. Sea-floor spreading in marginal basins of the western Pacific. Tectonophysics, 37:167-181.

Weissel, J.K., 1977. Evolution of the Lau Basin by the growth of small plates. In Talwani, M., and Pitman, W.C., III (Eds.), Island Arcs, Deep Sea Trenches and Back-Arc Basins. Am. Geophys. Union, Maurice Ewing Ser., 1:429-436.

Date of initial receipt: 1 October 1992

Date of acceptance: 25 March 1993

Ms 135SR-119

APPENDIX A

Core-mean Bed-dip Directions, Site 841

\begin{tabular}{|c|c|c|c|c|c|}
\hline Core number & $\begin{array}{l}\text { Dip } \\
\left({ }^{\circ} \mathrm{D}\right)\end{array}$ & $\begin{array}{l}\text { Azimuth } \\
\left({ }^{\circ} \mathrm{E}\right)\end{array}$ & $k$ & $\alpha_{95}$ & $N$ \\
\hline \multicolumn{6}{|l|}{ 135-841A- } \\
\hline $4 \mathrm{H}$ & 10.5 & 21.8 & 181.3 & 5.5 & 6 \\
\hline $5 \mathrm{H}$ & 13.9 & 135.3 & 7.2 & 29.7 & 6 \\
\hline $6 \mathrm{H}$ & 26.0 & 71.1 & 6.2 & 38.4 & 5 \\
\hline $8 \mathrm{H}$ & 6.7 & 75.9 & 10.1 & 51.7 & 3 \\
\hline \multicolumn{6}{|l|}{ 135-841B- } \\
\hline $2 \mathrm{R}$ & 20.3 & 78.4 & 19.9 & 35.3 & 3 \\
\hline $3 \mathrm{R}$ & 11.4 & 82.0 & 15.2 & 17.3 & 7 \\
\hline $4 \mathrm{R}$ & 8.1 & 62.4 & 27.2 & 12.8 & 7 \\
\hline $5 \mathrm{R}$ & 8.2 & 92.4 & 33.5 & 11.5 & 7 \\
\hline $6 \mathrm{R}$ & 10.7 & 48.4 & 11.8 & 19.9 & 7 \\
\hline $7 R$ & 6.6 & 54.2 & 25.1 & 7.5 & 17 \\
\hline 9R & 6.2 & 57.9 & 12.8 & 9.5 & 21 \\
\hline $12 \mathrm{R}$ & 5.8 & 290.6 & 5.8 & 15.2 & 15 \\
\hline $13 R$ & 11.5 & 327.3 & 3.2 & 23.4 & 19 \\
\hline $15 R$ & 10.2 & 53.8 & 20.3 & 6.9 & 24 \\
\hline $16 \mathrm{R}$ & & & & & \\
\hline $\begin{array}{l}\text { Above } 308.85 \text { mbsf } \\
\quad 16 \mathrm{R}\end{array}$ & 7.8 & 57.4 & 221.5 & 9.5 & 13 \\
\hline $\begin{array}{l}\text { Below } 308.85 \text { mbsf } \\
\quad 17 \mathrm{R}\end{array}$ & 8.7 & 328.3 & 16.4 & 12.2 & 11 \\
\hline $\begin{array}{l}\text { Above } 315.67 \mathrm{mbsf} \\
17 \mathrm{R}\end{array}$ & 6.0 & 336.2 & 12.6 & 25.3 & 5 \\
\hline Below $315.67 \mathrm{mbsf}$ & 11.3 & 59.4 & 21.3 & 19.1 & 5 \\
\hline $18 \mathrm{R}$ & 12.9 & 345.6 & 9.7 & 13.4 & 15 \\
\hline $19 \mathrm{R}$ & 24.3 & 292.3 & 10.1 & 35.8 & 4 \\
\hline $20 \mathrm{R}$ & 13.3 & 275.5 & 21.0 & 7.1 & 22 \\
\hline $22 \mathrm{R}$ & 8.4 & 103.5 & 10.7 & 13.3 & 14 \\
\hline $24 \mathrm{R}$ & 3.8 & 221.8 & 19.5 & 35.6 & 3 \\
\hline $29 \mathrm{R}$ & 5.2 & 183.5 & 21.1 & 34.2 & 3 \\
\hline $34 \mathrm{R}$ & 21.0 & 200.0 & & & 1 \\
\hline $35 \mathrm{R}$ & 39.2 & 79.1 & & & 4 \\
\hline $36 \mathrm{R}$ & 27.7 & 128.9 & 30.3 & 13.6 & 6 \\
\hline $37 \mathrm{R}$ & 27.0 & 127.9 & 29.4 & 7.7 & 14 \\
\hline $38 \mathrm{R}$ & 25.4 & 117.0 & 32.8 & 10.5 & 8 \\
\hline $39 \mathrm{R}$ & 22.2 & 128.2 & 61.5 & 3.5 & 29 \\
\hline $40 \mathrm{R}$ & 23.3 & 146.4 & 21.9 & 6.0 & 29 \\
\hline $41 R$ & & & & & \\
\hline $\begin{array}{l}\text { Above } 550.0 \mathrm{mbsf} \\
\quad 41 \mathrm{R}\end{array}$ & 25.9 & 146.9 & 38.5 & 6.5 & 15 \\
\hline Below $550.0 \mathrm{mbsf}$ & 14.8 & 81.2 & 11.2 & 23.1 & 6 \\
\hline $42 \mathrm{R}$ & 15.3 & 88.1 & 11.6 & 26.6 & 5 \\
\hline $43 R$ & 31.2 & 98.5 & 10.0 & 13.8 & 14 \\
\hline $44 \mathrm{R}$ & 39.6 & 96.2 & 65.2 & 13.3 & 4 \\
\hline
\end{tabular}

Notes: Hole $841 \mathrm{~A}$ dips oriented with multishot tool; Hole $841 \mathrm{~B}$ dips oriented with FMS log. "Dip" and "Azimuth" = average dip magnitude and direction, $k=$ precision parameter, $\alpha_{95}=$ radius of $95 \%$ confidence circle, $N=$ number of dip and azimuth measurements used to calculate mean. 
APPENDIX B

APC Core Paleomagnetic Data

\begin{tabular}{|c|c|c|c|c|c|c|c|c|}
\hline $\begin{array}{l}\text { Core, section, } \\
\text { interval }(\mathrm{cm})\end{array}$ & $\begin{array}{l}\text { Depth } \\
\text { (mbsf) }\end{array}$ & $\begin{array}{l}\text { AF step } \\
(\mathrm{mT})\end{array}$ & $N$ & $\begin{array}{c}J_{0} \\
\left(\mathrm{mAm}^{-1}\right)\end{array}$ & $\begin{array}{l}J / J_{0} \\
(\%)\end{array}$ & $\begin{array}{l}\text { Dec } \\
\left({ }^{\circ} \mathrm{E}\right)\end{array}$ & $\begin{array}{l}\text { Inc } \\
\left({ }^{\circ} \mathrm{D}\right)\end{array}$ & $\begin{array}{l}\text { CSD } \\
\left({ }^{\circ}\right)\end{array}$ \\
\hline \multicolumn{9}{|l|}{$135-840 \mathrm{C}$ - } \\
\hline $2 \mathrm{H}-1,27-29$ & 47.77 & $10-40$ & 6 & 25.06 & 0.24 & 43.0 & -40.9 & 1.8 \\
\hline $2 \mathrm{H}-1,48-50$ & 47.98 & $30-50$ & 3 & 45.16 & 0.05 & 70.8 & -41.2 & 2.8 \\
\hline $2 \mathrm{H}-\mathrm{CC}, 7-9$ & 48.09 & $20-50$ & 5 & 15.45 & 0.08 & 52.4 & -35.1 & 6.2 \\
\hline $2 \mathrm{H}-\mathrm{CC}, 18-20$ & 48.20 & $15-40$ & 5 & 33.79 & 0.14 & 22.6 & $-30.6^{*}$ & 1.1 \\
\hline $3 \mathrm{H}-1,10-12$ & 57.10 & $15-40$ & 5 & 421.29 & 0.04 & 24.1 & -62.4 & 1.9 \\
\hline $3 \mathrm{H}-1,21-23$ & 57.21 & $30-40$ & 3 & 172.47 & 0.02 & 48.5 & -64.7 & 1.5 \\
\hline $3 \mathrm{H}-1,30-32$ & 57.30 & $25-40$ & 4 & 141.77 & 0.11 & 33.6 & -54.1 & 0.7 \\
\hline $3 \mathrm{H}-1,49-51$ & 57.49 & $20-40$ & 5 & 41.69 & 0.19 & 47.9 & -40.8 & 0.6 \\
\hline $3 \mathrm{H}-1,103-105$ & 58.03 & $20-40$ & 4 & 117.54 & 0.03 & 358.8 & -69.2 & 5.6 \\
\hline $3 \mathrm{H}-1,109-111$ & 58.09 & $25-40$ & 4 & 69.33 & 0.05 & 24.6 & -37.2 & 3.2 \\
\hline $3 \mathrm{H}-1,114-116$ & 58.14 & $10-25$ & 4 & 81.15 & 0.15 & 16.6 & -46.2 & 2.6 \\
\hline $3 \mathrm{H}-1,140-142$ & 58.40 & $25-50$ & 4 & 193.44 & 0.03 & 71.3 & -56.2 & 3.3 \\
\hline $3 \mathrm{H}-2,105-107$ & 59.55 & $20-40$ & 4 & 208.04 & 0.03 & 33.2 & -57.8 & 1.8 \\
\hline $3 \mathrm{H}-2,110-112$ & 59.60 & $20-35$ & 4 & 113.67 & 0.05 & 28.1 & -57.6 & 1.8 \\
\hline $3 \mathrm{H}-2,120-122$ & 59.70 & $20-50$ & 5 & 500.89 & 0.04 & 34.0 & -47.4 & 1.1 \\
\hline $4 \mathrm{H}-1,10-12$ & 66.60 & $15-30$ & 4 & 58.69 & 0.16 & 5.4 & -37.4 & 1.9 \\
\hline $4 \mathrm{H}-2,93-95$ & 68.93 & $30-50$ & 3 & 19.74 & 0.14 & 11.9 & -46.8 & 5.3 \\
\hline $4 \mathrm{H}-2,133-135$ & 69.33 & $20-50$ & 5 & 37.55 & 0.09 & 23.4 & -33.6 & 4.4 \\
\hline $4 \mathrm{H}-3,10-12$ & 69.60 & $20-50$ & 5 & 114.13 & 0.11 & 33.9 & -38.4 & 1.8 \\
\hline $4 \mathrm{H}-3,31-33$ & 69.81 & $20-30$ & 3 & 25.38 & 0.20 & 17.5 & -42.1 & 4.9 \\
\hline $4 \mathrm{H}-3,50-52$ & 70.00 & $15-25$ & 3 & 38.22 & 0.13 & 46.7 & -36.9 & 2.8 \\
\hline $4 \mathrm{H}-3,60-62$ & 70.10 & $20-35$ & 4 & 19.94 & 0.12 & 26.8 & -33.6 & 7.2 \\
\hline $4 \mathrm{H}-3,73-75$ & 70.23 & $20-35$ & 4 & 29.04 & 0.08 & 26.2 & -39.1 & 5.5 \\
\hline $4 \mathrm{H}-3,97-99$ & 70.47 & $20-40$ & 4 & 29.31 & 0.18 & 41.9 & -26.3 & 6.8 \\
\hline $4 \mathrm{H}-4,43-45$ & 71.43 & $15-25$ & 3 & 37.96 & 0.06 & 53.5 & -51.7 & 4.2 \\
\hline $4 \mathrm{H}-4,60-62$ & 71.60 & $25-35$ & 3 & 18.84 & 0.11 & 28.4 & -50.5 & 2.9 \\
\hline $5 \mathrm{H}-1,67-69$ & 124.67 & $20-50$ & 5 & 184.89 & 0.02 & 84.3 & -51.0 & 4.7 \\
\hline $5 \mathrm{H}-1,80-82$ & 124.80 & $25-40$ & 4 & 128.94 & 0.05 & 85.9 & -48.1 & 1.0 \\
\hline $5 \mathrm{H}-1,91-93$ & 124.91 & $25-40$ & 3 & 251.12 & 0.04 & 92.1 & -41.7 & 0.8 \\
\hline $5 \mathrm{H}-1,102-104$ & 125.02 & $25-40$ & 4 & 140.48 & 0.03 & 87.0 & -48.1 & 1.4 \\
\hline $5 \mathrm{H}-1,110-112$ & 125.10 & $20-50$ & 4 & 232.74 & 0.02 & 98.2 & -42.2 & 4.4 \\
\hline $5 \mathrm{H}-1,128-130$ & 125.28 & $20-40$ & 4 & 283.93 & 0.03 & 90.2 & -51.8 & 3.0 \\
\hline $5 \mathrm{H}-2,130-132$ & 126.80 & $20-50$ & 5 & 379.00 & 0.02 & 0.7 & -31.4 & 2.4 \\
\hline $5 \mathrm{H}-2,142-144$ & 126.92 & $15-30$ & 4 & 516.70 & 0.02 & 6.5 & -52.6 & 2.9 \\
\hline $5 \mathrm{H}-2,146-148$ & 126.96 & $25-40$ & 4 & 355.52 & 0.01 & 358.7 & -53.4 & 3.9 \\
\hline $6 \mathrm{H}-3,71-73$ & 137.21 & $10-25$ & 4 & 44.09 & 0.07 & 345.7 & -58.2 & 6.2 \\
\hline $6 \mathrm{H}-4,56-58$ & 138.56 & $15-30$ & 4 & 79.04 & 0.17 & 321.2 & -45.6 & 2.7 \\
\hline $6 \mathrm{H}-4,80-82$ & 138.80 & $20-50$ & 5 & 68.23 & 0.07 & 327.9 & -47.9 & 2.0 \\
\hline $6 \mathrm{H}-4,74-76$ & 138.74 & $25-40$ & 4 & 102.24 & 0.10 & 324.3 & -44.7 & 1.4 \\
\hline $6 \mathrm{H}-4,86-88$ & 138.86 & $25-40$ & 4 & 188.24 & 0.08 & 327.5 & -44.3 & 2.3 \\
\hline $6 \mathrm{H}-4,103-105$ & 139.03 & $20-30$ & 3 & 74.44 & 0.07 & 335.8 & -35.8 & 4.3 \\
\hline $6 \mathrm{H}-4,107-109$ & 139.07 & $20-50$ & 5 & 159.12 & 0.04 & 318.3 & -46.7 & 2.0 \\
\hline $6 \mathrm{H}-4,128-130$ & 139.28 & $15-50$ & 6 & 78.69 & 0.17 & 334.6 & -53.2 & 0.5 \\
\hline $7 \mathrm{H}-2,10-12$ & 144.60 & $25-40$ & 4 & 630.24 & 0.02 & 61.1 & -53.0 & 2.5 \\
\hline $7 \mathrm{H}-2,14-16$ & 144.64 & $20-35$ & 4 & 475.09 & 0.03 & 54.4 & -53.2 & 2.8 \\
\hline $7 \mathrm{H}-2,22-24$ & 144.72 & $25-50$ & 4 & 600.62 & 0.03 & 37.1 & -50.8 & 1.3 \\
\hline $7 \mathrm{H}-2,56-58$ & 145.06 & $25-50$ & 4 & 460.62 & 0.03 & 40.6 & -55.9 & 1.6 \\
\hline $7 \mathrm{H}-2,64-66$ & 145.14 & $25-40$ & 4 & 133.91 & 0.14 & 26.7 & -46.5 & 0.6 \\
\hline $7 \mathrm{H}-2,90-92$ & 145.40 & $25-50$ & 4 & 357.55 & 0.05 & 37.9 & -56.3 & 0.9 \\
\hline $7 \mathrm{H}-2,108-110$ & 145.58 & $25-40$ & 4 & 316.65 & 0.04 & 71.0 & -48.7 & 0.7 \\
\hline $7 \mathrm{H}-2,134-136$ & 145.84 & $25-50$ & 4 & 894.71 & 0.03 & 52.6 & -49.6 & 2.5 \\
\hline $7 \mathrm{H}-3,18-20$ & 146.18 & $25-50$ & 4 & 632.85 & 0.02 & 25.7 & -42.6 & 1.2 \\
\hline $7 \mathrm{H}-3,20-22$ & 146.20 & $30-40$ & 3 & 354.50 & 0.04 & 11.4 & -51.4 & 2.8 \\
\hline $7 \mathrm{H}-3,30-32$ & 146.30 & $25-50$ & 4 & 450.51 & 0.02 & 21.8 & -52.4 & 3.9 \\
\hline $7 \mathrm{H}-3,95-97$ & 146.95 & $30-40$ & 3 & 184.06 & 0.05 & 36.8 & -42.5 & 3.6 \\
\hline $10 \mathrm{H}-1,54-56$ & 172.04 & $15-30$ & 4 & 46.16 & 0.09 & 352.1 & -48.9 & 4.0 \\
\hline $10 \mathrm{H}-1,62-64$ & 172.12 & $15-40$ & 5 & 43.68 & 0.10 & 353.7 & -28.8 & 5.7 \\
\hline $10 \mathrm{H}-1,63-65$ & 172.13 & 25 & 1 & 36.64 & 0.07 & 359.6 & -30.4 & 2.5 \\
\hline \multicolumn{9}{|l|}{ 135-841A- } \\
\hline $4 \mathrm{H}-1,120-122$ & 28.70 & $20-50$ & 4 & 351.02 & 0.02 & 14.5 & -50.6 & 3.2 \\
\hline $4 \mathrm{H}-2,30-32$ & 29.30 & $30-50$ & 3 & 110.55 & 0.01 & 172.2 & $41.3^{\mathrm{R}}$ & 6.2 \\
\hline $4 \mathrm{H}-2,50-52$ & 29.50 & $30-40$ & 2 & 98.77 & 0.02 & 196.8 & $22.6^{\mathrm{R}}$ & 2.9 \\
\hline $4 \mathrm{H}-2,82-84$ & 29.82 & $20-40$ & 3 & 106.39 & 0.04 & 198.7 & $27.7^{R}$ & 3.2 \\
\hline $4 \mathrm{H}-2,124-126$ & 30.24 & $20-50$ & 4 & 106.94 & 0.03 & 182.0 & $43.0^{R}$ & 5.1 \\
\hline $4 \mathrm{H}-3,30-32$ & 30.80 & $20-40$ & 3 & 96.53 & 0.05 & 193.9 & $25.1^{R}$ & 3.3 \\
\hline $4 \mathrm{H}-3,80-82$ & 31.30 & $20-40$ & 3 & 117.26 & 0.03 & 18.8 & -46.1 & 4.0 \\
\hline $4 \mathrm{H}-3,120-122$ & 31.70 & $20-40$ & 3 & 163.77 & 0.03 & 356.7 & -50.4 & 5.9 \\
\hline $4 \mathrm{H}-4,38-40$ & 32.38 & $20-40$ & 3 & 145.35 & 0.04 & 0.4 & -48.0 & 2.1 \\
\hline $4 \mathrm{H}-4,55-57$ & 32.55 & $10-25$ & 4 & 145.50 & 0.11 & 33.3 & -46.5 & 2.1 \\
\hline $4 \mathrm{H}-4,65-67$ & 32.65 & $7-20$ & 4 & 127.15 & 0.10 & 17.1 & -50.9 & 1.3 \\
\hline $4 \mathrm{H}-4,80-82$ & 32.80 & $20-50$ & 4 & 154.14 & 0.05 & 356.2 & -27.4 & 2.5 \\
\hline $4 \mathrm{H}-4,95-97$ & 32.95 & $20-40$ & 4 & 93.25 & 0.06 & 18.8 & -38.5 & 2.2 \\
\hline $4 \mathrm{H}-4,120-122$ & 33.20 & $20-40$ & 3 & 113.47 & 0.05 & 351.4 & -29.7 & 2.0 \\
\hline $4 \mathrm{H}-5,43-45$ & 33.93 & $30-50$ & 3 & 100.11 & 0.02 & 220.1 & $28.8^{\mathrm{R}}$ & 10.4 \\
\hline $4 \mathrm{H}-5,60-62$ & 34.10 & $20-50$ & 4 & 40.51 & 0.20 & 186.4 & $38.8^{\mathrm{R}}$ & 0.6 \\
\hline $4 \mathrm{H}-5,75-77$ & 34.25 & $30-50$ & 3 & 118.90 & 0.03 & 346.9 & -43.8 & 4.3 \\
\hline $4 \mathrm{H}-5,100-102$ & 34.50 & $20-50$ & 4 & 91.50 & 0.09 & 192.4 & $46.1^{R}$ & 1.9 \\
\hline $4 \mathrm{H}-6,40-42$ & 35.40 & $20-50$ & 4 & 81.57 & 0.10 & 184.9 & $35.4^{\mathrm{R}}$ & 1.5 \\
\hline $5 \mathrm{H}-1,40-42$ & 37.40 & $15-40$ & 5 & 48.80 & 0.50 & 226.3 & $38.0^{\mathrm{R}}$ & 3.1 \\
\hline $5 \mathrm{H}-1,75-77$ & 37.75 & $20-50$ & 4 & 19.55 & 0.33 & 213.3 & $32.1^{R}$ & 1.3 \\
\hline $5 \mathrm{H}-2,40-42$ & 38.45 & $20-40$ & 4 & 26.36 & 0.45 & 222.6 & $29.3^{R}$ & 1.2 \\
\hline $5 \mathrm{H}-2,80-82$ & 39.30 & $20-50$ & 4 & 25.92 & 0.30 & 212.8 & $25.2^{\mathrm{R}}$ & 1.4 \\
\hline $5 \mathrm{H}-2,120-122$ & 39.70 & $20-50$ & 4 & 51.61 & 0.31 & 219.7 & $32.3^{R}$ & 0.6 \\
\hline $5 \mathrm{H}-3,10-12$ & 40.10 & $20-50$ & 4 & 17.39 & 0.24 & 224.1 & $46.6^{R}$ & 3.0 \\
\hline
\end{tabular}


Appendix B (continued).

\begin{tabular}{|c|c|c|c|c|c|c|c|c|}
\hline $\begin{array}{l}\text { Core, section, } \\
\text { interval }(\mathrm{cm})\end{array}$ & $\begin{array}{l}\text { Depth } \\
\text { (mbsf) }\end{array}$ & $\begin{array}{c}\text { AF step } \\
(\mathrm{mT})\end{array}$ & $N$ & $\begin{array}{c}J_{0} \\
\left(\mathrm{mAm}^{-1}\right)\end{array}$ & $\begin{array}{l}J / J_{0} \\
(\%)\end{array}$ & $\begin{array}{l}\text { Dec } \\
\left({ }^{\circ} \mathrm{E}\right)\end{array}$ & $\begin{array}{l}\text { Inc } \\
\left({ }^{\circ} \mathrm{D}\right)\end{array}$ & $\begin{array}{l}\text { CSD } \\
\left({ }^{\circ}\right)\end{array}$ \\
\hline $5 \mathrm{H}-3,40-42$ & 40.40 & $15-40$ & 5 & 38.44 & 0.41 & 237.1 & $51.5^{\mathrm{R}}$ & 1.4 \\
\hline $5 \mathrm{H}-3,44-46$ & 40.44 & $20-50$ & 4 & 35.57 & 0.37 & 216.7 & $50.3^{R}$ & 1.1 \\
\hline $5 \mathrm{H}-3,83-85$ & 40.83 & $20-50$ & 4 & 50.19 & 0.47 & 226.9 & $48.8^{R}$ & 0.6 \\
\hline $5 \mathrm{H}-4,40-42$ & 41.45 & $20-40$ & 4 & 41.75 & 0.22 & 232.8 & $39.3^{R}$ & 2.0 \\
\hline $5 \mathrm{H}-4,69-71$ & 42.19 & $20-50$ & 4 & 40.04 & 0.26 & 210.9 & $39.3^{R}$ & 1.3 \\
\hline $5 \mathrm{H}-4,118-120$ & 42.68 & $20-50$ & 4 & 28.42 & 0.28 & 223.6 & $45.0^{R}$ & 1.7 \\
\hline $5 \mathrm{H}-5,85-87$ & 43.85 & $20-50$ & 4 & 30.69 & 0.17 & 217.9 & $29.4^{R}$ & 4.2 \\
\hline $5 \mathrm{H}-6,37-39$ & 44.87 & $20-50$ & 4 & 82.35 & 0.04 & 61.5 & -51.6 & 6.5 \\
\hline $5 \mathrm{H}-6,80-82$ & 45.30 & $20-50$ & 4 & 114.75 & 0.05 & 164.1 & $-69.8^{\circ}$ & 6.4 \\
\hline $5 \mathrm{H}-6,120-122$ & 45.70 & $20-50$ & 4 & 142.35 & 0.05 & 158.5 & $-54.3^{\circ}$ & 4.3 \\
\hline $6 \mathrm{H}-1,40-42$ & 46.90 & $20-50$ & 4 & 248.01 & 0.02 & 53.3 & -52.4 & 6.9 \\
\hline $6 \mathrm{H}-2,40-42$ & 48.40 & $30-60$ & 4 & 330.47 & 0.02 & 204.2 & $16.0^{R}$ & 3.4 \\
\hline $6 \mathrm{H}-3,84-86$ & 50.34 & $50-60$ & 2 & 261.41 & 0.02 & 232.0 & $22.2^{\mathrm{R}}$ & 4.7 \\
\hline $6 \mathrm{H}-4,43-45$ & 51.43 & $40-60$ & 3 & 387.32 & 0.04 & 16.4 & -61.5 & 3.3 \\
\hline $6 \mathrm{H}-4,81-83$ & 51.81 & $30-50$ & 3 & 179.49 & 0.03 & 351.8 & -54.7 & 8.9 \\
\hline $6 \mathrm{H}-4,122-124$ & 52.22 & $20-50$ & 4 & 210.86 & 0.03 & 90.9 & -66.3 & 6.4 \\
\hline $6 \mathrm{H}-5,40-42$ & 52.90 & $20-50$ & 4 & 220.29 & 0.02 & 331.3 & -57.9 & 10.3 \\
\hline $8 \mathrm{H}-1,22-24$ & 65.72 & $30-50$ & 3 & 432.91 & 0.01 & 226.0 & $-52.6^{\circ}$ & 3.7 \\
\hline $8 \mathrm{H}-1,28-30$ & 65.78 & $40-60$ & 3 & 385.00 & 0.04 & 162.9 & $62.7^{R}$ & 2.0 \\
\hline $8 \mathrm{H}-1,80-82$ & 66.30 & $30-60$ & 4 & 581.80 & 0.04 & 163.9 & $38.9^{R}$ & 2.0 \\
\hline $8 \mathrm{H}-1,142-144$ & 66.92 & $20-50$ & 4 & 433.42 & 0.06 & 226.4 & $45.8^{R}$ & 3.4 \\
\hline $8 \mathrm{H}-2,40-42$ & 67.40 & $30-60$ & 4 & 611.73 & 0.02 & 162.9 & $70.1^{R}$ & 2.2 \\
\hline $8 \mathrm{H}-2,80-82$ & 67.80 & $30-60$ & 4 & 303.02 & 0.04 & 256.3 & $43.8^{R}$ & 3.0 \\
\hline $8 \mathrm{H}-2,120-122$ & 68.20 & $40-60$ & 3 & 355.98 & 0.07 & 187.6 & $35.9^{R}$ & 1.3 \\
\hline $8 \mathrm{H}-3,40-42$ & 68.90 & $40-60$ & 3 & 110.87 & 0.07 & 182.8 & $13.2^{R}$ & 1.3 \\
\hline $8 \mathrm{H}-3,70-72$ & 69.20 & $20-50$ & 4 & 405.45 & 0.06 & 243.5 & $21.4^{\mathrm{R}}$ & 2.8 \\
\hline $8 \mathrm{H}-3,80-82$ & 69.30 & $30-60$ & 4 & 127.39 & 0.07 & 184.4 & $27.1^{R}$ & 2.2 \\
\hline $8 \mathrm{H}-4,40-42$ & 70.40 & $40-60$ & 3 & 725.16 & 0.01 & 146.0 & $-54.2^{\circ}$ & 7.4 \\
\hline
\end{tabular}

Notes: AF step = demagnetization minimum and maximum altemating-field strengths used in determining characteristic remanent magnetization $(\mathrm{ChRM}) ; J_{0}=$ natural remanent magnetization $(\mathrm{NRM})$ intensity, in $10^{-3} \mathrm{Am}^{-1} ; J / J_{0}=$ normalized magnetization intensity at maximum demagnetization used in ChRM determination; "Dec" and "Inc" = paleomagnetic declination and inclination, in sample coordinates; $\mathrm{CSD}=$ circular standard deviation of mean direction. Superscript $\mathrm{R}=$ reversed polarity sample, and asterisk $(*)=$ vector not used in mean pole calculations. $N$ as in Appendix A. 
APPENDIX C

Bedding-corrected Paleomagnetic Data, Hole 841A

\begin{tabular}{|c|c|c|c|c|c|c|}
\hline \multirow[b]{2}{*}{$\begin{array}{l}\text { Core, section, } \\
\text { interval }(\mathrm{cm})\end{array}$} & \multicolumn{3}{|c|}{ Individual layer } & \multirow[b]{2}{*}{$\begin{array}{l}\text { Inc } \\
\left({ }^{\circ} \mathrm{D}\right)\end{array}$} & \multicolumn{2}{|c|}{ Average bedding } \\
\hline & $\begin{array}{l}\text { Dip } \\
\left({ }^{\circ} \mathrm{D}\right)\end{array}$ & $\begin{array}{l}\text { Azimuth } \\
\left({ }^{\circ} \mathrm{E}\right)\end{array}$ & $\begin{array}{l}\text { Dec } \\
\left({ }^{\circ} \mathrm{E}\right)\end{array}$ & & $\begin{array}{l}\text { Dec } \\
\left({ }^{\circ} \mathrm{E}\right)\end{array}$ & $\begin{array}{l}\text { Inc } \\
\left({ }^{\circ} \mathrm{D}\right)\end{array}$ \\
\hline \multicolumn{7}{|l|}{$135-841 \mathrm{~A}-$} \\
\hline $4 \mathrm{H}-1,120-122$ & 2.0 & 269.0 & 16.8 & -50.0 & 12.2 & -61.0 \\
\hline $4 \mathrm{H}-2,30-32$ & 2.0 & 269.0 & 174.0 & 41.5 & 166.4 & 50.2 \\
\hline $4 \mathrm{H}-2,50-52$ & 2.0 & 269.0 & 197.6 & 22.0 & 196.3 & 33.1 \\
\hline $4 \mathrm{H}-2,82-84$ & 2.0 & 269.0 & 199.7 & 27.0 & 198.3 & 38.2 \\
\hline $4 \mathrm{H}-2,124-126$ & 8.0 & 19.0 & 179.3 & 50.6 & 177.6 & 52.7 \\
\hline $4 \mathrm{H}-3,30-32$ & 8.0 & 12.0 & 194.1 & 33.1 & 193.0 & 35.5 \\
\hline $4 \mathrm{H}-3,80-82$ & 8.0 & 12.0 & 20.0 & -54.0 & 18.0 & -56.6 \\
\hline $4 \mathrm{H}-3,120-122$ & 8.8 & 12.0 & 353.0 & -58.8 & 349.5 & -59.6 \\
\hline $4 \mathrm{H}-4,38-40$ & 13.0 & 22.0 & 352.7 & -59.8 & 354.7 & -57.6 \\
\hline $4 \mathrm{H}-4,55-57$ & 13.0 & 22.0 & 37.3 & -59.2 & 36.3 & -56.7 \\
\hline $4 \mathrm{H}-4,65-67$ & 13.0 & 22.0 & 15.0 & -63.8 & 15.6 & -61.4 \\
\hline $4 \mathrm{H}-4,80-82$ & 13.0 & 22.0 & 352.2 & -38.9 & 353.2 & -36.8 \\
\hline $4 \mathrm{H}-4,95-97$ & 13.0 & 22.0 & 18.0 & -51.5 & 18.2 & -49.0 \\
\hline $4 \mathrm{H}-4,120-122$ & 13.0 & 26.0 & 345.9 & -40.1 & 347.6 & -38.6 \\
\hline $4 \mathrm{H}-5,43-45$ & 6.0 & 26.0 & 221.0 & 34.6 & 222.4 & 38.7 \\
\hline $4 \mathrm{H}-5,60-62$ & 2.0 & 224.0 & 187.3 & 37.2 & 183.5 & 48.9 \\
\hline $4 \mathrm{H}-5,75-77$ & 2.0 & 224.0 & 348.5 & -42.7 & 339.6 & -52.0 \\
\hline $4 \mathrm{H}-5,100-102$ & 2.0 & 224.0 & 193.4 & 44.4 & 190.0 & 56.4 \\
\hline $4 \mathrm{H}-6,40-42$ & 15.0 & 26.0 & 179.3 & 49.1 & 182.1 & 45.4 \\
\hline $5 \mathrm{H}-1,40-42$ & 15.0 & 26.0 & 232.2 & 51.8 & 215.6 & 36.9 \\
\hline $5 \mathrm{H}-1,75-77$ & 15.0 & 26.0 & 215.1 & 47.0 & 205.5 & 28.3 \\
\hline $5 \mathrm{H}-2,40-42$ & 10.0 & 4.0 & 226.9 & 36.9 & 215.1 & 27.7 \\
\hline $5 \mathrm{H}-2,80-82$ & 10.0 & 4.0 & 215.7 & 33.8 & 207.0 & 21.5 \\
\hline $5 \mathrm{H}-2,120-122$ & 10.0 & 137.0 & 213.7 & 30.5 & 211.4 & 29.9 \\
\hline $5 \mathrm{H}-3,10-12$ & 13.0 & 148.0 & 212.1 & 42.1 & 210.0 & 44.6 \\
\hline $5 \mathrm{H}-3,40-42$ & 13.0 & 148.0 & 221.4 & 49.5 & 219.3 & 52.2 \\
\hline $5 \mathrm{H}-3,44-46$ & 13.0 & 148.0 & 204.1 & 44.2 & 201.6 & 46.4 \\
\hline $5 \mathrm{H}-3,83-85$ & 11.0 & 216.0 & 225.1 & 38.0 & 211.4 & 47.3 \\
\hline $5 \mathrm{H}-4,40-42$ & 9.0 & 280.0 & 237.4 & 32.9 & 221.3 & 39.7 \\
\hline $5 \mathrm{H}-4,69-71$ & 9.0 & 280.0 & 217.2 & 35.6 & 201.0 & 34.7 \\
\hline $5 \mathrm{H}-4,118-120$ & 10.0 & 83.0 & 215.8 & 52.3 & 210.2 & 43.0 \\
\hline $5 \mathrm{H}-5,85-87$ & 20.0 & 105.0 & 205.6 & 35.3 & 210.6 & 26.7 \\
\hline $5 \mathrm{H}-6,37-39$ & 20.0 & 105.0 & 25.0 & -62.9 & 43.4 & -53.4 \\
\hline $5 \mathrm{H}-6,80-82$ & 20.0 & 105.0 & 222.5 & -70.5 & 203.0 & -79.6 \\
\hline $5 \mathrm{H}-6,120-122$ & 20.0 & 105.0 & 189.1 & -61.9 & 170.5 & -66.5 \\
\hline $6 \mathrm{H}-1,40-42$ & 20.0 & 105.0 & 25.0 & -60.9 & 24.2 & -75.2 \\
\hline $6 \mathrm{H}-2,40-42$ & 26.0 & 105.0 & 196.0 & 18.4 & 194.9 & 32.4 \\
\hline $6 \mathrm{H}-3,84-86$ & 21.0 & 121.0 & 222.4 & 28.1 & 225.1 & 46.3 \\
\hline $6 \mathrm{H}-4,43-45$ & 21.0 & 121.0 & 348.2 & -51.0 & 321.7 & -65.5 \\
\hline $6 \mathrm{H}-4,81-83$ & 21.0 & 121.0 & 336.3 & -39.1 & 316.4 & -51.3 \\
\hline $6 \mathrm{H}-4,122-124$ & 21.0 & 121.0 & 30.0 & -78.4 & 185.4 & -81.4 \\
\hline $6 \mathrm{H}-5,40-42$ & 21.0 & 121.0 & 321.1 & -38.8 & 300.3 & -46.2 \\
\hline $6 \mathrm{H}-1,22-24$ & 10.0 & 248.0 & 219.4 & -61.7 & 229.7 & -46.7 \\
\hline $6 \mathrm{H}-1,28-30$ & 10.0 & 248.0 & 180.9 & 60.3 & 150.3 & 61.6 \\
\hline $6 \mathrm{H}-1,80-82$ & 10.0 & 248.0 & 171.6 & 37.2 & 158.6 & 38.4 \\
\hline $6 \mathrm{H}-1,142-144$ & 4.0 & 258.0 & 228.4 & 42.4 & 222.4 & 51.5 \\
\hline $8 \mathrm{H}-2,40-42$ & 4.0 & 258.0 & 174.0 & 70.1 & 145.4 & 68.7 \\
\hline $8 \mathrm{H}-2,80-82$ & 4.0 & 258.0 & 256.4 & 39.8 & 256.4 & 50.5 \\
\hline $8 \mathrm{H}-2,120-122$ & 4.0 & 258.0 & 190.2 & 34.5 & 182.8 & 38.1 \\
\hline $8 \mathrm{H}-3,40-42$ & 3.0 & 359.0 & 182.9 & 16.2 & 181.2 & 15.1 \\
\hline $8 \mathrm{H}-3,70-72$ & 3.0 & 62.0 & 243.5 & 24.4 & 242.8 & 27.9 \\
\hline $8 \mathrm{H}-3,80-82$ & 3.0 & 62.0 & 183.0 & 28.7 & 181.0 & 29.0 \\
\hline $8 \mathrm{H}-4,40-42$ & 8.0 & 157.0 & 143.2 & -62.0 & 155.3 & -56.0 \\
\hline
\end{tabular}

Notes: Individual layer $=$ corrections made for individual layers; "Dip" and "Azimuth" = dip magnitude and dip direction; "Dec" and "Inc" = corrected paleomagnetic declination and inclination; "Dec" and "Inc" for average bedding, = paleomagnetic declination and inclination corrected using average value for core-dip and dip direction. 
APPENDIX D

Paleomagnetic Data, Hole 841B

\begin{tabular}{|c|c|c|c|c|c|c|c|c|}
\hline $\begin{array}{l}\text { Core, section, } \\
\text { interval }(\mathrm{cm})\end{array}$ & $\begin{array}{l}\text { Depth } \\
\text { (mbsf) }\end{array}$ & $\begin{array}{c}\text { AF step } \\
(\mathrm{mT})\end{array}$ & $\mathrm{N}$ & $\begin{array}{c}J_{0} \\
\left(\mathrm{mAm}^{-1}\right)\end{array}$ & $\begin{array}{l}J / J_{0} \\
(\%)\end{array}$ & $\begin{array}{l}\text { Dec } \\
\left({ }^{\circ} \mathrm{E}\right)\end{array}$ & $\begin{array}{l}\text { Inc } \\
\left({ }^{\circ} \mathrm{D}\right)\end{array}$ & $\begin{array}{c}\text { CSD } \\
\left({ }^{\circ}\right)\end{array}$ \\
\hline \multicolumn{9}{|l|}{ 135-841B- } \\
\hline $2 \mathrm{R}-1,116-118$ & 170.96 & $15-40$ & 5 & 223.64 & 0.31 & 30.0 & -41.8 & 0.8 \\
\hline $2 R-2,63-65$ & 171.93 & $15-40$ & 5 & 222.76 & 0.42 & 355.0 & -47.1 & 0.4 \\
\hline $2 \mathrm{R}-2,101-103$ & 172.31 & $15-40$ & 5 & 317.58 & 0.35 & 153.3 & -49.2 & 0.7 \\
\hline $2 \mathrm{R}-2,126-128$ & 172.56 & $15-40$ & 5 & 710.10 & 0.43 & 161.1 & -37.1 & 0.1 \\
\hline $3 \mathrm{R}-1,16-18$ & 179.56 & $15-40$ & 5 & 569.79 & 0.43 & 7.0 & -30.5 & 0.3 \\
\hline $3 R-1,24-26$ & 179.64 & $15-40$ & 5 & 464.50 & 0.40 & 108.9 & -35.7 & 0.4 \\
\hline $3 R-2,42-44$ & 180.95 & $15-40$ & 5 & 654.96 & 0.37 & 222.4 & -31.2 & 0.1 \\
\hline $3 R-2,54-56$ & 181.07 & $15-40$ & 5 & 797.83 & 0.43 & 227.4 & -35.8 & 0.3 \\
\hline $4 \mathrm{R}-1.67-69$ & 189.77 & $15-40$ & 5 & 292.68 & 0.35 & 247.5 & -42.0 & 0.4 \\
\hline $4 \mathrm{R}-2,49-51$ & 191.09 & $15-40$ & 5 & 118.82 & 0.40 & 108.0 & -45.1 & 0.7 \\
\hline $4 \mathrm{R}-2,55-57$ & 191.15 & $30-60$ & 4 & 123.03 & 0.14 & 310.3 & -45.7 & 3.6 \\
\hline $5 R-1,15-17$ & 198.85 & $15-40$ & 5 & 311.64 & 0.32 & 66.9 & -26.6 & 0.7 \\
\hline $5 R-1,37-39$ & 199.07 & $15-40$ & 5 & 526.94 & 0.33 & 179.5 & -40.5 & 0.5 \\
\hline $6 \mathrm{R}-1,71-73$ & 209.11 & $15-50$ & 5 & 1205.78 & 0.35 & 73.2 & -39.6 & 0.6 \\
\hline $7 \mathrm{R}-1,23-25$ & 218.33 & $15-40$ & 5 & 720.44 & 0.57 & 77.0 & -22.6 & 0.4 \\
\hline $7 R-2,12-14$ & 219.72 & $15-30$ & 4 & 333.79 & 0.56 & 302.1 & -34.4 & 0.2 \\
\hline $9 R-1,59-61$ & 237.99 & $15-40$ & 5 & 153.92 & 0.35 & 237.0 & -58.7 & 1.2 \\
\hline $9 R-1,65-67$ & 238.05 & $15-40$ & 5 & 117.75 & 0.36 & 141.9 & -62.5 & 1.1 \\
\hline $9 \mathrm{R}-2,91-93$ & 239.81 & $20-50$ & 4 & 104.25 & 0.28 & 350.7 & $57.8^{R}$ & 2.1 \\
\hline 9R-2, 99-101 & 239.89 & $20-40$ & 3 & 116.96 & 0.44 & 256.7 & -66.9 & 1.1 \\
\hline $12 R-2,104-106$ & 268.84 & $15-40$ & 5 & 180.93 & 0.30 & 99.9 & -55.3 & 0.8 \\
\hline $12 \mathrm{R}-2,114-116$ & 268.94 & $15-40$ & 5 & 381.89 & 0.47 & 103.6 & -56.6 & 0.3 \\
\hline $13 R-4,3-5$ & 280.13 & $15-40$ & 5 & 178.32 & 0.37 & 315.6 & -57.2 & 1.3 \\
\hline $13 R-4,55-57$ & 280.65 & $15-40$ & 5 & 188.97 & 0.32 & 316.3 & -41.8 & 0.6 \\
\hline $15 \mathrm{R}-1,73-75$ & 295.63 & $30-50$ & 3 & 282.59 & 0.05 & 279.1 & -10.9 & 2.9 \\
\hline $15 \mathrm{R}-1,104-106$ & 295.94 & $20-40$ & 5 & 88.33 & 0.25 & 122.2 & $57.4^{\mathrm{R}}$ & 3.1 \\
\hline $15 \mathrm{R}-1,113-115$ & 296.03 & $20-50$ & 4 & 181.48 & 0.09 & 160.9 & $44.4^{R}$ & 3.3 \\
\hline $15 R-2,42-44$ & 296.82 & $15-40$ & 5 & 107.83 & 0.22 & 110.2 & -48.9 & 2.4 \\
\hline $16 \mathrm{R}-1,78-80$ & 305.38 & $15-40$ & 5 & 62.14 & 0.16 & 153.5 & -45.7 & 3.8 \\
\hline $16 \mathrm{R}-1,95-97$ & 305.55 & $20-40$ & 3 & 90.96 & 0.10 & 355.0 & $45.5^{\mathrm{R}}$ & 2.9 \\
\hline $16 \mathrm{R}-1,98-100$ & 305.58 & $15-40$ & 4 & 22.76 & 0.41 & 352.9 & $39.8^{R}$ & 5.9 \\
\hline $16 \mathrm{R}-2,124-126$ & 307.34 & $15-40$ & 5 & 59.63 & 0.22 & 207.7 & $31.9^{R}$ & 4.5 \\
\hline $16 \mathrm{R}-2,138-140$ & 307.48 & $10-25$ & 4 & 63.90 & 0.27 & 300.7 & -25.1 & 2.1 \\
\hline $16 \mathrm{R}-3,29-31$ & 307.89 & $15-25$ & 3 & 48.32 & 0.74 & 45.5 & $42.5^{*}$ & 1.5 \\
\hline $16 \mathrm{R}-3,53-55$ & 308.13 & $15-25$ & 3 & 67.41 & 0.45 & 42.1 & $31.0^{*}$ & 1.8 \\
\hline $16 \mathrm{R}-5,37-39$ & 310.97 & $15-25$ & 3 & 84.64 & 0.32 & 352.8 & -42.0 & 2.7 \\
\hline $16 R-5,61-63$ & 311.21 & $15-50$ & 6 & 59.04 & 0.12 & 333.5 & -15.8 & 3.8 \\
\hline $16 \mathrm{R}-5,84-86$ & 311.44 & $15-40$ & 5 & 71.56 & 0.21 & 234.5 & $24.1^{R}$ & 3.0 \\
\hline $16 \mathrm{R}-5,92-94$ & 311.52 & $15-40$ & 5 & 72.92 & 0.27 & 92.9 & -23.4 & 2.1 \\
\hline $17 \mathrm{R}-2,19-21$ & 315.49 & $15-30$ & 5 & 55.94 & 0.48 & 181.4 & $34.3^{\mathrm{R}}$ & 1.3 \\
\hline $17 \mathrm{R}-2,43-45$ & 315.73 & $40-60$ & 3 & 62.93 & 0.12 & 186.1 & $21.5^{\mathrm{R}}$ & 4.1 \\
\hline $17 \mathrm{R}-2,68-70$ & 315.98 & $20-30$ & 3 & 24.27 & 0.82 & 288.8 & $38.9^{R}$ & 3.0 \\
\hline $17 \mathrm{R}-2,83-85$ & 316.13 & $15-50$ & 6 & 37.04 & 0.17 & 236.4 & $51.5^{\mathrm{R}}$ & 3.5 \\
\hline $17 \mathrm{R}-3,135-137$ & 318.15 & $15-30$ & 4 & 97.59 & 0.73 & 180.1 & $34.8^{R}$ & 0.6 \\
\hline $17 \mathrm{R}-4,49-51$ & 318.79 & $15-40$ & 4 & 75.47 & 0.42 & 224.3 & $35.0^{\mathrm{R}}$ & 2.7 \\
\hline $18 \mathrm{R}-1,105-107$ & 324.55 & $15-40$ & 5 & 145.51 & 0.32 & 289.2 & $44.2^{\mathrm{R}}$ & 0.8 \\
\hline $18 \mathrm{R}-2,126-128$ & 326.26 & $15-40$ & 5 & 473.91 & 0.46 & 212.5 & $39.1^{R}$ & 0.9 \\
\hline $19 \mathrm{R}-1,2-4$ & 333.22 & $15-40$ & 5 & 96.59 & 0.35 & 236.4 & $30.5^{R}$ & 1.9 \\
\hline 20R-2, $12-14$ & 344.10 & $15-40$ & 5 & 68.35 & 0.42 & 60.0 & $40.3^{\mathrm{R}}$ & 1.1 \\
\hline $22 \mathrm{R}-3,47-49$ & 364.87 & $15-30$ & 4 & 137.30 & 0.37 & 201.7 & $21.5^{R}$ & 1.8 \\
\hline $22 \mathrm{R}-3,68-70$ & 365.08 & $15-30$ & 4 & 134.05 & 0.43 & 200.3 & $42.0^{R}$ & 1.4 \\
\hline $24 \mathrm{R}-1,96-98$ & 381.66 & $15-40$ & 5 & 589.55 & 0.31 & 48.1 & $47.3^{R}$ & 1.2 \\
\hline $29 \mathrm{R}-2,26-28$ & 430.86 & $15-50$ & 6 & 290.98 & 0.13 & 17.1 & -48.7 & 1.1 \\
\hline $32 \mathrm{R}-1,102-104$ & 459.12 & $15-50$ & 6 & 185.77 & 0.23 & 168.9 & -45.1 & 1.3 \\
\hline $32 \mathrm{R}-1,128-130$ & 459.38 & $15-50$ & 6 & 307.30 & 0.32 & 0.5 & -38.9 & 0.8 \\
\hline $32 \mathrm{R}-1,136-138$ & 459.46 & $15-60$ & 6 & 165.11 & 0.14 & 337.9 & -50.5 & 1.7 \\
\hline $32 \mathrm{R}-2,7-9$ & 459.61 & $15-50$ & 6 & 330.99 & 0.34 & 15.0 & -44.7 & 0.8 \\
\hline $33 \mathrm{R}-1,11-13$ & 467.91 & $15-50$ & 6 & 42.05 & 0.23 & 43.2 & -44.1 & 0.9 \\
\hline $33 \mathrm{R}-1,74-76$ & 468.54 & $15-50$ & 6 & 44.35 & 0.26 & 323.3 & -41.6 & 0.5 \\
\hline $33 \mathrm{R}-1,136-138$ & 469.16 & $15-50$ & 6 & 30.67 & 0.22 & 182.6 & -37.9 & 0.9 \\
\hline $33 \mathrm{R}-2,70-72$ & 469.98 & $15-50$ & 6 & 23.30 & 0.27 & 207.3 & -37.3 & 0.7 \\
\hline $34 \mathrm{R}-2,3-5$ & 479.01 & $15-50$ & 6 & 74.85 & 0.22 & 240.2 & -84.5 & 1.1 \\
\hline $34 \mathrm{R}-2,15-17$ & 479.13 & $15-50$ & 6 & 61.48 & 0.23 & 194.9 & -77.9 & 1.3 \\
\hline $35 \mathrm{R}-1,107-109$ & 488.17 & $15-40$ & 5 & 123.11 & 0.23 & 217.9 & -31.1 & 2.7 \\
\hline $35 \mathrm{R}-2,114-116$ & 489.76 & $15-50$ & 6 & 46.80 & 0.27 & 172.1 & -28.9 & 0.7 \\
\hline $35 \mathrm{R}-3,124-126$ & 491.38 & $15-40$ & 5 & 4.10 & 0.19 & 50.3 & -29.9 & 8.7 \\
\hline $36 \mathrm{R}-1,56-58$ & 497.36 & $15-50$ & 6 & 23.11 & 0.24 & 0.1 & -14.8 & 1.0 \\
\hline $36 \mathrm{R}-3,66-68$ & 500.46 & $15-50$ & 6 & 323.51 & 0.33 & 268.0 & -47.0 & 1.0 \\
\hline $37 \mathrm{R}-1,76-78$ & 507.16 & $15-40$ & 6 & 28.59 & 0.23 & 140.0 & -34.2 & 2.7 \\
\hline $37 R-2,6-8$ & 507.96 & $20-50$ & 4 & 572.36 & 0.41 & 155.3 & -49.7 & 3.8 \\
\hline $37 \mathrm{R}-2,33-35$ & 508.23 & $20-40$ & 3 & 32.35 & 0.31 & 49.8 & $42.4^{*}$ & 2.5 \\
\hline $37 \mathrm{R}-2,35-37$ & 508.25 & $20-40$ & 3 & 70.95 & 0.43 & 47.9 & $44.0^{*}$ & 0.5 \\
\hline $37 \mathrm{R}-2,106-108$ & 508.96 & $20-50$ & 4 & 112.31 & 0.27 & 218.7 & -33.6 & 1.8 \\
\hline $37 R-2,113-115$ & 509.03 & $30-50$ & 3 & 48.35 & 0.32 & 327.4 & $35.3^{*}$ & 2.6 \\
\hline $37 R-3,48-50$ & 509.88 & $20-50$ & 4 & 64.10 & 0.25 & 199.7 & -42.2 & 1.0 \\
\hline $37 \mathrm{R}-3,111-113$ & 510.51 & $20-50$ & 4 & 118.07 & 0.22 & 189.8 & -45.8 & 0.7 \\
\hline $37 \mathrm{R}-3,114-116$ & 510.54 & $20-50$ & 4 & 102.94 & 0.27 & 198.0 & -46.0 & 0.8 \\
\hline $37 \mathrm{R}-3,119-121$ & 510.59 & $15-50$ & 6 & 179.20 & 0.20 & 162.5 & -45.4 & 1.2 \\
\hline $37 \mathrm{R}-3,133-135$ & 510.73 & $20-50$ & 4 & 96.58 & 0.28 & 189.6 & -52.0 & 1.3 \\
\hline $37 R-4,14-16$ & 511.04 & $20-50$ & 4 & 135.99 & 0.24 & 178.2 & -50.9 & 1.2 \\
\hline $37 R-4,33-35$ & 511.23 & $20-50$ & 4 & 178.78 & 0.33 & 181.1 & -42.4 & 1.2 \\
\hline $37 R-4,55-57$ & 511.45 & $20-50$ & 4 & 159.02 & 0.23 & 206.5 & -40.4 & 1.3 \\
\hline $37 \mathrm{R}-4,89-91$ & 511.79 & $15-50$ & 6 & 262.20 & 0.40 & 171.6 & -55.4 & 0.4 \\
\hline $38 \mathrm{R}-1,27-29$ & 516.37 & $20-50$ & 4 & 244.24 & 0.34 & 10.7 & -19.8 & 0.5 \\
\hline
\end{tabular}


Appendix D (continued).

\begin{tabular}{|c|c|c|c|c|c|c|c|c|}
\hline $\begin{array}{l}\text { Core, section, } \\
\text { interval }(\mathrm{cm})\end{array}$ & $\begin{array}{l}\text { Depth } \\
\text { (mbsf) }\end{array}$ & $\begin{array}{l}\text { AF step } \\
\text { (mT) }\end{array}$ & $\mathrm{N}$ & $\begin{array}{c}J_{0} \\
\left(\mathrm{mAm}^{-1}\right)\end{array}$ & $\begin{array}{l}J / J_{0} \\
(\%)\end{array}$ & $\begin{array}{l}\text { Dec } \\
\left({ }^{\circ} \mathrm{E}\right)\end{array}$ & $\begin{array}{l}\text { Inc } \\
\left({ }^{\circ} \mathrm{D}\right)\end{array}$ & $\begin{array}{l}\text { CSD } \\
\left({ }^{\circ}\right)\end{array}$ \\
\hline $38 \mathrm{R}-1,45-47$ & 516.55 & $20-40$ & 4 & 225.58 & 0.47 & 5.4 & -18.4 & 0.9 \\
\hline $38 \mathrm{R}-1,57-59$ & 516.67 & $15-50$ & 6 & 101.87 & 0.34 & 12.3 & -22.0 & 0.5 \\
\hline $38 \mathrm{R}-2,23-25$ & 517.83 & $20-50$ & 4 & 135.87 & 0.31 & 309.6 & -40.0 & 2.5 \\
\hline $38 \mathrm{R}-2,103-105$ & 518.63 & $20-50$ & 4 & 199.17 & 0.37 & 11.5 & -42.9 & 0.9 \\
\hline $38 \mathrm{R}-2,121-123$ & 518.81 & $20-50$ & 4 & 47.98 & 0.32 & 10.5 & -41.2 & 0.7 \\
\hline $38 \mathrm{R}-2,129-131$ & 518.89 & $20-50$ & 4 & 35.00 & 0.32 & 202.0 & -35.1 & 0.4 \\
\hline $38 \mathrm{R}-2,134-136$ & 518.94 & $20-50$ & 4 & 34.63 & 0.35 & 9.7 & -40.9 & 0.5 \\
\hline $38 \mathrm{R}-2,145-147$ & 519.05 & $15-50$ & 6 & 43.28 & 0.24 & 358.1 & -48.8 & 2.3 \\
\hline $38 \mathrm{R}-3,8-10$ & 519.18 & $15-50$ & 6 & 282.42 & 0.25 & 337.7 & -36.7 & 0.6 \\
\hline $38 \mathrm{R}-3,34-36$ & 519.44 & $20-50$ & 4 & 147.12 & 0.29 & 332.0 & -41.8 & 1.0 \\
\hline $38 \mathrm{R}-4,21-23$ & 520.81 & $15-50$ & 6 & 193.07 & 0.27 & 1.4 & -54.9 & 0.5 \\
\hline $39 \mathrm{R}-1,24-26$ & 525.94 & $20-40$ & 3 & 32.84 & 0.46 & 190.0 & -48.1 & 1.9 \\
\hline $39 \mathrm{R}-1,55-57$ & 526.25 & $20-50$ & 4 & 141.50 & 0.34 & 168.3 & -43.9 & 0.7 \\
\hline $39 \mathrm{R}-1,71-73$ & 526.41 & $20-50$ & 4 & 94.38 & 0.34 & 198.0 & -38.9 & 0.4 \\
\hline $39 \mathrm{R}-1,118-120$ & 526.88 & $15-50$ & 6 & 108.00 & 0.22 & 194.7 & -42.7 & 0.8 \\
\hline $39 \mathrm{R}-2,128-130$ & 528.48 & $20-50$ & 4 & 93.96 & 0.25 & 197.7 & -53.1 & 1.3 \\
\hline $39 \mathrm{R}-2,137-139$ & 528.57 & $20-50$ & 4 & 84.20 & 0.28 & 221.3 & -49.4 & 0.6 \\
\hline $40 \mathrm{R}-1,50-52$ & 535.80 & $15-50$ & 6 & 302.61 & 0.26 & 171.6 & -20.8 & 0.5 \\
\hline $40 \mathrm{R}-1,86-88$ & 536.16 & $30-50$ & 3 & 188.11 & 0.06 & 167.6 & -46.0 & 5.7 \\
\hline 40R-1,97-99 & 536.27 & $20-40$ & 3 & 173.57 & 0.03 & 310.5 & -40.5 & 8.7 \\
\hline $40 \mathrm{R}-1,120-122$ & 536.50 & $15-40$ & 5 & 56.89 & 0.14 & 187.9 & -57.9 & 4.1 \\
\hline $40 \mathrm{R}-2,49-51$ & 537.22 & $15-40$ & 5 & 110.90 & 0.20 & 189.9 & -39.8 & 2.5 \\
\hline $40 \mathrm{R}-3,11-13$ & 538.34 & $15-25$ & 7 & 246.30 & 0.63 & 196.3 & -34.7 & 0.4 \\
\hline $40 \mathrm{R}-3,113-115$ & 539.43 & $10-40$ & 4 & 84.25 & 0.09 & 181.9 & -32.3 & 6.3 \\
\hline $40 \mathrm{R}-3,131-133$ & 539.64 & $10-30$ & 3 & 26.61 & 0.16 & 257.1 & -21.7 & 8.1 \\
\hline $40 \mathrm{R}-4,31-33$ & 540.11 & $20-50$ & 4 & 34.56 & 0.05 & 186.4 & -42.5 & 11.8 \\
\hline $40 \mathrm{R}-4,56-58$ & 540.29 & $10-30$ & 5 & 44.90 & 0.27 & 234.2 & -58.3 & 2.7 \\
\hline $41 R-1,40-42$ & 545.40 & $15-25$ & 3 & 196.14 & 0.14 & 219.7 & -54.8 & 2.1 \\
\hline $41 \mathrm{R}-2,29-31$ & 546.79 & $10-25$ & 4 & 154.36 & 0.09 & 332.1 & -56.4 & 3.6 \\
\hline $41 \mathrm{R}-3,24-26$ & 548.24 & $10-25$ & 4 & 260.21 & 0.15 & 202.6 & -57.2 & 1.7 \\
\hline $42 \mathrm{R}-4,125-127$ & 560.05 & $50-0$ & 4 & 55.58 & 0.08 & 311.7 & -41.8 & 3.6 \\
\hline $43 \mathrm{R}-1,45-47$ & 564.45 & $10-25$ & 4 & 45.86 & 0.30 & 59.6 & -56.9 & 3.4 \\
\hline $43 \mathrm{R}-1,130-132$ & 565.30 & $15-40$ & 5 & 15.57 & 0.98 & 352.6 & $28.1^{\circ}$ & 3.2 \\
\hline $44 R-2,16-18$ & 575.22 & $10-25$ & 4 & 147.52 & 0.21 & 0.6 & -65.7 & 3.4 \\
\hline $44 \mathrm{R}-2,9-11$ & 594.49 & $15-40$ & 5 & 74.42 & 0.07 & 32.4 & -38.0 & 2.3 \\
\hline
\end{tabular}

Notes: $\mathrm{AF}$ step = demagnetization minimum and maximum alternating field strengths used in determining characteristic remanent magnetization $(\mathrm{ChRM}) ; J_{0}=$ natural remanent magnetization (NRM) intensity, in $10^{-3} \mathrm{Am}^{-1} ; J / J_{0}=$ normalized magnetization intensity at maximum demagnetization used in ChRM determination: "Dec" and "Inc" = paleomagnetic declination and inclination, in sample coordinates; $C S D=$ circular standard deviation of mean direction. Superscript $\mathrm{R}$ $=$ polarity sample, and asterisk $\left({ }^{*}\right)=$ sample inverted in handling. $N$ as in Appendix A. 
APPENDIX E

Reoriented Virtual Geomagnetic Pole Data, Hole 841B

\begin{tabular}{|c|c|c|c|c|c|c|c|c|c|c|c|c|c|}
\hline & & Iding & & & & & & $\mathrm{PA}$ & & & & GP B & \\
\hline $\begin{array}{l}\text { Core, section, } \\
\text { interval }(\mathrm{cm})\end{array}$ & $\begin{array}{l}\text { Dip } \\
\left({ }^{\circ} \mathrm{D}\right)\end{array}$ & Azimuth & $\begin{array}{l}\text { Sample } \\
\text { azimuth } \\
\left({ }^{\circ} \mathrm{E}\right)\end{array}$ & $\begin{array}{c}\text { FMS } \\
\text { azimuth } \\
\left({ }^{\circ} \mathrm{E}\right)\end{array}$ & $\begin{array}{c}\text { Orientation } \\
\text { type }\end{array}$ & $\begin{array}{l}\text { Dec } \\
\left({ }^{\circ} \mathrm{E}\right)\end{array}$ & $\begin{array}{l}\text { Inc } \\
\left({ }^{\circ} \mathrm{D}\right)\end{array}$ & $\begin{array}{l}\text { Latitude } \\
\left({ }^{\circ} \mathrm{N}\right)\end{array}$ & $\begin{array}{c}\text { Longitude } \\
\left({ }^{\circ} \mathrm{E}\right)\end{array}$ & $\begin{array}{l}\text { Dec } \\
\left({ }^{\circ} \mathrm{E}\right)\end{array}$ & $\begin{array}{l}\text { Inc } \\
\left({ }^{\circ} \mathrm{D}\right)\end{array}$ & $\begin{array}{l}\text { Latitude } \\
\left({ }^{\circ} \mathrm{N}\right)\end{array}$ & $\begin{array}{c}\text { Longitude } \\
\left({ }^{\circ} \mathrm{E}\right)\end{array}$ \\
\hline $135-841 \mathrm{~B}-$ & & & & & & & & . & & & & & \\
\hline $2 \mathrm{R}-1,116-118$ & 7.0 & 105.0 & 78.0 & 66.0 & $\mathrm{~F} / \mathrm{M}$ & 18.0 & -41.8 & -73.5 & 100.8 & 11.7 & -41.8 & -79.3 & 101.0 \\
\hline $2 \mathrm{R}-2,63-65$ & 11.0 & 107.0 & 150.0 & 189.0 & $\mathrm{~F} / \mathrm{M}$ & 34.0 & -47.1 & -59.1 & 111.2 & 21.9 & -49.2 & -69.4 & 118.4 \\
\hline $2 \mathrm{R}-2,101-103$ & 3.0 & 105.0 & 128.0 & 352.0 & $\mathrm{~F} / \mathrm{M}$ & 17.3 & -49.2 & -73.2 & 122.0 & 13.8 & -49.2 & 76.0 & 126.3 \\
\hline $2 \mathrm{R}-2,126-128$ & 4.0 & 154.0 & 339.0 & 189.0 & $\mathrm{~F} / \mathrm{M}$ & 11.1 & -37.1 & -79.4 & 82.5 & 9.4 & -33.9 & -80.0 & 67.9 \\
\hline $3 \mathrm{R}-1,16-18$ & 9.0 & 214.0 & 176.0 & 173.0 & $\mathrm{~F} / \mathrm{M}$ & 4.0 & -30.5 & -82.1 & 33.9 & 6.2 & -22.6 & -77.0 & 32.7 \\
\hline $3 R-1,24-26$ & 14.0 & 123.0 & 123.0 & 101.0 & $\mathrm{~F} / \mathrm{M}$ & 86.9 & -35.7 & -10.5 & 111.9 & 83.4 & -49.2 & -16.9 & 120.8 \\
\hline $3 R-2,42-44$ & 10.0 & 302.0 & 302.0 & 95.0 & $\mathrm{~B} / \mathrm{M}$ & 15.4 & -31.2 & -74.2 & 73.3 & 9.2 & -32.5 & -79.7 & 63.0 \\
\hline $3 \mathrm{R}-2,54-56$ & 12.0 & 301.0 & 301.0 & 95.0 & $\mathrm{~B} / \mathrm{M}$ & 21.4 & -35.8 & -69.8 & 88.8 & 12.5 & -38.3 & -78.3 & 88.3 \\
\hline $4 \mathrm{R}-1,67-69$ & 11.0 & 96.0 & 326.0 & 77.0 & $\mathrm{~F} / \mathrm{M}$ & 358.5 & -42.0 & -88.4 & 241.5 & 349.2 & -39.7 & -80.0 & 277.2 \\
\hline $4 \mathrm{R}-2,49-51$ & 4.0 & 323.0 & 17.0 & 5.0 & $\mathrm{~F} / \mathrm{M}$ & 96.0 & -45.1 & -5.3 & 121.5 & 98.7 & -42.3 & -2.2 & 120.5 \\
\hline $4 \mathrm{R}-2,55-57$ & 9.0 & 179.0 & 154.0 & 5.0 & $\mathrm{~F} / \mathrm{M}$ & 161.3 & -45.7 & 36.4 & 163.9 & 157.7 & -54.2 & 28.2 & 164.0 \\
\hline $5 \mathrm{R}-1,15-17$ & 5.0 & 90.0 & 90.0 & 83.0 & $\mathrm{~B} / \mathrm{M}$ & 59.9 & -26.6 & -32.9 & 96.8 & 58.8 & -31.2 & -34.8 & 112.9 \\
\hline $5 \mathrm{R}-1,37-39$ & 8.0 & 203.0 & 203.0 & 78.0 & $\mathrm{~B} / \mathrm{M}$ & 54.5 & -40.5 & -40.2 & 106.0 & 51.2 & -47.7 & -44.0 & 112.9 \\
\hline $6 \mathrm{R}-1,52-54$ & 21.0 & 27.0 & 334.0 & 58.0 & $\mathrm{~F} / \mathrm{M}$ & 87.9 & -32.3 & -8.7 & 110.1 & 102.4 & -40.3 & 1.5 & 120.6 \\
\hline $6 \mathrm{R}-1,71-73$ & 4.0 & 48.0 & 169.0 & 113.0 & $\mathrm{~F} / \mathrm{M}$ & 17.2 & -39.6 & -74.1 & 94.9 & 15.4 & -43.0 & -75.9 & 104.5 \\
\hline $7 \mathrm{R}-1,23-25$ & 10.0 & 53.0 & 53.0 & 52.0 & $\mathrm{~B} / \mathrm{M}$ & 76.0 & -22.6 & -17.4 & 100.3 & 78.2 & -31.7 & -17.2 & 106.4 \\
\hline $7 R-2,12-14$ & 5.0 & 323.0 & 323.0 & 47.0 & $\mathrm{~B} / \mathrm{M}$ & 26.1 & -34.4 & -65.3 & 89.3 & 24.7 & -39.1 & -67.2 & 96.5 \\
\hline $9 \mathrm{R}-1,59-61$ & 17.8 & 206.1 & 206.1 & 57.9 & $\mathrm{~B} / \mathrm{A}$ & 88.8 & -58.7 & -15.5 & 131.5 & 116.4 & -71.8 & -6.1 & 155.0 \\
\hline $9 R-1,65-67$ & 8.9 & 206.5 & 206.5 & 57.9 & $\mathrm{~B} / \mathrm{A}$ & 353.3 & -62.5 & -68.8 & 198.1 & 335.9 & -65.1 & -59.4 & 217.8 \\
\hline $9 R-2,91-93$ & 6.4 & 218.6 & 218.6 & 57.9 & $\mathrm{~B} / \mathrm{A}$ & 190.0 & 57.8 & -72.7 & 157.6 & 181.3 & 61.7 & -70.4 & 181.9 \\
\hline $9 \mathrm{R}-2,99-101$ & 10.8 & 33.6 & 33.6 & 47.0 & $\mathrm{~B} / \mathrm{A}$ & 281.0 & -66.9 & -24.5 & 229.2 & 268.5 & -58.2 & -13.3 & 237.8 \\
\hline $12 \mathrm{R}-2,104-106$ & 7.0 & 63.0 & 105.0 & 22.0 & $\mathrm{~F} / \mathrm{M}$ & 16.9 & -55.3 & -70.8 & 139.0 & 8.4 & -59.8 & -71.3 & 164.5 \\
\hline $12 \mathrm{R}-2,114-116$ & 7.0 & 63.0 & 79.0 & 68.0 & $\mathrm{~F} / \mathrm{M}$ & 92.6 & -56.6 & -11.9 & 130.3 & 99.1 & -62.5 & -9.8 & 138.4 \\
\hline $13 R-4,3-5$ & 7.0 & 331.0 & 29.0 & 196.0 & $\mathrm{~F} / \mathrm{M}$ & 122.6 & -57.2 & 8.5 & 142.4 & 126.9 & -50.9 & 15.2 & 139.8 \\
\hline $13 R-4,55-57$ & 2.0 & 298.0 & 64.0 & 196.0 & $\mathrm{~F} / \mathrm{M}$ & 88.3 & -41.8 & -10.8 & 116.4 & 89.1 & -40.1 & -9.6 & 115.5 \\
\hline $15 \mathrm{R}-1,73-75$ & 10.0 & 306.8 & 306.8 & 53.8 & $\mathrm{~B} / \mathrm{A}$ & 26.1 & -10.9 & -59.2 & 63.3 & 24.8 & -19.7 & -62.9 & 69.7 \\
\hline $15 \mathrm{R}-1,104-106$ & 9.0 & 302.0 & 320.0 & 63.0 & $\mathrm{~B} / \mathrm{M}$ & 243.2 & 57.4 & -34.8 & 125.8 & 243.3 & 66.4 & -34.7 & 139.0 \\
\hline $15 \mathrm{R}-1,113-115$ & 7.8 & 320.2 & 320.2 & 53.8 & $\mathrm{~B} / \mathrm{A}$ & 254.5 & 44.4 & -23.2 & 114.3 & 257.8 & 51.6 & -22.1 & 121.6 \\
\hline $15 \mathrm{R}-2,42-44$ & 11.0 & 135.0 & 135.0 & 70.0 & $\mathrm{~B} / \mathrm{M}$ & 45.2 & -48.9 & -49.3 & 113.9 & 38.0 & -58.6 & -54.2 & 130.2 \\
\hline $16 \mathrm{R}-1,78-80$ & 15.0 & 222.0 & 222.0 & 85.0 & $\mathrm{~B} / \mathrm{M}$ & 16.5 & -45.7 & -74.6 & 112.4 & 0.5 & -49.2 & -83.3 & 181.0 \\
\hline $16 \mathrm{R}-1,95-97$ & 4.5 & 222.0 & 222.0 & 85.0 & $\mathrm{~B} / \mathrm{I}$ & 218.0 & 45.5 & -55.5 & 108.8 & 214.3 & 48.4 & -58.8 & 113.3 \\
\hline $16 \mathrm{R}-1,98-100$ & 15.0 & 222.0 & 222.0 & 85.0 & $\mathrm{~B} / \mathrm{M}$ & 215.9 & 39.8 & -57.0 & 100.7 & 203.9 & 48.5 & -67.8 & 115.8 \\
\hline $16 \mathrm{R}-2,124-126$ & 7.0 & 8.0 & 8.0 & 71.0 & $\mathrm{~B} / \mathrm{M}$ & 270.7 & 31.9 & -6.2 & 110.9 & 272.4 & 38.5 & -6.4 & 115.6 \\
\hline $16 \mathrm{R}-2,138-140$ & 5.0 & 11.0 & 11.0 & 71.0 & $\mathrm{~B} / \mathrm{M}$ & 0.7 & -25.1 & -79.8 & 8.6 & 358.4 & -26.7 & -80.6 & 355.1 \\
\hline $16 \mathrm{R}-3,29-31$ & 7.8 & 58.0 & 241.0 & 201.0 & $\mathrm{~F} / \mathrm{M}$ & 5.5 & -42.5 & -84.8 & 109.9 & 10.5 & -37.5 & -80.0 & 83.1 \\
\hline $16 \mathrm{R}-3,53-55$ & 7.0 & 98.0 & 98.0 & 58.0 & $\mathrm{~B} / \mathrm{M}$ & 2.1 & -31.1 & -83.1 & 21.7 & 5.3 & -26.9 & -79.6 & 34.4 \\
\hline $16 \mathrm{R}-5,37-39$ & 11.0 & 322.0 & 322.0 & 348.0 & $\mathrm{~B} / \mathrm{M}$ & 18.8 & -42.0 & -72.8 & 101.5 & 25.3 & -51.1 & -66.1 & 120.9 \\
\hline $16 \mathrm{R}-5,61-63$ & 9.0 & 305.0 & 305.0 & 348.0 & $\mathrm{~B} / \mathrm{M}$ & 16.5 & -15.8 & -68.0 & 53.33 & 18.1 & -23.7 & -69.6 & 65.3 \\
\hline 16R-5, 84-86 & 10.0 & 294.0 & 294.0 & 315.0 & $\mathrm{~B} / \mathrm{M}$ & 255.5 & 24.1 & -18.1 & 101.0 & 258.8 & 18.8 & -14.0 & 99.3 \\
\hline $16 \mathrm{R}-5,92-94$ & 18.0 & 24.0 & 24.0 & 303.0 & $\mathrm{~B} / \mathrm{M}$ & 11.9 & -23.4 & -74.2 & 52.2 & 20.4 & -28.7 & -69.2 & 75.7 \\
\hline $17 \mathrm{R}-2,19-21$ & 9.0 & 221.0 & 221.0 & 243.0 & $\mathrm{~B} / \mathrm{M}$ & 203.4 & 34.3 & -67.7 & 87.4 & 206.7 & 27.2 & -63.3 & 80.0 \\
\hline $17 \mathrm{R}-2,43-45$ & 12.0 & 287.0 & 228.0 & 344.0 & $\mathrm{~F} / \mathrm{M}$ & 302.1 & 21.5 & 23.7 & 119.5 & 301.2 & 9.9 & 26.1 & 113.2 \\
\hline $17 \mathrm{R}-2,68-70$ & 4.0 & 124.0 & 124.0 & 76.0 & $\mathrm{~B} / \mathrm{M}$ & 240.8 & 38.9 & -34.3 & 106.2 & 239.9 & 42.8 & -35.8 & 109.4 \\
\hline $17 \mathrm{R}-2,83-85$ & 7.0 & 90.0 & 90.0 & 76.0 & $\mathrm{~B} / \mathrm{M}$ & 222.4 & 51.5 & -51.7 & 117.6 & 216.6 & 57.1 & -55.6 & 128.0 \\
\hline $17 R-3,135-137$ & 8.0 & 256.0 & 256.0 & 346.0 & $\mathrm{~B} / \mathrm{M}$ & 270.1 & 34.8 & -7.4 & 112.4 & 275.2 & 32.5 & -2.3 & 113.0 \\
\hline $17 R-4,49-51$ & 6.0 & 342.0 & 342.0 & 346.0 & $\mathrm{~B} / \mathrm{M}$ & 228.3 & 35.0 & -45.0 & 99.1 & 232.3 & 37.6 & -41.8 & 102.7 \\
\hline $18 \mathrm{R}-1,105-107$ & 8.0 & 90.0 & 90.0 & 28.0 & $\mathrm{~B} / \mathrm{M}$ & 227.2 & 44.2 & -47.3 & 108.3 & 230.4 & 51.7 & -45.0 & 117.8 \\
\hline $18 \mathrm{R}-2,126-128$ & 6.0 & 329.0 & 329.0 & 7.0 & $\mathrm{~B} / \mathrm{M}$ & 250.5 & 39.1 & -25.7 & 109.0 & 255.2 & 41.6 & -22.0 & 112.3 \\
\hline $19 \mathrm{R}-1,2-4$ & 9.0 & 305.0 & 305.0 & 329.0 & $\mathrm{~B} / \mathrm{M}$ & 260.4 & 30.5 & -15.0 & 106.4 & 264.9 & 26.9 & -10.2 & 105.9 \\
\hline $20 \mathrm{R}-2,12-14$ & 17.0 & 118.0 & 118.0 & 277.0 & $\mathrm{~B} / \mathrm{M}$ & 219.0 & 40.3 & -54.3 & 102.1 & 228.7 & 30.0 & -43.8 & 95.0 \\
\hline $22 \mathrm{R}-3,47-49$ & 13.0 & 72.0 & 72.0 & 126.0 & $\mathrm{~B} / \mathrm{M}$ & 255.7 & 21.5 & -17.4 & 99.6 & 250.8 & 29.4 & -23.5 & 102.4 \\
\hline $22 \mathrm{R}-3,68-70$ & 13.0 & 72.0 & 72.0 & 126.0 & $\mathrm{~B} / \mathrm{M}$ & 254.3 & 42.0 & -22.9 & 112.3 & 243.1 & 49.1 & -33.9 & 116.2 \\
\hline $24 \mathrm{R}-1,96-98$ & 23.0 & 85.0 & 175.0 & 9.0 & $\mathrm{~F} / \mathrm{M}$ & 242.1 & 47.3 & -34.5 & 114.2 & 222.5 & 67.0 & -47.8 & 144.4 \\
\hline $29 \mathrm{R}-2,26-28$ & 6.0 & 39.0 & 39.0 & 199.0 & $\mathrm{~B} / \mathrm{M}$ & 177.1 & -48.7 & 36.9 & 181.6 & 174.1 & -54.2 & 31.7 & 179.0 \\
\hline $32 \mathrm{R}-1,102-104$ & 20.0 & 107.0 & 10.0 & 185.0 & $\mathrm{~F} / \mathrm{M}$ & 343.9 & -45.1 & -75.1 & 258.6 & 331.4 & -32.3 & -62.6 & 281.6 \\
\hline $32 \mathrm{R}-1,128-130$ & 17.0 & 121.0 & 154.0 & 172.0 & $\mathrm{~F} / \mathrm{M}$ & 18.5 & -38.9 & -72.9 & 93.7 & 6.6 & -33.5 & -82.0 & 56.7 \\
\hline $32 \mathrm{R}-1,136-138$ & 17.0 & 121.0 & 154.0 & 172.0 & $\mathrm{~F} / \mathrm{M}$ & 355.9 & -50.5 & -81.3 & 208.6 & 343.1 & -39.1 & -74.3 & 275.9 \\
\hline $32 \mathrm{R}-2,7-9$ & 15.0 & 136.0 & 171.0 & 185.0 & $\mathrm{~F} / \mathrm{M}$ & 29.0 & -44.7 & -63.6 & 107.2 & 16.6 & -38.7 & -74.6 & 92.3 \\
\hline $33 \mathrm{R}-1,11-13$ & 15.0 & 136.0 & 149.0 & 184.0 & $\mathrm{~F} / \mathrm{M}$ & 78.2 & -44.1 & -20.0 & 115.1 & 63.3 & -50.5 & -33.9 & 117.7 \\
\hline $33 \mathrm{R}-1,74-76$ & 13.0 & 226.0 & 33.0 & 184.0 & $\mathrm{~F} / \mathrm{M}$ & 114.3 & -41.6 & 10.6 & 126.8 & 104.9 & -35.8 & 5.0 & 118.8 \\
\hline $33 \mathrm{R}-1,136-138$ & 24.0 & 134.0 & 331.0 & 184.0 & $\mathrm{~F} / \mathrm{M}$ & 35.6 & -37.9 & -57.1 & 98.2 & 19.5 & -31.0 & -70.5 & 78.3 \\
\hline $33 R-2,70-72$ & 9.0 & 131.0 & 18.0 & 184.0 & $\mathrm{~F} / \mathrm{M}$ & 13.3 & -37.3 & -77.4 & 85.8 & 7.8 & -32.7 & -80.8 & 58.9 \\
\hline $34 R-2,3-5$ & 9.0 & 159.0 & 7.0 & 190.0 & $\mathrm{~F} / \mathrm{M}$ & 63.2 & -84.5 & -27.9 & 173.7 & 9.0 & -79.0 & -44.2 & 180.2 \\
\hline $34 \mathrm{R}-2,15-17$ & 18.0 & 149.0 & 178.0 & 5.0 & $\mathrm{~F} / \mathrm{M}$ & 21.9 & -77.9 & -44.4 & 172.8 & 350.6 & -63.0 & -67.5 & 202.5 \\
\hline 35R-1, 107-109 & 26.0 & 307.0 & 307.0 & 110.0 & $\mathrm{~B} / \mathrm{M}$ & 20.9 & -31.1 & -69.3 & 80.0 & 5.9 & -28.0 & -79.8 & 39.1 \\
\hline $35 \mathrm{R}-2,114-116$ & 23.0 & 351.0 & 120.0 & 286.0 & $\mathrm{~F} / \mathrm{M}$ & 338.1 & -28.9 & -67.9 & 291.7 & 332.9 & -51.1 & -64.6 & 249.2 \\
\hline $35 \mathrm{R}-3,124-126$ & 32.0 & 149.0 & 149.0 & 103.0 & $\mathrm{~B} / \mathrm{M}$ & 4.3 & -29.9 & -81.7 & 34.4 & 349.3 & -20.7 & -73.8 & 324.0 \\
\hline $36 \mathrm{R}-1,56-58$ & 25.0 & 94.0 & 94.0 & 133.0 & $\mathrm{~F} / \mathrm{M}$ & 39.1 & -14.8 & -49.3 & 78.2 & 30.6 & -27.8 & -59.9 & 83.7 \\
\hline $36 \mathrm{R}-3,66-68$ & 20.0 & 136.0 & 175.0 & 245.0 & $\mathrm{~F} / \mathrm{M}$ & 338.0 & -47.0 & -69.6 & 256.3 & 332.8 & -28.1 & -63.0 & 287.9 \\
\hline $37 \mathrm{R}-1,76-78$ & 27.1 & 266.1 & 266.1 & 136.0 & $\mathrm{~B} / \mathrm{M}$ & 9.9 & -34.2 & -79.7 & 70.2 & 0.2 & -16.3 & -75.0 & 5.5 \\
\hline $37 R-2,6-8$ & 16.5 & 283.7 & 283.7 & 127.9 & $\mathrm{~B} / \mathrm{A}$ & 359.5 & -49.7 & -82.8 & 188.2 & 348.0 & -38.1 & -78.7 & 282.3 \\
\hline $37 \mathrm{R}-2,33-35$ & 18.8 & 328.4 & 328.4 & 127.9 & $\mathrm{~B} / \mathrm{A}$ & 29.3 & -42.4 & -63.3 & 103.2 & 46.7 & -42.4 & -47.5 & 106.2 \\
\hline $37 R-2,35-37$ & 18.8 & 328.4 & 328.4 & 127.9 & $\mathrm{~B} / \mathrm{A}$ & 27.4 & -44.0 & -65.0 & 105.9 & 45.9 & -44.4 & -48.4 & 108.3 \\
\hline $37 R-2,106-108$ & 25.1 & 237.0 & 237.0 & 127.9 & $\mathrm{~B} / \mathrm{A}$ & 109.6 & -33.6 & 9.6 & 119.6 & 99.4 & -56.8 & -7.0 & 132.5 \\
\hline $37 \mathrm{R}-2,113-115$ & 26.3 & 261.8 & 261.8 & 127.9 & $\mathrm{~B} / \mathrm{A}$ & 13.5 & -35.3 & -76.9 & 80.2 & 34.3 & 41.9 & -58.7 & 103.2 \\
\hline $37 \mathrm{R}-3,48-50$ & 18.7 & 285.1 & 285.1 & 127.9 & $\mathrm{~B} / \mathrm{A}$ & 42.5 & -42.2 & -51.3 & 105.1 & 25.7 & -40.9 & -66.4 & 100.0 \\
\hline $37 \mathrm{R}-3,111-113$ & 30.0 & 271.1 & 271.1 & 127.9 & $\mathrm{~B} / \mathrm{A}$ & 46.6 & -45.8 & -47.9 & 110.1 & 16.7 & -42.3 & -74.7 & 102.3 \\
\hline $37 \mathrm{R}-3,114-116$ & 30.0 & 272.0 & 272.0 & 127.9 & $\mathrm{~B} / \mathrm{A}$ & 53.9 & -46.0 & -41.5 & 111.4 & 21.7 & -45.9 & -70.0 & 110.6 \\
\hline $37 \mathrm{R}-3,119-121$ & 26.0 & 270.0 & 270.0 & 136.0 & $\mathrm{~B} / \mathrm{M}$ & 28.5 & -45.4 & -64.0 & 108.5 & 9.1 & -33.2 & -80.0 & 64.5 \\
\hline $37 \mathrm{R}-3,133-135$ & 29.0 & 270.0 & 270.0 & 127.9 & $\mathrm{~B} / \mathrm{A}$ & 47.5 & -52.0 & -47.4 & 118.2 & 12.2 & -47.6 & -77.8 & 123.3 \\
\hline $37 \mathrm{R}-4,14-16$ & 19.0 & 272.9 & 272.9 & 127.9 & $\mathrm{~B} / \mathrm{A}$ & 33.2 & -50.9 & -59.5 & 117.8 & 112.3 & -45.8 & -78.2 & 116.4 \\
\hline
\end{tabular}


Appendix E (continued).

\begin{tabular}{|c|c|c|c|c|c|c|c|c|c|c|c|c|c|}
\hline \multirow[b]{2}{*}{$\begin{array}{l}\text { Core, section, } \\
\text { interval }(\mathrm{cm})\end{array}$} & \multicolumn{2}{|c|}{ Bedding } & \multirow[b]{2}{*}{$\begin{array}{l}\text { Sample } \\
\text { azimuth } \\
\left({ }^{\circ} \mathrm{E}\right)\end{array}$} & \multirow[b]{2}{*}{$\begin{array}{c}\text { FMS } \\
\text { azimuth } \\
\left(^{\circ} \mathrm{E}\right)\end{array}$} & \multirow[b]{2}{*}{$\begin{array}{c}\text { Orientation } \\
\text { type }\end{array}$} & \multicolumn{4}{|c|}{ VGP A } & \multicolumn{4}{|c|}{ VGP B } \\
\hline & $\begin{array}{l}\text { Dip } \\
\left.\text { ( }{ }^{\circ} \mathrm{D}\right)\end{array}$ & Azimuth & & & & $\begin{array}{l}\text { Dec } \\
\left({ }^{\circ} \mathrm{E}\right)\end{array}$ & $\begin{array}{c}\text { Inc } \\
\left({ }^{\circ} \mathrm{D}\right)\end{array}$ & $\begin{array}{l}\text { Latitude } \\
\left({ }^{\circ} \mathrm{N}\right)\end{array}$ & $\begin{array}{l}\text { Longitude } \\
\left({ }^{\circ} \mathrm{E}\right)\end{array}$ & $\begin{array}{l}\text { Dec } \\
\left({ }^{\circ} \mathrm{E}\right)\end{array}$ & $\begin{array}{l}\text { Inc } \\
\left({ }^{\circ} \mathrm{D}\right)\end{array}$ & $\begin{array}{l}\text { Latitude } \\
\left({ }^{\circ} \mathrm{N}\right)\end{array}$ & $\begin{array}{c}\text { Longitude } \\
\left({ }^{\circ} \mathrm{E}\right)\end{array}$ \\
\hline $37 R-4,33-35$ & 16.1 & 263.1 & 263.1 & 127.9 & $\mathrm{~B} / \mathrm{A}$ & 45.9 & -42.4 & -48.2 & 106.0 & 31.0 & -42.6 & -61.7 & 103.8 \\
\hline $37 R-4,55-57$ & 16.5 & 283.7 & 283.7 & 127.9 & $\mathrm{~B} / \mathrm{A}$ & 50.7 & -40.4 & -43.7 & 104.9 & 36.2 & -42.0 & -56.9 & 103.7 \\
\hline $37 \mathrm{R}-4,89-91$ & 27.2 & 247.4 & 247.4 & 134.0 & $\mathrm{~B} / \mathrm{M}$ & 58.4 & -55.4 & -38.5 & 123.0 & 19.6 & -52.7 & -70.1 & 129.0 \\
\hline $38 \mathrm{R}-1,27-29$ & 21.1 & 95.2 & 95.2 & 124.0 & $\mathrm{~B} / \mathrm{A}$ & 39.5 & -19.8 & -50.1 & 82.2 & 31.7 & -20.4 & -57.2 & 77.1 \\
\hline $38 \mathrm{R}-1,45-47$ & 23.6 & 116.9 & 116.9 & 117.0 & $\mathrm{~B} / \mathrm{M}$ & 5.5 & -18.4 & -75.1 & 26.3 & 0.2 & -8.6 & -70.9 & 5.3 \\
\hline $38 \mathrm{R}-1,57-59$ & 30.5 & 100.0 & 100.0 & 115.0 & $\mathrm{~B} / \mathrm{I}$ & 27.3 & -22.0 & -61.4 & 74.7 & 15.3 & -20.0 & -70.4 & 55.5 \\
\hline $38 \mathrm{R}-2,23-25$ & 16.5 & 103.7 & 103.7 & 117.0 & $\mathrm{~B} / \mathrm{A}$ & 322.9 & -40.0 & -56.0 & 268.2 & 318.6 & -24.9 & -49.5 & 282.0 \\
\hline $38 \mathrm{R}-2,103-105$ & 20.2 & 109.6 & 109.6 & 117.0 & $\mathrm{~B} / \mathrm{A}$ & 18.9 & -42.9 & -72.7 & 103.8 & 2.4 & -37.1 & -86.6 & 45.3 \\
\hline $38 \mathrm{R}-2,121-123$ & 17.0 & 117.7 & 117.7 & 117.0 & $\mathrm{~B} / \mathrm{A}$ & 9.8 & -41.2 & -81.0 & 98.5 & 357.6 & -34.4 & -85.0 & 337.6 \\
\hline $38 \mathrm{R}-2,129-131$ & 16.5 & 114.6 & 114.6 & 117.0 & $\mathrm{~B} / \mathrm{A}$ & 204.4 & -35.1 & 41.1 & 215.9 & 215.9 & -34.2 & 35.2 & 227.5 \\
\hline $38 \mathrm{R}-2,134-136$ & 12.0 & 90.0 & 90.0 & 124.0 & $\mathrm{~B} / \mathrm{M}$ & 43.7 & -40.9 & -50.1 & 103.8 & 33.1 & -41.8 & -59.8 & 102.9 \\
\hline $38 \mathrm{R}-2,145-147$ & 19.9 & 107.0 & 107.0 & 117.0 & $\mathrm{~B} / \mathrm{A}$ & 8.1 & -48.8 & -80.4 & 137.8 & 350.8 & -39.4 & -81.5 & 279.7 \\
\hline $38 \mathrm{R}-3,8-10$ & 23.3 & 99.4 & 99.4 & 134.0 & $\mathrm{~B} / \mathrm{M}$ & 12.3 & -36.7 & -78.3 & 82.8 & 1.6 & -22.5 & -78.3 & 12.4 \\
\hline $38 \mathrm{R}-3,34-36$ & 17.7 & 127.9 & 127.9 & 134.0 & $\mathrm{~B} / \mathrm{I}$ & 338.1 & -41.8 & -70.0 & 268.2 & 333.7 & -25.3 & -63.2 & 292.0 \\
\hline $38 \mathrm{R}-4,21-23$ & 18.7 & 105.1 & 105.1 & 134.0 & $\mathrm{~B} / \mathrm{M}$ & 30.3 & -54.9 & -61.1 & 126.4 & 9.0 & -47.0 & -80.6 & 127.5 \\
\hline $39 \mathrm{R}-1,24-26$ & 13.0 & 276.0 & 90.0 & 120.0 & $\mathrm{~B} / \mathrm{A}$ & 48.2 & -48.1 & -46.7 & 113.1 & 27.8 & -47.4 & -64.5 & 112.3 \\
\hline $39 \mathrm{R}-1,55-57$ & 20.0 & 261.0 & 261.0 & 120.0 & $\mathrm{~B} / \mathrm{A}$ & 34.7 & -43.9 & -58.4 & 106.2 & 16.9 & -39.5 & -74.4 & 94.5 \\
\hline $39 \mathrm{R}-1,71-73$ & 25.0 & 261.0 & 261.0 & 120.0 & $\mathrm{~B} / \mathrm{A}$ & 64.7 & -38.9 & -30.8 & 107.2 & 41.9 & -45.7 & -52.1 & 109.4 \\
\hline $39 \mathrm{R}-1,118-120$ & 29.0 & 298.0 & 298.0 & 120.0 & $\mathrm{~B} / \mathrm{A}$ & 24.1 & -42.7 & -68.0 & 103.3 & 3.6 & -30.0 & -82.0 & 30.4 \\
\hline $39 \mathrm{R}-2,128-130$ & 24.0 & 263.0 & 263.0 & 120.0 & $\mathrm{~B} / \mathrm{A}$ & 62.6 & -53.1 & -34.8 & 120.5 & 27.7 & -56.2 & -62.7 & 130.5 \\
\hline $39 \mathrm{R}-2,137-139$ & 25.0 & 284.0 & 284.0 & 120.0 & $\mathrm{~B} / \mathrm{A}$ & 64.8 & -49.4 & -32.5 & 116.8 & 31.4 & -54.1 & -60.5 & 124.3 \\
\hline $40 \mathrm{R}-1,50-52$ & 11.0 & 225.0 & 225.0 & 134.0 & $\mathrm{~B} / \mathrm{M}$ & 80.6 & -20.8 & -12.8 & 101.0 & 76.6 & -27.1 & -17.7 & 103.1 \\
\hline $40 \mathrm{R}-1,86-88$ & 25.0 & 257.0 & 257.0 & 126.0 & $\mathrm{~B} / \mathrm{M}$ & 36.3 & -46.0 & -57.1 & 109.5 & 12.0 & -40.5 & -78.9 & 95.9 \\
\hline $40 \mathrm{R}-1,97-99$ & 26.0 & 290.0 & 290.0 & 126.0 & $\mathrm{~B} / \mathrm{A}$ & 166.2 & -40.5 & 41.6 & 167.6 & 183.1 & -64.5 & 20.2 & 187.0 \\
\hline $40 \mathrm{R}-1,120-122$ & 15.0 & 284.0 & 284.0 & 125.0 & $\mathrm{~B} / \mathrm{M}$ & 28.3 & -57.9 & -61.5 & 133.6 & 6.5 & -53.1 & -78.2 & 157.2 \\
\hline $40 \mathrm{R}-2,49-51$ & 29.0 & 259.0 & 259.0 & 124.0 & $\mathrm{~B} / \mathrm{M}$ & 54.6 & -39.8 & -40.0 & 105.3 & 27.6 & -43.6 & -64.8 & 105.2 \\
\hline $40 \mathrm{R}-3,11-13$ & 34.0 & 262.0 & 262.0 & 124.0 & $\mathrm{~B} / \mathrm{M}$ & 57.7 & -34.7 & -36.4 & 101.9 & 30.4 & -41.0 & -62.2 & 101.2 \\
\hline $40 \mathrm{R}-3,113-115$ & 32.0 & 260.0 & 260.0 & 126.0 & $\mathrm{~B} / \mathrm{A}$ & 67.8 & -32.3 & -26.8 & 103.3 & 46.4 & -32.7 & -46.4 & 96.4 \\
\hline $40 \mathrm{R}-3,131-133$ & 26.0 & 290.0 & 290.0 & 126.0 & $\mathrm{~B} / \mathrm{A}$ & 112.8 & -21.7 & 15.8 & 114.7 & 101.9 & -42.8 & 0.3 & 122.1 \\
\hline $40 \mathrm{R}-4,31-33$ & 35.0 & 267.0 & 267.0 & 126.0 & $\mathrm{~B} / \mathrm{A}$ & 65.7 & -42.5 & -30.6 & 110.5 & 34.6 & -38.4 & -58.1 & 98.5 \\
\hline $40 \mathrm{R}-4,56-58$ & 31.0 & 283.0 & 283.0 & 126.0 & $\mathrm{~B} / \mathrm{M}$ & 76.5 & -58.3 & -24.6 & 128.5 & 16.0 & -64.8 & -63.3 & 159.8 \\
\hline $41 \mathrm{R}-1,40-42$ & 33.0 & 323.0 & 323.0 & 163.0 & $\mathrm{~B} / \mathrm{M}$ & 59.7 & -54.8 & -37.4 & 122.3 & 28.2 & -37.8 & -63.9 & 95.5 \\
\hline $41 \mathrm{R}-2,29-31$ & 33.0 & 116.0 & 116.0 & 161.0 & $\mathrm{~B} / \mathrm{M}$ & 17.1 & -56.4 & -70.0 & 141.4 & 2.5 & -27.1 & -80.7 & 19.9 \\
\hline $41 R-3,24-26$ & 37.0 & 313.0 & 313.0 & 147.0 & $\mathrm{~B} / \mathrm{M}$ & 36.6 & -57.2 & -55.6 & 128.2 & 4.7 & -33.9 & -83.5 & 48.1 \\
\hline $42 \mathrm{R}-4,125-127$ & 12.0 & 329.0 & 329.0 & 83.0 & $\mathrm{~B} / \mathrm{M}$ & 65.7 & -41.8 & -30.4 & 110.0 & 61.3 & -53.1 & -35.9 & 120.3 \\
\hline $43 \mathrm{R}-1,45-47$ & 14.0 & 262.0 & 262.0 & 217.0 & $\mathrm{~B} / \mathrm{M}$ & 14.6 & -56.9 & -71.1 & 146.5 & 20.3 & -43.7 & -71.4 & 105.6 \\
\hline $43 \mathrm{R}-1,130-132$ & 13.0 & 217.0 & 342.0 & 15.0 & $\mathrm{~F} / \mathrm{M}$ & 25.6 & -28.1 & 44.2 & 220.3 & 23.7 & -40.8 & -68.3 & 99.4 \\
\hline $44 \mathrm{R}-2,16-18$ & 45.0 & 123.0 & 123.0 & 93.0 & $\mathrm{~B} / \mathrm{M}$ & 330.6 & -65.7 & -56.1 & 220.9 & 296.5 & -29.2 & -30.1 & 269.9 \\
\hline $44 \mathrm{R}-2,9-11$ & 53.0 & 64.0 & 64.0 & 105.0 & $\mathrm{~B} / \mathrm{M}$ & 73.4 & -38.0 & -22.9 & 109.1 & 3.0 & -65.0 & -66.2 & 179.6 \\
\hline
\end{tabular}

Note: Bedding = dip (in degrees below horizontal) and dip direction (positive clockwise) in sample coordinates (i.e., relative to core liner); Sample azimuth $=$ azimuth (positive clockwise) of feature used for reorientation (bedding plane or fault-dip direction), in core coordinates; FMS azimuth = feature azimuth from Formation MicroScanner log as follows: $\mathrm{B}=$ bedding plane, $\mathrm{F}=$ fault, $\mathrm{M}=$ matched to feature in FMS $\log , \mathrm{A}=$ average dip direction, $\mathrm{I}=$ inferred from adjacent piece. VGP A, "Dec" and "Inc", "Latitude". "Longitude" for VGPA = paleomagnetic declination and inclination, paleomagnetic pole latitude and longitude, from sample magnetic vectors reoriented with individual picks of FMS log feature azimuth (where available) but with no correction for bed dip. VGP B = VGP A, but with correction for sample bed-dip. 